\title{
CARACTERÍSTICAS MORFOLÓGICAS DA CUTÍCULA FOLIAR E EFEITOS DE ADJUVANTES NO CONTROLE QUIMICO DE TRÊS ESPÉCIES DE GUANXUMAS.
}

\author{
LÚCIA HELENA DE BARROS ALBERT \\ Engenheira Agrônoma
}

Orientador: Prof. Dr. RICARDO VICTORIA FILHO

Dissertação apresentada à Escola Superior de Agricultura "Luiz de Queiroz”, Universidade de São Paulo, para obtenção do título de Mestre em Agronomia, Área de Concentração: Fitotecnia.

PIRACICABA

Estado de São Paulo - Brasil

Maio - 2000 


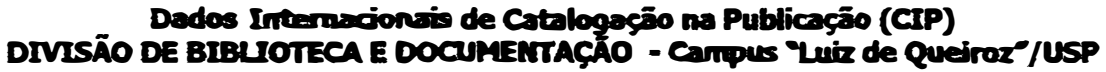

Albert, Lúcia Helena de Barros

Características morfológicas da cutícula foliar e efeitos de adjuvantes no

controle químico de três espécies de guanxumas / Lúcia Helena de Barros

Albert. - - Piracicaba, 2000.

94 p. : il.

Dissertação (mestrado) - - Escola Superior de Agricultura Luiz de Queiroz, 2000.

Bibliografia.

1. Controle químico 2. Cutícula vegetal 3. Herbicida 4. Guanxuma 5.

Microscopia eletrônica de varredura 6. Morfologia vegetal 7. Planta daninha 1. Título

CDD 632.58

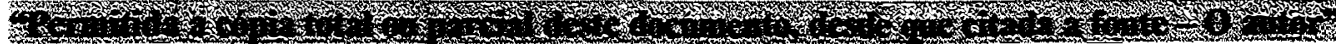


"Esse trabalho é inteiramente dedicado ao meu pai, meu grande amigo e também colega de profissão, Carlos Antônio Albert, que me ensinou tantos valores bons da vida, entre eles o gosto pelo estudo e a importância de sabermos recomeçar."

Ao meu marido, Luiz
Gonzaga e ao meu filho,
Francisco, que são a minha
força e minha luz,
OFEREÇO.


'Nada te perturbe. Nada te espante. Tudo passa. Só Deus não muda. A paciência tudo alcança. Quem a Deus tem nada lhe falta - Só Deus basta."

Santa Teresa d'Ávila

" De fato é necessário certa sabedoria para compreender que a opinião que defendemos é somente nossa hipótese preferida, necessariamente imperfeita, provavelmente temporária e que só os tolos transmitem como certeza ou verdade" Milan Kundera 


\section{Agradecimentos}

Aos professores do Departamento de Produção Vegetal da Escola Superior de Agricultura "Luiz de Queiroz" - USP, especialmente ao meu orientador Prof. Dr. Ricardo Victoria Filho e ao Prof. Dr. Pedro J. Christoffoleti, pelas valiosas sugestões que muito contribuíram para o desenvolvimento e aperfeiçoamento desse trabalho.

Ao Núcleo de Apoio à Pesquisa em Microscopia Eletrônica aplicada à pesquisa Agropecuária (NAP/MEPA)-ESALQ, em especial ao Prof. E. W. Kitajima pelos cursos ministrados e pela indispensável ajuda da técnica de laboratório Silvania Machado em todos os momentos.

À prof . Beatriz Appezzato da Glória e à técnica Marli Kosue M. Soares do Departamento de Botânica da ESALQ por vários ensinamentos tão importantes.

À Eng ${ }^{a}$. Agr ${ }^{a}$. Helena Maria C. P. Chamma, técnica de laboratório de sementes da ESALQ, pela ajuda nos testes de germinação e quebra de dormência das sementes.

Aos funcionários do Departamento de Produção Vegetal da Escola Superior de Agricultura "Luiz de Queiroz" - USP, em especial ao Luiz, Ony, Cidão, Cido, Bete, Silvia, Célia e D. Helena.

Ao Dr. Kurt Kissmann da BASF e aos colegas da ZENECA que me ajudaram com preciosas informações.

Às minhas grandes amigas, Marluce G. Cortez, Alessandra C. B. de A. Monteiro, Liliane Stipp e Denise Garcia de Santana por tantas contribuições e pelos momentos de grande alegria.

Aos meus pais, Carlos e Sônia, que não mediram esforços para que eu alcançasse meus objetivos e aos meus irmãos, Ana, Silvia e Henrique que são a alegria da minha vida. 


\section{SUMÁRIO}

Página

LISTA DE FIGURAS.................................................................... iii

LISTA DE TABELAS .................................................................. v

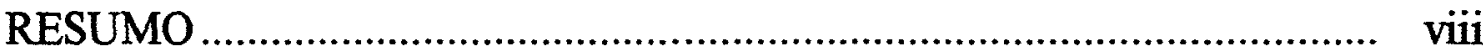

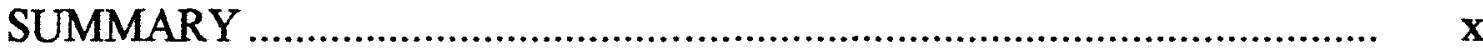

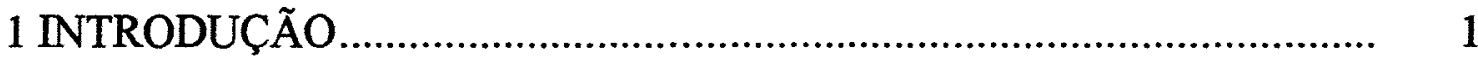

2 REVISÃO DE LITERATURA ........................................................

2.1 Características da superficie foliar .................................................. 3

2.2 Interação entre o herbicida e a superficie foliar ...................................... 7

2.3 Influência de adjuvantes na superficie foliar ......................................... 13

2.3.1 Características e tipos de adjuvantes ................................................. 13

2.3.2 Efeitos de adjuvantes na superfície foliar ........................................... 18

2.4 Herbicidas mimetizadores de auxina. ............................................... 21

3 MATERIAL E MÉTODOS ........................................................... 26

3.1 Descrição das espécies de guanxumas ( Sida spp) 26

3.2 Características morfológicas da cutícula foliar de três espécies de guanxuma............................................................. 28

3.2.1 Determinação da espessura da cutícula.............................................. 28

3.2.1.1 Preparação do material ................................................................. 29

3.2.1.2 Leitura em microscópio de luz ................................................... 29 
3.2.2 Caracterização da superficie foliar com o uso da Microscopia Eletrônica de Varredura (MEV) ..................................................... $\quad 30$

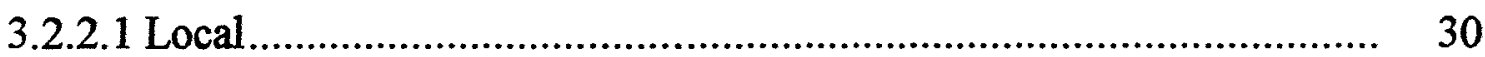

3.2.2.2 Preparação do material: amostras biológicas ................................. 30

3.2.2.3 Observação em microscópio eletrônico .......................................... 33

3.3 Controle químico das espécies de guanxuma (Sida spp) ........................ 33

3.3.1 Teste preliminar de germinação ..................................................... 33

3.3.2 Local do experimento .............................................................. 34

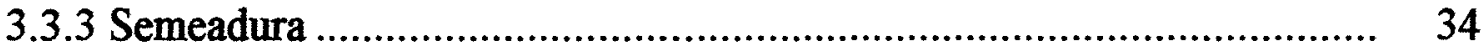

3.3.4 Delineamento experimental e tratamentos ......................................... 35

3.3.5 Herbicidas e adjuvantes utilizados.................................................. 37

3.3.6 Aplicação dos tratamentos............................................................... 38

3.3.7 Avaliação do experimento ............................................................... 38

3.3.8 Análise estatística ..................................................................... 39

4 RESULTADOS E DISCUSSÃO ................................................. 40

4.1 Características morfológicas da cutícula foliar de três espécies de guanxuma................................................................. 40

4.1.1 Determinação da espessura da cutícula............................................. 40

4.1.2 Caracterização da superfície foliar com o uso da Microscopia

Eletrônica de Varredura (MEV).......................................................... 40

4.2 Controle químico das espécies de guanxuma (Sida spp) ...................... 50

4.2.1 Efeito de adjuvantes no controle da espécie Sida rhombifolia ........... 50

4.2.2 Efeito de adjuvantes no controle da espécie Sida glaziovii ................ 59

4.2.3 Efeito de adjuvantes no controle da espécie Sida cordifolia ............... 69

5 CONCLUSÕES ...................................................................... 80

6 REFERÊNCIAS BIBLIOGRÁFICAS .......................................... 82

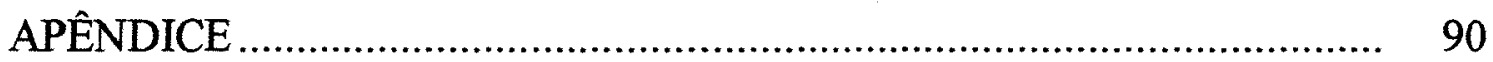




\section{LISTA DE FIGURAS}

Página

1 Esquema de duas respostas resultantes de ligação entre a auxina ou herbicida hormonal ao receptor de auxinas.

2 Superficie adaxial da folha de Sida rhombifolia. Vista geral da epiderme. Escala: $200 \mathrm{X} / 50 \mu \mathrm{m}$.

3 Superficie adaxial da folha de Sida glaziovii. Vista geral da epiderme. Escala: $200 \mathrm{X} / 50 \mu \mathrm{m}$.

4 Superficie adaxial da folha de Sida cordifolia. Vista geral da epiderme. Escala: $200 \mathrm{X} / 50 \mu \mathrm{m}$.

5 Superficie adaxial da folha de Sida cordifolia. Cutícula plana. Escala: $1000 \mathrm{X} / 10 \mu \mathrm{m}$

6 Superficie adaxial da folha de Sida glaziovii. Paredes anticlinais sinuosas. Tricoma glandular e estômato anomocítico. Escala: $1000 \mathrm{X} / 10 \mu \mathrm{m}$

7 Superficie adaxial da folha de Sida rhombifolia. Paredes anticlinais sinuosas. Tricoma estelar e estômato anomocítico. Escala: $1000 \mathrm{X} / 10 \mu \mathrm{m}$. 
8 Superficie adaxial da folha de Sida cordifolia. Vista geral da epiderme. Escala: $200 \mathrm{X} / 5 \mu \mathrm{m}$.

9 Superficie adaxial da folha de Sida cordifolia. Detalhe do estômato e da superfície plana. Escala: $2000 \mathrm{X} / 5 \mu \mathrm{m}$.

10 Superficie adaxial da folha de Sida rhombifolia.

Detalhe do estômato e da cutícula estriada. Escala: $2000 \mathrm{X} / 5 \mu \mathrm{m}$

11 Superficie adaxial da folha de Sida glaziovii. Detalhe do estômato e da cutícula estriada. Escala: $2000 \mathrm{X} / 5 \mu \mathrm{m}$.

12 Superficie abaxial da folha de Sida rhombifolia. Vista geral da epiderme. Detalhe dos tricomas. Escala: $200 \mathrm{X} / 50 \mu \mathrm{m}$.

13 Superficie abaxial da folha de Sida glaziovii. Vista geral da epiderme. Detalhe dos tricomas. Escala: $200 \mathrm{X} / 50 \mu \mathrm{m}$.

14 Superficie abaxial da folha de Sida cordifolia. Vista geral da epiderme. Detalhe dos tricomas. Escala: $200 \mathrm{X} / 50 \mu \mathrm{m}$.

15 Superficie abaxial da folha de Sida glaziovii. Detalhe de tricoma glandular e estelar. Escala: $1000 \mathrm{X} / 10 \mu \mathrm{m}$

16 Superficie adaxial da folha de Sida cordifolia. Detalhe de tricoma simples e glandular. Escala: $500 \mathrm{X} / 20 \mu$ 


\section{LISTA DE TABELAS}

Página

1 Resultados da análise química do solo usado no experimento com guanxumas em casa-de-vegetação, Piracicaba, 1999

2 Tratamentos utilizados em casa-de-vegetação com respectivas doses. Piracicaba 1999.

3 Notas de fitotoxicidade dos tratamentos aplicados em Sida rhombifolia

4 Médias da primeira avaliação (7 DAA) da espécie Sida rhombifolia considerando o esquema fatorial

5 Médias da segunda avaliação (14 DAA) da espécie Sida rhombifolia considerando o esquema fatorial.

6 Médias da terceira avaliação (28 DAA) da espécie Sida rhombifolia considerando o esquema fatorial.................................

7 Médias da quarta avaliação (56 DAA) da espécie Sida rhombifolia considerando o esquema fatorial

8 Médias de pesos ( $\mathrm{g}$ ) da biomassa recém colhida e seca aos 56 DAA da espécie Sida rhombifolia.

9 Biomassa recém colhida (g) (56 DAA) da espécie Sida rhombifolia..... 
10 Biomassa seca (g) (56 DAA) da espécie Sida rhombifolia.

11 Notas de fitotoxicidade dos tratamentos aplicados em Sida glaziovii.

12 Médias da primeira avaliação (7 DAA) da espécie Sida glaziovii considerando o esquema fatorial

13 Médias da segunda avaliação (14 DAA) da espécie Sida glaziovii considerando o esquema fatorial.

14 Médias da terceira avaliação (28 DAA) da espécie Sida glaziovii considerando o esquema fatorial. Piracicaba, 1999.

15 Médias da quarta avaliação (56 DAA) da espécie Sida glaziovii considerando o esquema fatorial. Piracicaba, 1999.

16 Médias de pesos ( $\mathrm{g}$ ) da biomassa recém colhida e seca aos 56 DAA da espécie Sida glaziovii. Piracicaba, 1999.

17 Avaliação da biomassa recém colhida (g) (56 DAA) daespécie Sida glaziovii. Piracicaba, 1999.

18 Avaliação da biomassa seca (g) (56 DAA) da espécie Sida glaziovii. Piracicaba, 1999.

19 Notas de fitotoxicidade dos tratamentos aplicados em Sida cordifolia. Piracicaba 1999. 
20 Médias da primeira avaliação (7 DAA) da espécie Sida cordifolia considerando o esquema fatorial. Piracicaba, 1999

21 Médias da segunda avaliação (14 DAA) da espécie Sida cordifolia considerando o esquema fatorial. Piracicaba, 1999.

22 Médias da terceira avaliação (28 DAA) da espécie Sida cordifolia considerando o esquema fatorial. Piracicaba, 1999.

23 Médias da quarta avaliação (56 DAA) da espécie Sida cordifolia considerando o esquema fatorial. Piracicaba, 1999

24 Médias de pesos ( $\mathrm{g}$ ) da biomassa recém colhida e seca aos 56 DAA da espécie Sida cordifolia. Piracicaba, 1999

25 Avaliação biomassa recém colhida (g) (56 DAA) da espécie Sida cordifolia. Piracicaba, 1999

26 Avaliação biomassa seca (g) (56 DAA) da espécie Sida cordifolia. Piracicaba, 1999 


\title{
CARACTERÍSTICAS MORFOLÓGICAS DA CUTÍCULA FOLIAR E EFEITOS DE ADJUVANTES NO CONTROLE QUÍMICO DE ESPÉCIES DE GUANXUMAS (Sida Spp).
}

\author{
Autora: LÚCIA HELENA B. ALBERT \\ Orientador: Prof. Dr. RICARDO VICTORIA FILHO
}

\section{RESUMO}

A eficácia dos herbicidas aplicados à folha é influenciada pela morfologia e características fisico-químicas da superficie foliar que recebe a calda contendo o herbicida. A topografia da superficie foliar, a espessura da cutícula, o grau e o tipo da formação da cera epicuticular e a presença, tipo e distribuição de tricomas, são características que influenciam na distribuição da calda herbicídica, pulverizada sobre a superficie foliar e consequentemente na eficácia do controle da planta daninha. As propriedades químicas e estruturais da cutícula foliar das plantas tem importante papel na deposição e penetração de substâncias orgânicas. $\mathrm{O}$ aumento da eficácia de herbicidas de absorção foliar em função do uso de adjuvantes, tem sido muitas vezes atribuído, à redução da tensão superficial entre calda pulverizada e superficie da planta, aumento na molhabilidade, na cobertura superficial e penetração cuticular. Diante desses fatos, o presente trabalho visou conhecer morfologicamente a superficie foliar de 
três espécies da planta daninha guanxuma (Sida rhombifolia, Sida glaziovii e Sida cordifolia) e o comportamento de alguns herbicidas em mistura com diferentes adjuvantes na eficácia de seus controles. Os herbicidas utilizados foram o 2,4-D + picloram (240 g.L $\mathrm{L}^{-1}, 64$ g.L $\left.\mathrm{L}^{-1}\right)$, o 2,4-D + picloram $\left(120\right.$ g.L $\mathrm{L}^{-1}, 40$ g.L $\left.\mathrm{L}^{-1}\right)$ e o fluroxipir + picloram, todos do grupo dos fenoxiacéticos e os adjuvantes utilizados foram os surfactantes Agral e Silwet L-77 e o óleo mineral Joint. Foram conduzidos dois experimentos, sendo o primeiro em casa-de-vegetação do Departamento de Produção Vegetal e segundo no Núcleo de Apoio à Pesquisa em Microscopia Eletrônica aplicada à pesquisa Agropecuária (NAP/MEPA), ambos instalados na Escola Superior de Agricultura "Luiz de Queiroz", Universidade de São Paulo, Piracicaba-SP, Brasil. Verificou-se que no experimento com o uso de microscopia eletrônica de varredura, a espécie Sida rhombifolia foi a que apresentou maior quantidade de ceras epicuticulares estriadas enquanto que a espécie Sida cordifolia foi a que apresentou a cutícula mais plana e lisa. A espécie Sida glaziovii foi a que apresentou maior quantidade de tricomas na superficie superior (adaxial). Todas as espécies analisadas apresentaram estômatos em ambas as faces e do tipo anomocítico. No experimento de controle químico não foi obtido interação significativa entre os fatores estudados, herbicidas e adjuvantes, mostrando que o efeito entre os herbicidas foi independente dos adjuvantes e vice-versa. $\mathrm{Na}$ média o herbicida que apresentou maiores notas de fitotoxicidade foi o herbicida fluroxipir + picloran na dose de $1,5 \mathrm{~L} \mathrm{ha}^{-1}$ de produto comercial nas três espécies. 


\title{
MORPHOLOGIC CHARACTERISTICS OF FOLIAR CUTICLE AND EFFECTS OF ADJUVANTS IN THE CHEMICAL CONTROL OF PRICKLY SIDA SPECIES (Sida spp).
}

\author{
Author: LÚCIA HELENA ALBERT \\ Adviser: RICARDO VICTORIA FILHO
}

\section{SUMMARY}

The efficacy of foliar applied herbicides is influenced by the morphological and physical-chemical characteristics of the leaf surface that receives the herbicide spray solution. The topography of the leaf surface, thickness of the cuticle, and the degree and type of epicuticle wax and the presence and type of tricomes, are characteristics that influence the distribution of the herbicide spray solution on the leaf surface and so the efficacy of weed control. The chemical properties of the foliar cuticle structure have important role in the deposition and penetration of organic substances. The improvement of foliar herbicide efficacy as a function of the use of adjuvants, has been attributed to the reduction of the superficial tension between the spray solution and leaf surface, increase of wettability, and superficial cover and cuticular penetration. 
According to this information, a research project was developed in order to increase the knowledge on the morphologic characteristics of three foliar surface of prickly sida (Sida rhombifolia, Sida glaziovii and Sida cordifolia) and the behavior of certain herbicides in mixture with different adjuvants in the efficacy and their control. The herbicide treatments used were 2,4-D + picloran (240 g. $\left.\mathrm{L}^{-1}, 64 \mathrm{~g} . \mathrm{L}^{-1}\right)$, and 2,4-D + picloran (120 g. $\left.\mathrm{L}^{-1}, 40 \mathrm{~g} . \mathrm{L}^{-1}\right)$ and fluroxypir + picloran, all herbicides belonging to phenoxyacetic acids herbicide group and the adjuvants used were the surfactants Agral and Silwet L-77 and the mineral oil Joint. Two experiments were conducted, being one in greenhouse of the Plant Production Department and the second in the Electronic Microscopic Center Applied to Agriculture (NAP/MEPA), both at Escola Superior de Agricultura "Luiz de Queiroz", Universidade of São Paulo, Piracicaba-SP, Brazil. It was observed in the experiment where electronic microscopy techniques was used, that the species Sida rhombifolia presented higher amount of epicuticle striped wax while the species Sida cordifolia presented the cuticle flat and smooth. The species Sida glaziovii was the one that showed higher amount of tricomes on the adaxial foliar surface. All the species analyzed presents stomates in both surface of the leaves type anomocytic. In the experiment of chemical control it was not obtained significant interaction between the studied factors, herbicides and adjuvants, showing independence of these factors among themselves. The herbicide that showed best control was fluroxypir + picloran at $1.5{\mathrm{~L} . h a^{-1}}^{-1}$ of commercial product on the three species. 


\section{INTRODUÇÃO}

A ação fitotóxica dos herbicidas é de um modo geral, dependente de constituintes da calda de pulverização que não fazem parte do ingrediente ativo do herbicida e que melhoram a sua eficácia. A atividade do herbicida, de acordo com Harker (1992) é, muitas vezes, melhorada por adjuvantes os quais não estão contidos no produto formulado herbicida. Como os adjuvantes podem melhorar a eficácia do herbicida eles possibilitam a redução de suas doses mantendo níveis adequados de controle das plantas daninhas. Dessa forma, além do decréscimo nas doses e consequentemente nos custos, haveria um menor impacto ambiental destes produtos.

Dentre os parâmetros muitas vezes negligenciado em toda seqüência de eventos que conduz ao controle eficaz das plantas daninhas em condições de aplicação em pós - emergência destacam-se a distribuição da calda e a forma física da molécula de herbicida na superficie foliar depois da aplicação e antes da sua absorção. Conforme citado por Hess \& Falk (1990), o estudo de um herbicida nas superficies foliares depois de uma aplicação em pós - emergência, usualmente não é feito durante nenhuma fase de pesquisa e desenvolvimento do produto, pois as metodologias de estudo não são ainda usualmente empregadas pelos pesquisadores de forma rotineira.

Um herbicida que não alcança o local de ação nas plantas não contribui para a eficácia do produto; no entanto, o nível de tecnologia atualmente 
empregado nas aplicações de herbicidas não é suficiente para colocar todo o herbicida aplicado no alvo. Assim, o estudo sobre a melhor intercepção, retenção e absorção dos herbicidas aplicados em pós - emergência pelas plantas é muito importante. (Devine et al, 1990).

Para uma boa distribuição da calda do herbicida na superficie foliar da planta, deve-se levar em consideração os fatores que influenciam essa distribuição, como a morfologia da planta e o uso de adjuvantes.

Segundo Kirkwod (1993), os mecanismos pelos quais os adjuvantes produzem efeitos benéficos na ação dos herbicidas aplicados em pós-emergência, podem envolver fenômenos tanto na superficie foliar, na absorção pelos tecidos, como na penetração via cutícula e estômatos. Recentes estudos têm mostrado a importância da dinâmica da tensão superficial como um fator de controle nos fenômenos citados acima, através de ferramentas que possam ser usadas para o estudo do comportamento do herbicida após sua deposição na superfície foliar.

A microestrutura da superficie cuticular tem uma considerável influência na sua molhabilidade e desta forma na deposição e cobertura da calda de pulverização e é influenciada grandemente pela topografia das características subjacentes da epiderme. Isto pode ser revelado claramente pelo exame com o microscópio eletrônico de varredura (Holloway, 1993).

O objetivo desse trabalho foi conhecer a morfologia externa e a espessura da cutícula foliar de três espécies da planta daninha, Sida rhombifolia, Sida glaziovii e Sida cordifolia; e estudar a eficácia de três herbicidas em mistura com diferentes adjuvantes. 


\section{REVISÃO DE LITERATURA}

\subsection{Características da superficie foliar}

A camada que cobre as células epidérmicas da folha pode ser distinguida de todas as outras paredes celulares pela presença de uma camada contínua e fina predominante de material lipídico depositado em sua superficie externa. Esta camada extra celular é a membrana cuticular ou cutícula que serve como interface entre a planta e o ambiente, tornando-se assim protetora e controladora de perdas de água vinda dos tecidos da planta. A cutícula é também a primeira barreira à entrada de produtos químicos aplicados via foliar. Desta forma, muitos estudos têm sido feitos, sobre sua natureza e os fatores que influenciam a sua permeabilidade (Bucovak et al., 1990 ; Holloway, 1982).

A membrana cuticular (MC) ou cutícula, usada em seu sentido mais amplo, pode ser definida, de acordo com Devine et al. (1993) e Holloway (1982), pela sua posição anatômica ou sua natureza química. Quimicamente ela é sempre caracterizada por dois grupos específicos de substâncias lipídicas: cutinas, as quais constituem uma estrutura de suporte da membrana; e ceras depositadas na superficie externa, chamadas de ceras epicutilares e também firmemente dispersas 
no interior da matriz de cutina, logo abaixo da superficie, chamada de ceras cuticulares.

A cutícula, de acordo com análises químicas procedidas por inúmeros pesquisadores, é constituída quimicamente por quatro componentes essenciais: cutina, ceras, pectinas e celulose (Camargo \& Silva, 1975).

As ceras são compostas de longas cadeias hidrocarbonatadas lineares ou ramificadas de alcanos, álcoois, cetonas e aldeídos graxos, ácidos graxos saturados e insaturados, e ésteres graxos com comprimento de cadeia variando em 21 e 35 átomos de carbono, formando uma camada praticamente contínua na superficie da cutícula. A composição das ceras é a principal determinante da molhabilidade da cutícula. As estruturas de cera podem ser amorfas ou apresentar forma de grânulos, bastonetes, placas, crostas ou agregados (Velini \& Trindade, 1992).

As ceras epicuticulares, pertencentes à primeira camada, podem ser amorfas ou depositadas em variáveis formas fisicas, sendo que em algumas espécies elas formam uma camada plana, achatada, enquanto que em outras elas são prensadas na forma de lâminas ou cristais com vasta extensão em termos de tamanho e forma. Estes cristais podem ter estruturas definidas como cristalinas ou semi cristalinas (Devine, 1993; Baker, 1982). Essas diferenças nos padrões cuticulares podem, como ressaltado em Cutter (1986), ser taxonomicamente úteis em termos genéricos e mesmo entre espécies. A cera pode ser depositada em flocos grandes ou pequenos, em grânulos, hastes, tubos ou lâminas, que podem estar esculpidos em cumes ou outras formas. As condições sob as quais as plantas se desenvolvem, podem afetar a forma da cera. As amostras de cera variam nas diferentes espécies e em alguma extensão dentro da mesma espécie sob condições diferentes. A formação da cera aparentemente começa num estágio inicial do desenvolvimento da folha e persiste até o final; as projeções parecem alcançar 
uma densidade e um comprimento bastante uniformes e então permanecem relativamente inalteradas.

De acordo com Camargo \& Silva (1975) e Velini \& Trindade (1992), a cutina, o segundo componente, apresenta estrutura bastante simples. É composta de ácidos graxos hidroxilados e ácidos graxos unidos por ligações éster. São verificados ácidos tanto mono quanto dicarboxilicos, sendo predominante as cadeias com 16 a 18 átomos de carbono. Boa parte dos grupos polares permanece livre, fazendo com que a cutina seja mais hidrofilica do que as ceras cuticulares. Outro componente da cutícula é a pectina, composta principalmente de polímeros polissacarídicos, ricos em ácido urânico, e apresenta-se na forma de filamentos dispersos na matriz de cutina. São substâncias altamente hidrófilas, e se encontram em maior quantidade na região mais profunda da cutícula, em contato com as paredes externas das células epidérmicas. Estas paredes são embebidas pelo material pectináceo tendo pois, intensificadas as suas propriedades hidrofilicas. Embora a maior concentração das pectinas se localize junto às células epidérmicas, na parte mais profundas da cutícula, as pectinas abrangem toda a espessura da cutícula, constituindo o próprio substrato para o desenvolvimento das estruturas da cutina e das ceras. As pectinas encontram-se na cutícula em um estado de gel coloidal, com grande capacidade de absorção de água. Quando há boa disponibilidade de água para a cutícula, as pectinas a absorvem e aumentam de volume. No caso contrário, elas perdem água, diminuindo de volume, influenciando assim significativamente a espessura e a permeabilidade da cutícula à substâncias hidrossolúveis. A celulose encontra-se, na cutícula, na forma de lamelas impregnadas de cutina, dispostas em posição periclinal e distribuídas em toda a espessura da cutícula. A celulose, como se sabe, é altamente hidrófila ao passo que a cutina é semi hidrófoba. 
Como a cutícula tem componentes hidrófobos (cera), semi hidrófobos (cutina) e hidrófilos (pectinas e celulose), ela permite, então, a penetração das substâncias predominantemente polares através das pectinas e das não polares ou predominantemente não polares através das ceras e da cutina. A distribuição de constituintes químicos através da membrana cuticular, determinam que a cutícula não é uma camada homogênea e a superficie externa é altamente lipofilica se tornando mais hidrofilica no interior da mesma (Devine et al., 1993).

Na maioria das plantas, a membrana cuticular não é nem estruturalmente nem quimicamente homogênea mas, composta por um número de camadas, cada qual definida em virtude de sua posição ou constituição química. Desta forma, já que em número, espessura e demarcação essas camadas variam consideravelmente de espécie para espécie e também estágio de desenvolvimento da planta, é sempre inviável apresentar um esquema simples generalizado de construção da membrana cuticular. Normalmente, as superficies foliares não são planas, mas consistem de áreas com elevações e depressões podendo incluir tricomas, estômatos, glândulas e células guardas (Holloway, 1982).

Algumas superficies foliares, não têm características estruturais de ceras epicuticulares, enquanto outras, como por exemplo as Gramíneas e Brassicas, têm depósitos bem desenvolvidos dessas ceras. As folhas de plantas também variam nas proporções de tricomas e desenvolvimento de glândulas. Abutilon theophrasti, por exemplo, tem tricomas simples e complexo, enquanto a erva-desanta-maria (Chenopodium album) têm glândulas na superficie epidermal que se tornam tão abundante, que a superfície é quase oclusa (Hess \& Falk, 1990).

Ocorrem muitas diferenças no que diz respeito à aspereza da folha, entre diferentes espécies de plantas. As superficies podem ser relativamente macias (Beta vulgaris), enrugadas (Syringa vulgaris) ou com papilas abundantes. Espécies glaucas são caracterizadas por uma cobertura adicional de ceras 
epicuticulares cristalinas (Brassicas spp.; Pisum sativum.) enquanto que determinadas espécies possuem tricomas glandulares, que são células epidérmicas modificadas, como aspecto dominante de suas superficies (Glycine max; Abutilon theophrasti). Muitas vezes mais do que um tipo de aspereza é encontrada na superficie da cutícula e diferenças marcantes podem ocorrer na espécie, como entre a superficie abaxial e adaxial na mesma folha. Superficies cerosas e com abundante número de tricomas são geralmente os alvos mais dificeis de serem molhados por serem hidro repelentes (Holloway, 1993).

Uma área pequena de contato entre a gotícula da calda pulverizada e a superficie da cutícula, limita o potencial para a difusão entre a calda e a cutícula logo, todos os aspectos das superficies foliares (topografia das células, o grau e tipo de desenvolvimento da cera epicuticular, tricomas e glândulas) influenciam a deposição do herbicida nas superficies foliares. Como é visto, há uma grande diversidade na morfologia epidérmica entre as várias espécies de folhas e é de grande importância que as conheça para que se compreenda o comportamento do herbicida a ser absorvido (Hess \& Falk, 1990).

\subsection{Interação entre o herbicida e a superfície foliar}

Como todas as partes aéreas das plantas são cobertas pela cutícula, Devine (1990) ressalta que a natureza fisica e química das superficies foliares é de fundamental importância para a determinação na eficácia do herbicida.

Em virtude da sua estrutura e composição química, a cutícula tem certas propriedades importantes que interessa conhecer, para o esclarecimento dos mecanismos do movimento dos produtos na cutícula. As propriedades mais importantes da cutícula são a hidrorrepelência, a hidrofilia e a polaridade. Para 
uma superficie plana artificial, não molhável, o ângulo de contato de uma gota de água não passa de $105^{\circ}$. As folhas no entanto, apresentam ângulos de contato aparentes bem maiores, em virtude das irregularidades das suas superficies, causadas pelas microprojeções de ceras e outras, tais como dobras e franjas da cutícula e pelos epidérmicos (Camargo \& Silva, 1975).

A cutícula, não é totalmente hidrorrepelente. Há folhas que são molháveis, outras pouco molháveis e outras não molháveis pela água. A hidrorrepelência da cutícula depende da densidade e da forma das microprojeções de cera, da espessura da camada cerífera superficial e da composição química das ceras, que podem aumentar a hidrorrepelência, não só por aumentar o ângulo de contato das gotículas de água com a superfície, mas também por manter junto à superficie uma fina camada de ar, que impede o contato direto das gotículas com a superficie cuticular (Carvalho ${ }^{1}, 1994$; Camargo \& Silva, 1975).

Em trabalho de comparação entre diferentes espécies, Ruiter et al. (1990) citando Holloway ${ }^{2}$ (1970), concluem que a natureza da superficie cuticular, parece ser o fator mais determinante na retenção do herbicida. A presença de uma camada de ar na interface entre a gota, a superficie cristalina e o caráter hidrofóbico das ceras epicuticulares são considerados como fatores que lideram no aumento do ângulo de contato. Além disso, a cera epicuticular, permitindo que o ar permaneça entre a gota pulverizada e a superficie da planta, aumenta a chance dessa gota de ser arrastada da folha. A retenção do herbicida varia entre as espécies, com as formulações do herbicida e com o surfactante utilizado na calda pulverizada (Nalewaya et al., 1992).

\footnotetext{
${ }^{1}$ CARVALHO, J.C. Efeitos de adjuvantes na eficácia dos herbicidas. Manuscrito, 20p. 1994.

${ }^{2}$ HOLLOWAY, P.J. Surface factors affecting the wetting of leaves. Pesticide Science. v.1, p.156-163. 1970
} 
A retenção das gotas pulverizadas da calda herbicídica depositada na superficie foliar, é essencial para a eficácia dos herbicidas aplicados em pós emergência. As características da superficie foliar influenciam o padrão da distribuição dos herbicidas. Conforme citam Ruiter et al. (1990) e Nalewaya et al. (1992), a retenção das gotas pulverizadas é melhor em plantas que possuem folhas com superficie cuticular plana do que as que possuem folhas com superficie contendo ceras epicuticulares cristalinas.

Da mesma forma, Hess \& Falk (1990) demostram como as características da superficie foliar causam diferentes modelos de distribuição da calda sobre a mesma. Em superficies foliares com pouco desenvolvimento das ceras epicuticulares; como a folha da beterraba açucareira, as gotas do herbicida expandem-se formando grandes áreas e produzem depósitos nas depressões das paredes anticlinais. Quando o mesmo herbicida é aplicado em folhas com grande desenvolvimento das ceras epicuticulares como a espécie Cynodon dactylon, os depósitos são menores e uma pequena área é coberta pelo herbicida, dessa forma reduzindo a porcentagem de cobertura das células onde a absorção pode ocorrer.

A absorção foliar de herbicidas é um processo complexo, que envolve a passagem de moléculas dos herbicidas da superficie externa das folhas das plantas, através da cutícula e para dentro de tecidos subjacentes. Devine $\&$ Born (1991) citam que a absorção dos herbicidas pode ser vista como um processo com três etapas nas quais primeiramente o herbicida se divide dentro da cutícula, depois então se difunde através da mesma e então sofre partições para fora da cutícula, através do apoplasto ou em áreas das paredes das células epidérmicas.

A passagem das moléculas para dentro das folhas ocorre em função da natureza fisica e química da cutícula, das propriedades dos herbicidas, dos ingredientes que acompanham a formulação e do ambiente que a folha tenha se desenvolvido. Entretanto, as experiências têm mostrado que há poucas regras que 
governam a absorção de herbicidas e que cada combinação herbicida/espécie de planta/formulação/ambiente tem características próprias e únicas (Devine et al., 1993).

A penetração diretamente através da cutícula é considerada a principal via de absorção de herbicidas pelas folhas. Apesar disso, existem trabalhos discordantes, mas a totalidade dos autores conclui que a absorção estomática possui limitada importância prática (Velini \& Trindade, 1992). Hess (1996a e 1996b) cita que a penetração via estômatos de gotas pulverizadas via solução aquosa é um processo complexo e não ocorre em aplicações de herbicidas no campo, sem o uso de surfactantes. A penetração estomatal não é possível a menos que a tensão superficial da solução pulverizada seja significativamente reduzida pelo uso de surfactantes na formulação do herbicida ou na mistura de tanque e essa tensão da calda deve ser menor do que a tensão superficial crítica da penetração estomatal. Muitos surfactantes não são hábeis a reduzir a tensão superficial adequadamente para permitir a penetração estomatal, entretanto os surfactantes organosiliconados reduzem a tensão superficial a um ponto tal que essa penetração ocorre. Muitos estudos mostram que os surfactantes organosiliconados também podem influenciar a absorção através da cutícula depois que a penetração estomatal ocorre e mostram que a cutícula é mais delgada em alguns locais na superficie da folha como em volta das células guarda.

Estudos também têm sido feitos para avaliar a absorção, levando em consideração a presença de tricomas. Ricotta \& Masiunas (1992) avaliaram catorze genótipos de tomate e obtiveram uma correlação inversa entre a atividade de acifluorfen em determinado genótipo e a freqüência de tricomas (quanto mais tricomas, menos atividade). No mesmo estudo também foi detectado uma direta correlação entre freqüência de estômatos e sensibilidade ao acifluorfen. 
A cutícula pela sua constituição química, de ceras, pectina e celulose, oferece rotas de entrada para vários grupos da substâncias seja em estado iônico, seja em estado molecular. Logo, pode-se considerar que a cutícula apresenta duas rotas de entrada - a aquosa e a lipoidal. A rota aquosa é o caminho das substâncias hidrossolúveis, ionizadas ou não, que entram na cutícula através da água. A rota lipoidal é onde atravessam as substâncias oleosas, atravessam a cutícula facilmente pois, são solúveis nas ceras, e muitas delas, na cutina.

Tem havido algumas especulações na literatura da presença de canais hidrofilicos e lipofilicos através da cutina, e tem sido sugerido que os herbicidas se movem preferencialmente através desses canais, dependendo de suas propriedades físico-químicas (Devine, 1993). Entretanto, Price (1982) cita que nenhuma dessas rotas é exclusiva e que o movimento de herbicidas é um processo de difusão simples devido à falta de tecidos celulares vivos na cutícula.

O significado desses canais na absorção do herbicida ainda não é determinado. Apesar disso, é sabido que, dependendo da quantidade relativa de lipídeos solúveis cuticulares e cutina, há gradientes na polaridade no interior da membrana cuticular. De acordo com Hess (1985), a membrana cuticular pode ser melhor descrita como uma "matriz esponjosa" composta por regiões descontínuas polares e não polares.

As propriedades lipofilicas/hidrofilicas dos herbicidas são importantes no entendimento de sua absorção através da cutícula das plantas. Essas propriedades são mensuradas por determinação de seus coeficientes de partição octanol/água $\left(\mathrm{K}_{\mathrm{ow}}\right)$, que é uma medida de hidrofobicidade de compostos químicos. Herbicidas lipofilicos têm altos valores de $\mathrm{K}_{\mathrm{ow}} \mathrm{e}$ os hidrofilicos têm baixos valores. Esses valores são muitas vezes expressos como $\log \mathrm{K}_{\mathrm{ow}}$ e muitos herbicidas estão entre os em limites de -5 (hidrofilicos) e +5 (lipofilicos). Herbicidas lipofilicos, solúveis em óleo e formulações emulsionáveis, são hábeis a penetrar através da 
barreira cuticular por simples difusão através dos componentes lipofilicos dominantes. A velocidade do movimento do herbicida através da cutícula é dependente das propriedades do seu veículo (solubilidade ou permeabilidade no interior da cutícula) e sua força de penetração (gradiente de concentração). A difusão de herbicidas lipofilicos através da camada epicuticular, é feita fundamentalmente através daquelas ceras que estão em estado amorfo. Formulações de herbicidas solúveis em água (sais) também são hábeis a penetrar através da superficie cuticular por simples difusão. Entretanto, devido à sua baixa permeabilidade pela cutícula, sua velocidade de movimento é significativamente menor do que a dos herbicidas lipofilicos. Esta reduzida permeabilidade, muitas vezes resulta em uma absorção total menor de herbicida pela planta (Hess, 1996a).

Os mecanismos que promovem a absorção foliar de herbicidas através dos surfactantes (como os ativadores) ainda são pouco conhecidos. Sabe-se que eles podem afetar a cobertura da solução, a retenção da gota pulverizada ou o estado fisico da mesma na superficie cuticular, ou mudando a estrutura e composição da cutícula, desta forma incrementando a difusão. Em adição, eles podem funcionar alterando as relações de solubilidade no interior da cutícula, desde que eles penetrem rapidamente e em quantidades substanciais possivelmente habilitando a penetração conjunta do surfactante e do ingrediente ativo. Enquanto os mecanismos envolvidos ao nível cuticular não são claros, a difusão através da parede externa da cutícula aparece como sendo a primeira barreira à penetração foliar de solutos. Quando resistências à difusão ocorrem, sob determinadas circunstâncias, a presença de adjuvantes pode particularmente facilitar a penetração cuticular (Kirkwood, 1993). 
Stock \& Holloway ${ }^{3}(1993)$, citado por Salas Pino (1996), relatam que vários fatores chaves tem sido identificados no processo de ativação da absorção dos herbicidas, os quais podem acontecer nas gotas, no depósito formado na superficie das folhas, na cutícula antes ou durante a penetração, sob os tecidos do local de aplicação ou na membrana celular. Os detalhes precisos dos seus mecanismos de ação, no entanto, ainda não foram bem esclarecidos.

\subsection{Influência de adjuvantes na superfície foliar}

\subsubsection{Características e tipos de adjuvantes}

Muitas confusões são feitas sobre adjuvantes devido em parte, a falta de definições precisas. Os adjuvantes têm muitas funções e muitos termos baseados nessas funções. Amplos grupos de adjuvantes incrementam a absorção, auxiliam na deposição, prolongam o resíduo, ajudam na compatibilidade, superam 0 antagonismo, reduzem a deriva ou melhoram outras características da aplicação. A Weed Science Society of America (WSSA) define adjuvantes como sendo qualquer substância na formulação do herbicida ou adicionado ao tanque de pulverização que modifique suas atividades biológicas ou as características da aplicação. Entretanto existem pelo menos seis outras definições publicadas (Green, 1995).

Hess (1996b) define adjuvante como qualquer material adicionado à solução de pulverização de um herbicida que aumente ou modifique a performance da solução.

\footnotetext{
${ }^{3}$ STOCK, D. ; HOLLOWAY, P.J. Possible mechanism for surfactant-induced foliar uptake of agrochemicals. Pesticide Science, v.38, p.165-77, 1993.
} 
Van Valkenburg (1982) classifica os adjuvantes em duas categorias gerais: modificadores da solução e ativadores, e Hess (1996b) relata que os modificadores da solução são aqueles adjuvantes que mudam as características umidificantes, adesionantes e espalhantes da solução enquanto que os ativadores, fundamentalmente, influenciam a absorção do herbicida através de uma interação direta com a cutícula vegetal.

Os surfactantes, que são os tipos mais comuns de adjuvantes, englobamse muitas vezes nos dois tipos de classificação funcionando ora como modificadores da solução, ora como ativadores. Matuo et al. (1989) comentam que os surfactantes são substâncias, que adicionadas em pequenas quantidades, à soluções, suspensões ou emulsões, diminuem as tensões interfaciais e estabilizam as fases dispersas desses sistemas. Visam também proporcionar uma deposição e retenção mais efetiva da pulverização no alvo do tratamento.

Toda molécula de surfactante possui o aspecto comum de ser composta por um grupo apolar de longa cadeia hidrocarbonada lipofilica e um grupo polar hidrofilico. $\mathrm{O}$ grupo polar é que pode ser iônico (catiônico ou aniônico) ou não iônico.

$\mathrm{Na}$ terminologia de agente ativador de superficies, um tipo aniônico de molécula obviamente ioniza na água, e a porção ativa da molécula (que contém os segmentos hidrofilicos e lipofilicos) é um ânion. Os mais comuns são os fosfatos, carboxilatos e sulfatados como por exemplo o lauril-sulfato de sódio. No caso dos catiônicos, a porção ativa é um cátion e os tipos mais comuns nos produtos comerciais produzem a carga positiva, geralmente derivada de um átomo de $\mathrm{N}$ contido numa amina ou composto de amônio quaternário. Raramente são usados em formulações ou em caldas de produtos fitossanitários, pois a tendência de serem reativos pode criar incompatibilidades. Muitos compostos catônicos são 
fitotóxicos sendo que alguns são usados como desfolhantes (Van Valkenburg, 1982; Kissmann, 1999).

Os mais usados em formulações de produtos fitossanitários são os surfactantes aniônicos e os não iônicos sendo que este último não ioniza e por isso não tende a alterar o equilibrio eletrolítico nas formulações e nas caldas. São relativamente inertes, apresentando boa compatibilidade com os diversos ingredientes ativos e demais componentes das formulações. Formam o grupo mais importante entre os tensoativos para produtos fitossanitários (Anderson, 1977; Kissmann, 1999).

A maioria dos surfactantes não iônicos possuem cadeias de oxietileno (ou óxido de etileno) ( $\left.-\mathrm{CH}_{2}-\mathrm{CH}_{2}-\mathrm{O}-\right)$ como grupo polar (hidrofilico). $\mathrm{O}$ número de unidades de óxido de etileno na porção polar do surfactante não-iônico é muitas vezes referido como "número de moles de óxido de etileno (EO)". Quanto mais unidades de óxidos de etileno (EO) mais polar é o surfactante. A polaridade de um surfactante pode ser modificada pelo constituinte do final da cadeia de oxietileno. Como os adjuvantes possuem propriedades tanto lipofilicas como hidrofilicas, podem interagir com superficies lipofilicas das plantas e herbicidas lipofilicos assim como com herbicidas hidrofilicos e com água. Em geral, herbicidas lipofilicos são melhorados por surfactantes que possuam um pequeno componente hidrofilico (baixos moles de EO) enquanto que os herbicidas hidrofilicos (solúveis em água), são melhorados por surfactantes com grande conteúdo de EO (grandes componentes hidrofilicos) (Hess, 1996b).

Kirkwood (1993) cita que em trabalho realizado com glifosate pulverizado sobre aveia ( $A$. sativa ) e feijão ( $V$. faba ) e surfactantes com variação do número de EO mostrou que os surfactantes com alto conteúdo de EO (15-20), foram mais eficazes na absorção do glyphosate enquanto que aqueles com mais baixo conteúdo de EO (5-10), reduziram ou não melhoraram a sua absorção. Correlações entre o 
conteúdo de EO e composições hidrofóbicas também ocorrem quando os surfactantes induzem a uma absorção de componentes mais lipofilicos.

A solubilidade dos surfactantes em água ou em solventes orgânicos, depende da predominância da sua parte hidrofilica (grupos polares) ou lipofilicas (cadeia hidrocarbonada) na molécula. Os surfactantes são muitas vezes determinados e nomeados por um valor do "Balanço Hidrofilico - Lipofilico" (BHL), que é uma avaliação de sua hidrossolubilidade e lipossolubilidade. Em um certo sistema, o BHL é dado por uma distância numérica de 0 a 20 . Os surfactantes lipofilicos são determinados por um BHL de 8 para baixo. Os surfactantes com número BHL de 9 a 11 são intermediários e aqueles com BHL acima de 11 são hidrofilicos .

Em baixas concentrações, os surfactantes são solúveis em água. Entretanto, conforme cita Hess (1996b), a concentração do surfactante é, comumente aumentada no uso para controle de plantas daninhas ocasionando uma agregação entre as moléculas do surfactante, chamada de micelas. As micelas podem emulsificar substâncias lipofilicas, incluindo herbicidas, óleos e talvez componentes cuticulares. A concentração de saturação da solução, em que inicia a formação das micelas é denominada Concentração Micelar Crítica (CMC). Nas micelas, as moléculas anfipáticas do surfactante se dispõem com as extremidades polares (denominadas cabeças) dirigidas para a água, e as cadeias hidrocarbonadas, apolares (denominadas caudas) entrelaçadas no interior, formando o núcleo lipofilico da micela.

Os três principais tipos de adjuvantes são os surfactantes (iônicos ou não), os óleos (minerais ou vegetais) e os fertilizantes.

Os óleos usados na agricultura são de dois tipos primários: óleos minerais refinados (à base de petróleo, como parte específicasda destilação do mesmo) e 
óleos de sementes (chamados de óleos vegetais). Óleos minerais não fitotóxicos usados como adjuvantes, usualmente têm uma alta proporção de óleos parafínicos (cadeias longas, retas ou ramificadas de hidrocarbonetos com comprimento de cadeia variando entre 18 a 30 carbonos). Os óleos vegetais são extraídos das plantas e o comprimento de sua cadeia de hidrocarbonetos tem um total de 16 a 18 carbonos. Existem também os óleos vegetais metilados, que são produtos de um processo de esterificação metílica que permitem a formulação de adjuvantes de performance muitas vezes superior à dos óleos vegetais simples ou minerais (Hess,1996b ; Kissmann, 1999). Segundo Durigan (1993), dentre as principais vantagens do uso do óleo na aplicação de defensivos agrícolas, pode-se destacar a diminuição da evaporação das gotas, a maior facilidade de penetração de calda pela cutícula, além de poder reduzir a hidrólise do defensivo na água do tanque e reduzir a fotodecomposição causada por certos comprimentos de onda do espectro luminoso.

Dentre os surfactantes, um grupo que tem sido muito estudado nos últimos anos é o grupo dos surfactantes siliconados. Esses surfactantes têm sido usados com diferentes agroquímicos para melhorar a molhabilidade $\mathrm{e}$ espalhamento da calda, incrementando a absorção de ingredientes ativos.

Os siliconados são uma classe de surfactante onde uma ordenação de grupos metil $\left(\mathrm{CH}_{3}\right)$, ligados a átomos de silicone constituem a parte hidrófoba da molécula. A hidrofobicidade da cadeia de silicone não está associada com a presença do silício, mas com a flexibilidade da cadeia de siloxane em expor seus grupos metil na interface entre o surfactante e o meio. Os grupos metil são mais hidrófobos do que os grupos metilene $\left(\mathrm{CH}_{2}\right)$ que constituem a parte mais importante dos surfactantes convencionais (Goddard, 1992; Hess, 1996b).

Apesar desse compacto corpo hidrófobo (trisiloxane) ser requerido pela sua habilidade extrema de diminuir a tensão superficial e melhorar a expansão da 
calda, o comprimento da cadeia hidrofilica e a extremidade do final dessa cadeia pode ser variada para formar uma série de surfactantes organosiliconados afins (Sun \& Foy, 1995).

Os efeitos dos surfactantes siliconados na absorção foliar de agroquímicos têm sido extensamente investigados e revistos (Stevens, 1993; Knoche, 1994). Os surfactantes organosiliconados aumentam a absorção foliar em muitas espécies e isto é fundamentalmente devido a sua habilidade de difusão da calda pulverizada e redução de tensões superficiais a baixos valores, desde modo capacitando soluções pulverizadas a infiltrar via estômatos (Gaskin, 1995).

\subsubsection{Efeitos de adjuvantes na superfície foliar}

Enquanto algumas propriedades físico-químicas do ingrediente ativo que favorecem a penetração do herbicida têm sido identificadas, pouco é conhecido sobre as propriedades físico-químicas dos surfactantes e como eles afetam as interações entre gota pulverizada e a superfície da planta. Variações no comprimento da cadeia de oxietileno de surfactantes não iônicos têm sido usadas para investigar a relação entre atividade e estrutura nos estudos dos surfactantes. Apesar dos efeitos dos conteúdos dos oxietilenos na absorção de alguns ingredientes ativos, diferindo em suas características fisico-químicas, estarem sendo reportados (Stevens \& Bucovac, 1987), pouca ênfase tem sido dada para as características da superficie foliar da planta em estudo (Price \& Anderson, 1985). Recentes estudos têm indicado que a melhora que o surfactante dá na absorção de determinado componente varia profundamente entre as espécies (Stevens \& Baker, 1987). 
Segundo Hess (1996b), um importante aspecto dos surfactantes usados como adjuvantes, é reduzir a tensão superficial da solução pulverizada para que se permita um contato mais íntimo entre a gota pulverizada e a superficie foliar. Muitos efeitos dos surfactantes ocorrem em concentrações bem acima da CMC, entretanto os mecanismos de ação dos surfactantes devem ser mais do que simplesmente reduzir a tensão superficial da solução pulverizada.

Os principais efeitos da adição de surfactantes às caldas, segundo Durigan (1993), são: a) espalhamento da solução na superficie cuticular, pelo rompimento da tensão superficial da água e redução no ângulo de contato; b) cobertura mais uniforme da superficie foliar, melhor contato e maior aderência da calda, possibilitando maior probabilidade de penetração dos solutos através da via própria (aquosa ou lipoidal); c) expulsão da camada de ar formada em função da pilosidade, na superficie da cutícula, promovendo total molhamento; d) durante a penetração dos íons ou moléculas, através da cutícula, o surfactante diminui as tensões interfaciais entre as regiões submicroscópicas polares e apolares (cutina - água, cutina - pectina, ceras - água, ceras - pectina, celulose cutina), evitando as retenções dos íons ou moléculas da calda nessas interfaces ; e) facilitam a penetração de íons para o simplasto através da plasmalema; f) promovem maior penetração pelos estômatos através da maior molhabilidade da cutícula.

Os surfactantes têm seu maior efeito na tensão superficial das gotas pulverizadas, na interface água/ar e no ângulo de contato da interface água/planta. Eles também influenciam o espectro das gotas pulverizadas, na deriva e na eficiência da transferência do produto para a superficie foliar, afetando sua adesão, espalhamento, molhabilidade, cobertura e escorrimento. Os surfactantes podem agir também como umectantes, mantendo o ingrediente ativo na fase líquida por um período mais longo ou talvez possuir propriedades solubilizantes, 
as quais facilitam a partição do ingrediente ativo da fase sólida para a fase líquida (Kirkwood et al., 1992).

Tem sido sugerido que em altas concentrações, os adjuvantes podem solubilizar as ceras da cutícula, promovendo a maior facilidade na penetração cuticular. Se for esse o caso, então a combinação de reduzir a tensão superficial, melhorar a retenção e solubilizar as ceras epicuticulares, pode aumentar a penetração cuticular e a absorção foliar. Há evidências de que determinados surfactantes tem a capacidade de introduzirem-se nos tecidos foliares e essa relação entre estrutura e fitotoxicidade tem sido investigada por vários autores (Kirkwood et al., 1992 ; Kirkwood, 1993).

Ruiter et al. (1990) citam que as espécies que tiveram dificuldade de serem molhadas, retiveram mais calda quando esta continha uma maior concentração do surfactante. Esse resultado indica que uma maior concentração do surfactante é requerida para que se possa ultrapassar a barreira formada por ceras epicuticulares cristalinas.

Dayan et al. (1996) demonstram que as folhas da espécie Senna obtusifolia não retiveram as gotas da calda contendo herbicida sulfentrazone quando não foi usado nenhum surfactante. Essa ausência de surfactante apresentou uma relação inversa entre a quantidade de cera cuticular e a quantidade de herbicida absorvido. Plantas com mais ceras cuticulares como a Cassia occidentalis e Senna obtusifolia absorveram relativamente menos sulfentrazone do que espécies com quantidades menores de ceras. 


\subsection{Herbicidas mimetizadores de auxina}

Uma vez que um herbicida penetra na planta e se transloca para o local em que pode atuar especificamente, ocorre o que se denomina mecanismo de ação. O mecanismo de ação de um herbicida não é, sempre, limitado a uma reação específica ou à inibição de um único passo metabólico. $\mathrm{Na}$ maioria das vezes um composto, ou compostos de um determinado grupo químico, pode atuar em diferentes processos, dependendo da dose aplicada, da espécie que recebeu a aplicação e das condições de clima. Costuma-se atribuir a cada herbicida um mecanismo único ou específico de ação devendo-se na realidade, considerar este como o principal ou o mais destacado (Deuber, 1992). Uma outra definição atribuída a Vidal (1997), explica que o mecanismo de ação de um herbicida refere-se ao evento molecular que é afetado ou inibido pelo acoplamento da molécula xenobiótica à macromolécula biologicamente relevante ; primeira lesão, bioquímica ou biofísica no interior celular, causada na planta pelo herbicida, e que resulta na ação final de injúria ou morte.

O grupo de herbicidas reguladores de crescimento inclui todos os herbicidas com ação hormonal, e por isso influenciam o balanço hormonal existente na planta. $O$ exato mecanismo de ação ainda não está bem definido, porém acredita-se que aumentem a atividade da enzima RNA-polimerase, provocando acúmulo de RNA e aumento no teor de proteínas. Com mais RNA, é estimulada a síntese de hormônios como auxinas e giberelinas, os quais promoverão divisão e alongamento celular acelerado e desordenado nas partes novas da planta, ativando seu metabolismo e levando-a ao esgotamento. $O$ crescimento celular estimulado causa epinastia. Nas raízes, a atividade da enzima carboximetilcelulase é aumentada, destruindo o sistema radicular das plantas sensíveis. 
As auxinas são hormônios das plantas. Elas regulam o crescimento da célula vegetal e sua diferenciação em cooperação com outros hormônios vegetais. O mecanismo molecular da ação das auxinas, ainda não é conhecido em detalhes mas, sabe-se que uma importante faceta da ação das auxinas é a sensibilidade dos diferentes tecidos. Essas diferenças têm sido encontradas entre diferentes tecidos como sementes, raízes, meristemas ativos ou calos e entre tecidos de diferentes estágios fisiológicos de crescimento. Em uma planta em crescimento, em qualquer tempo específico, um tipo de tecido pode responder à auxina, enquanto outros não. O tipo de resposta pode ser positiva ou negativa, inibitória ou estimulante dependendo da concentração da auxina ou a presença simultânea de outros hormônios vegetais. $\mathrm{O}$ efeito mais rápido e mais óbvio induzido pela auxina e pelos herbicidas auxínicos é o crescimento pela elongação celular (Devine et al., 1993).

É necessário uma consideração rápida sobre a visão corrente no modo de ação das auxinas para que se possa identificar as bases da fitotoxicidade dos herbicidas auxínicos ou hormonais. Entretanto, apesar dos 40 anos de pesquisa extensiva somados ao grande uso desses herbicidas, não há uma visão universal a respeito dos receptores das auxinas e a respeito dos eventos seguintes a essa ligação. Dois tipos de respostas induzidas pela auxina são reconhecidas após essa ligação. Uma resposta rápida entre dez e vinte minutos e uma resposta lenta, entre uma e duas horas depois. A resposta rápida conduz a uma ativação da ATPase no plasmalema, a qual induz um efluxo de prótons, resultante na acidificação da parede celular e sua perda. Este é o primeiro efeito fisiológico detectável do sítio de recepção e tem sido extensivamente investigado com respeito à auxina e o herbicida. Esta resposta sozinha, não consegue explicar a atividade bioquímica das auxinas ou a razão para a fitotoxicidade dos herbicidas hormonais. Uma segunda resposta ocorre de 45 minutos a 2 horas depois da vinculação do receptor 
e envolve transcrição e tradução, o que quer dizer, síntese de RNA e síntese de proteínas (Kirkwood, 1991).

Incrementos na síntese de RNA têm sido reportados no prazo de poucas horas do tratamento dos herbicidas hormonais. Inicialmente pensava-se que a resposta rápida era resultado do efluxo de prótons induzido pela ligação das auxinas diretamente pela ATPase do plasmalema; entretanto, parece que a ATPase não é um receptor auxínico. Na verdade, parece ser provável que ambas as respostas são induzidas por um ainda desconhecido segundo mensageiro, o qual dispara respostas das auxinas. A figura 1 representa um esquema fechando as visões correntes dos eventos que se seguem à ligação entre a auxina e o receptor.

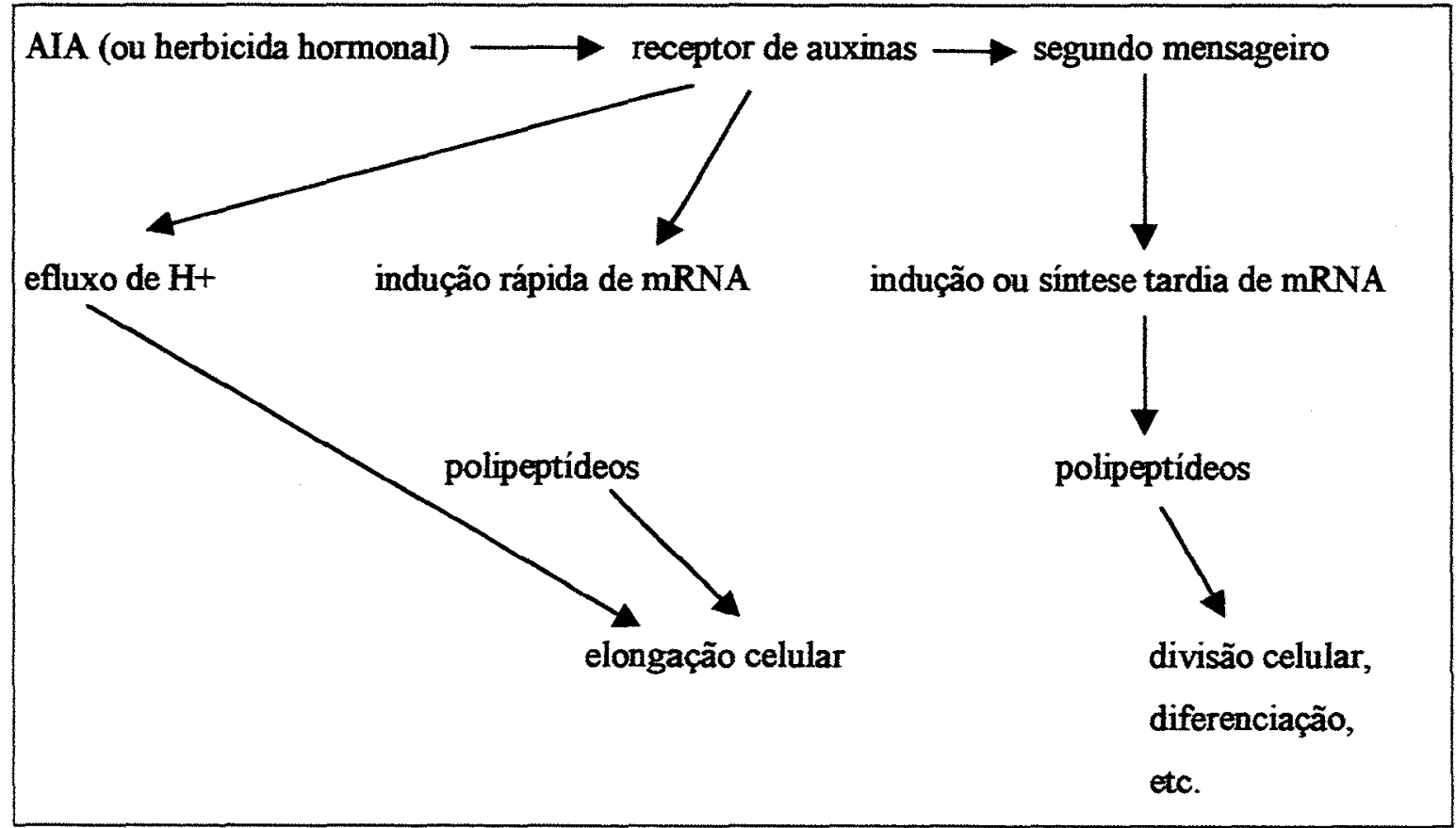

Figura 1 - Esquema de duas respostas resultantes de ligação entre a auxina ou herbicida hormonal ao receptor de auxinas.

Fonte: Adaptado de Kirkwood (1991). 
É proposto que a rápida resposta fisiológica do efluxo de prótons é mediada por uma indução rápida de RNA mensageiros. A segunda resposta da regulação indireta das auxinas inchui indução ou síntese de mRNAs codificando para celulases, hidrolases e polipeptídeos necessários para a divisão celular, diferenciação e indução meristemáticas .

A inibição do crescimento das plantas, sob a ação de compostos químicos, pode ser direta ou indireta, ou ambas, simultaneamente. A inibição direta é resultado da ação do herbicida sobre a distensão celular. Essa distensão ocorre em função do aumento da plasticidade da parede celular. A inibição indireta resulta da redução da divisão celular, da interferência na síntese de proteínas, enzimas, ácidos nucleicos e hormônios, como o AIA, alterações morfológicas e bloqueio do fluxo da seiva.

Estudos anatômicos e morfológicos em plantas tratadas com herbicidas auxínicos revelam uma série de sintomas desenvolvidos incluindo danos severos ao nível de cloroplasto liderados por clorose de folhas, alteração da função do estômato, proliferação do tecido do caule e desintegração do tecido da raiz e crescimento apical anormal (Kirkwood, 1991).

Fedke (1982) sumariza que a seqüência de sintomas pode ser associada com três fases da ação do herbicida: estimulação de processos metabólicos; distribuição de aberrações morfológicas; e, colapso de tecidos e declínio da planta.

Uma proposta para a ação fitotóxica dos herbicidas auxínicos, é que ocorra um metabolismo anormal do ácido nucleico induzido por um desbalanço hormonal em tecidos tratados.

Os compostos dos grupos auxínicos, também chamados de hormonais, com o 2,4-D, 2,4,5-T, MCPA, e os benzóicos, como o dicamba, atuam sobre o 
crescimento, desorganizando-o em geral. Nas folhas, as nervuras, portadoras de vasos, crescem rapidamente sob o estímulo de um herbicida auxínico, ao passo que o tecido internerval não acompanha o mesmo ritmo de crescimento, por não receber o mesmo estímulo. Na planta como um todo, pode haver encurvamento de caule, ramos e pecíolos, pelo fato de a distribuição do herbicida não se dar uniformemente (Deuber, 1992).

Os principais sintomas visíveis de fitotoxicidade são:

- epinastia das folhas, retorcimento de pecíolos, pedúnculos e caules;

- paralização do crescimento e engrossamento das gemas;

- formação de tumores ao longo do caule da planta , obstrução do floema (as divisões celulares no floema impedem o fluxo, provocando acúmulo de reservas e intumescimento num ponto do caule), redução na translocação de fotoassimilados;

- engrossamento das raízes principais, morte das raízes secundárias e formação de raízes adventícias;

- redução na absorção de água e sais minerais, causada pela morte das raízes secundárias e dos pêlos absorventes;

- mudança no geotropismo;

- inibição da fotossíntese, da respiração e, por conseqüência, morte da planta. 


\section{MATERIAL E MÉTODOS}

Os dois experimentos foram conduzidos nas instalações da Escola Superior de Agricultura "Luiz de Queiroz"- Universidade de São Paulo, Piracicaba, SP, Brasil.

\subsection{Descrição das espécies de guanxuma (Sida spp)}

Foram utilizadas nos dois experimentos, três espécies da planta daninha Sida spp., que serão descritas a seguir, segundo Kissmann \& Groth (1995):

\section{a) Sida rhombifolia}

Planta da família Malvaceae nativa do Continente Americano, ocorrendo intensamente na América do Sul. No Brasil é a espécie mais comum na Região Sul, ocorrendo todavia em todas as regiões. Em importância econômica negativa, mostra-se como uma infestante agressiva em culturas diversas, pastagens e áreas desocupadas. Dificulta a colheita mecânica em culturas anuais, pelos caules muito resistentes. Quanto a sua biologia, é uma planta perene reproduzida por semente, sendo que em culturas anuais, com preparo de solo, as plantas de guanxuma são destruídas e a reinfestação ocorre por sementes, o que sugere que a planta seja anual, ocorrendo guanxumas perenes só nas curvas de nível e margens de lavouras, por escaparem ao trabalho mecânico. Em sua morfologia, são plantas 
eretas, bastante ramificadas, atingindo normalmente até $60 \mathrm{~cm}$ de altura, mas em condições ideais pode se tornar semi - arbustiva e atingir até $1,50 \mathrm{~m}$ de altura. Tolera solos fracos e ácidos, mas seu desenvolvimento é limitado. Solos de textura mediana, são ideais. Fotossíntese pelo ciclo C3. Folhas com formato rômbico.

\section{b) Sida cordifolia}

Planta da familia Malvaceae nativa da América Tropical, hoje encontrada em diversas regiões de clima tropical e subtropical no mundo. No Brasil ocorre em todos os estados, com maiores concentrações na Amazônia, Minas Gerais, São Paulo e Norte do Paraná. Em termos de sua importância econômica negativa, é infestante em pastagens e culturas diversas, sendo bastante agressiva em solos férteis.. Quanto a sua biologia, é uma planta perene reproduzida por sementes, de clima quente, sendo que nas regiões Centro e Sudeste floresce no fim do verão. Aceita solos arenosos mas, fica com seu porte diminuído. Em solos mais argilosos, sendo férteis, atinge um porte de até 2 metros. Fotossíntese pelo ciclo C3. Folhas largas, cordiformes com nervuras bem marcadas na face ventral e proeminentes na dorsal e veludosas.

c) Sida glaziovii

Planta nativa do Brasil, ocorrendo com intensidade nas regiões Sudeste e Centro-Oeste, com presença também em outras regiões. Sua importância econômica negativa está em ser infestante de culturas anuais e perenes, com da soja, algodão, café e outras; infestante em pastagens e áreas não cultivadas. Quanto a sua biologia, é uma planta reproduzida por sementes, ocorre em todos os tipos de solo, exceto em áreas muito úmidas. Resistente a períodos de seca. As folhas especialmente quando novas, apresentam um movimento no limbo, de forma a posicioná-la junto aos ramos em condições de iluminação reduzida, como 
em dias nublados e ao entardecer. Este é um aspecto interessante, ao fazer a aplicação do herbicida, pois a superficie de exposição é reduzida. É uma planta ereta, com altura de $30-60 \mathrm{~cm}$. Geralmente ocorrem muitos caules juntos, às vezes formando touceiras consideráveis. Geralmente o limbo foliar é ovalado e grosso, muito aveludado pela intensa pilosidade.

\subsection{Características morfológicas da cutícula foliar de três espécies de guanxuma}

As plantas das espécies de guanxuma cresceram sob condições de casa de vegetação, até que apresentassem de 15 a $20 \mathrm{~cm}$ de altura, em estádio foliar de crescimento, relativo à oito a dez folhas, que é o estádio quando o controle químico é realizado.

\subsubsection{Determinação da espessura da membrana cuticular}

Inicialmente a membrana cuticular das espécies foi observada sob microscópio de luz, o qual continha uma ocular micrométrica para que se pudesse conhecer e ser realizada a medição da espessura da cutícula sem uso de tratamento algum. Os cortes nas folhas foram feitos à mão livre. 


\subsubsection{Preparação do material}

Foram coletadas três folhas por vaso, por espécie, selecionada no terço médio da planta quando as mesmas apresentavam estádio foliar de crescimento relativo à oito a dez folhas. Foi utilizada a técnica a mão livre $\mathrm{n}^{\circ} 2 \mathrm{Semi}$ permanente do Laboratório de Anatomia Vegetal do Departamento de Ciências Biológicas da ESALQ, que implica em realizar cortes com material fresco, clarificar com hipoclorito de sódio $20 \%$ (cândida) e lavar em água destilada várias vezes até não sentir mais o cheiro de cândida.

Foi usado para coloração do material um corante específico para a cuticula, o Sudan IV. Para montagem da lâmina, colocou-se com um bastão de vidro, uma pequena quantidade de gelatina glicerinada na lâmina; colocou-se os cortes do material na lâmina e em seguida a lamínula. Após esse procedimento o material já pôde ser observado em microscópio de luz.

\subsubsection{Leitura em microscópio de luz}

Após a preparação do material, a amostra foi levada ao microscópio de luz para que se pudesse determinar a espessura da cutícula em um aumento de $\mathbf{4 0}$ vezes. A aferição da escala da ocular micrométrica foi realizada com o auxilio de uma régua micrométrica no mesmo aumento da observação da cutícula. 


\subsubsection{Caracterização da superfície foliar com o uso da Microscopia Eletrônica de Varredura (MEV)}

Após o conhecimento da espessura cuticular, as plantas foram caracterizadas em microscópio de varredura para que fossem conhecidas as estruturas de sua superficie foliar e possíveis características da guanxuma, que possam de alguma maneira influenciar no seu controle, como, tricomas, estruturas cerosas e estômatos.

\subsubsection{Local}

A pesquisa foi realizada no Núcleo de Apoio à Pesquisa em Microscopia Eletrônica aplicada à pesquisa Agropecuária (NAP/MEPA), situado na Escola Superior de Agricultura Luiz de Queiroz, USP.

\subsubsection{Preparação do material: amostras biológicas}

Os protocolos para preparo de amostras biológicas podem variar dependendo da natureza do espécimen a ser fixado. As variações podem ocorrer nas condições de fixação como por exemplo, componentes, concentração e tempo necessário. Foram feitos cortes à mão nas folhas com tamanho aproximado de $0,5 \times 0,5 \mathrm{~cm}$ para estudo tanto da superficie abaxial como da adaxial. 
Em todo o experimento foi usado o protocolo padrão do NAP/MEPA (Kitajima \& Leite ${ }^{4}$, 1998):

Para fixação do material foi usado o fixador Karnovsky modificado glutaraldeído $2,5 \%$, formaldeído $2,5 \%$ em tampão cacodilato de Sódio $0,05 \mathrm{M}$, $\mathrm{pH} 7,2$. Foi fixado em temperatura ambiente por 1 hora e o volume do fixador era em torno de 10 vezes o volume da amostra em tubos Eppendorff de 1,5 ml. Em seguida, o material foi lavado em solução tampão cacodilato $0,05 \mathrm{M}$, com três passagens de cerca de 10 minutos cada. Houve então a fixação em tetróxido de ósmio $\left(\mathrm{OsO}_{4}\right) \quad 1 \%$ em tampão cacodilato $0,05 \mathrm{M}$ por mais uma hora. Após a fixação, o material foi lavado em água destilada para seguir então à sua desidratação.

Após a lavagem em água destilada, o material foi passado em soluções de concentrações crescentes de acetona $(30 \%, 50 \%, 70 \%, 90 \%$ e $100 \%)$, permanecendo cerca de 10 minutos em cada uma e na solução de $100 \%$ foi passada 3 vezes por cerca de 10 minutos para que fosse desidratado.

Para que se possa contornar o problema da tensão superficial da acetona que causa, em amostras frágeis como a folha, a destruição de detalhes superficiais ou até o colapso do espécimen criando inúmeros artefatos, utiliza-se a secagem ao ponto crítico através de $\mathrm{CO}_{2}$ líquido.

Para se proceder a secagem ao ponto crítico, a mostra deve estar ainda imersa ou úmida em acetona e então deve ser colocada em uma câmara hermeticamente fechada e dotada de uma janela de observação, que deve estar resfriada por volta de 5- $6^{\circ} \mathrm{C}$. Esta câmara dotada de um manômetro, tem conexão regulada por uma válvula a um tanque de $\mathrm{CO}_{2}$, e outra com o meio exterior também controlada por válvula. Assim que a amostra é colocada na câmara, esta

\footnotetext{
${ }^{4}$ KITAJMA, E.W. \& LEITE, B. Curso introdutório de microscopia eletrônica de varredura. Apostila. 37p. 1998
} 
é fechada e permite-se a entrada de $\mathrm{CO}_{2}$ que se liqüefaz ficando a amostra nele mergulhado. Como existe um pouco de acetona na amostra o que impediria atingir o ponto crítico, esta acetona deve ser eliminada, o que é feito através de "enxágües". Parte do $\mathrm{CO}_{2}$ é removido, o suficiente para manter a amostra ainda mergulhada no líquido, pela válvula de saída, e a seguir enche-se de novo o reservatório com $\mathrm{CO}_{2}$ líquido. Esta operação é repetida 5 a 6 vezes até se assegurar que não há mais resíduos de acetona. Enche-se novamente a câmara, quase que totalmente, com $\mathrm{CO}_{2}$ e a seguir aquece-se a câmara fazendo-se a leitura no manômetro. Quando se atinge cerca de $30^{\circ} \mathrm{C}$ ocorre o ponto crítico. Espera-se a temperatura atingir cerca de $40 \mathrm{o} \mathrm{C}$, quando então elimina-se o gás lentamente, por cerca de 20-30 minutos, e a amostra estará seca, sem ter sofrido problemas de tensão superficial. $O$ aparelho de secagem ao ponto crítico usado no experimento foi modelo CPD 050 de Balzers. A amostra seca ao ponto crítico deve ser imediatamente montada e coberta com ouro, para evitar sua reidratação.

Quando o espécimen em estudo, embora rígido não seja metálico, for examinado diretamente, gerará imagens com problemas. Para evitar o efeito em que porções da superficie se tornam intensamente brilhantes, a superficie em estudo deve ser coberta com uma fina camada de metal. Isto pode ser obtido evaporando o metal (em geral ouro) à vácuo em um metalizador, estando a amostra em uma mesa rotativa para que o metal cubra todos os detalhes da superficie uniformemente. Uma maneira eficiente de proceder essa deposição metálica é um sistema conhecido com "sputtering". O aparelho usado no experimento foi o metalizador MED 010 da Balzers e foi feita uma deposição de ouro durante 150 segundos. 


\subsubsection{Observação em Microscópio Eletrônico}

Após a evaporação com metal as amostras das folhas foram observadas em microscópio de varredura Zeiss, modelo DSM 940A, operando entre 5 a 15 $\mathrm{kV}$.

\subsection{Controle químico das espécies de guanxuma (Sida spp)}

\subsubsection{Teste preliminar de germinação}

As sementes das plantas daninhas Sida spp. foram adquiridas junto a empresa Shokusho do Brasil e passaram pelos seguintes procedimentos para implantação do experimento:

No laboratório de sementes da ESALQ, foi conduzido teste preliminar com o objetivo de verificar as condições de germinação das sementes das espécies de guanxuma, com quatro repetições por espécie, com 50 sementes por repetição sob temperatura de $20^{\circ}$ e $30^{\circ} \mathrm{C}$ (padrão de germinação), sobre duas folhas de papel tipo filtro umedecidos com $13 \mathrm{~mL}$ de água destilada diariamente. A contagem das plântulas foi realizada até 28 dias, quando foram calculadas as porcentagens de germinação.

Após 28 dias de contagem, a porcentagem de germinação das três espécies não se mostrou favorável em nenhuma repetição (menos de 10\%). Foram realizados alguns testes para quebra de dormência para que se conseguisse germinações uniformes em casa de vegetação. Baseado em trabalho de Martins et al. (1997), três tipos de tratamentos foram utilizados: $\mathrm{H}_{2} \mathrm{SO}_{4}$ por 3 minutos (semente imersa em ácido sulfúrico por três minutos, lavado em água corrente e 
deixado secar à sombra) ; $\mathrm{H}_{2} \mathrm{O}$ por 2 horas (semente imersa em água à temperatura ambiente por duas horas e deixado secar à sombra) e escarificação mecânica (semente escarificada por processador elétrico com lixa fina em seu interior por 3 segundos). A contagem de germinação foi feita semanalmente até os 28 dias.

Após realizados testes para quebra de dormência, o tratamento que obteve melhor resultado foi o de escarificação mecânica por 3 segundos que promoveu lesões (arranhões, trincas e quebras) no tegumento das três espécies da familia Malvaceae, permitindo a embebição das sementes e o início do processo de germinação. Em casa de vegetação, na implementação do experimento, a germinação dessas sementes escarificadas foi de $100 \%$.

\subsubsection{Local do experimento}

O experimento foi conduzido em casa-de-vegetação do Departamento de Produção Vegetal. A temperatura média durante a condução do experimento foi mantida em $30^{\circ} \mathrm{C} \pm 5$ e as plantas foram irrigadas diariamente, duas vezes ao dia. O mesmo ensaio foi realizado para as três espécies analisadas.

\subsubsection{Semeadura}

Foram semeadas cinco sementes por vaso, em vasos de $1 \mathrm{~kg}$ contendo solo que foi analisado (Tabela 1). Plantas vigorosas e uniformes foram selecionadas após 1 mês e feito o desbaste nos vasos, onde foram deixadas apenas duas plantas por vaso. 
Tabela 1. Resultados da análise química do solo usado no experimento com guanxumas em casa-de-vegetação, Piracicaba, 1999.

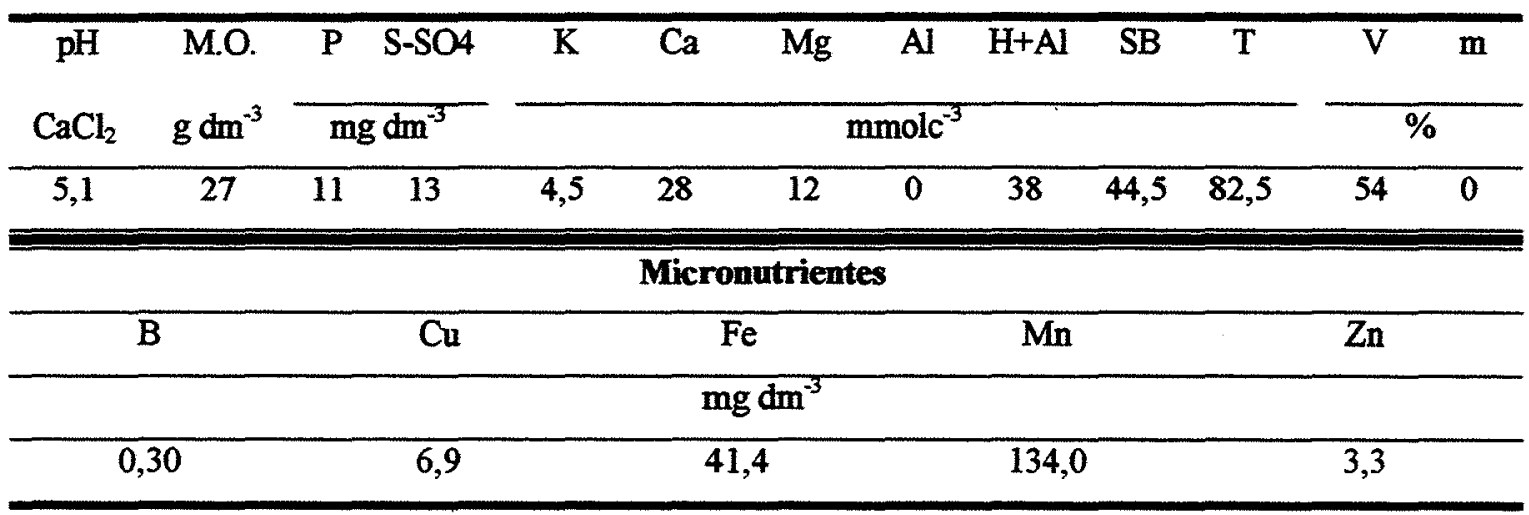

\subsubsection{Delineamento experimental e tratamentos}

O delineamento experimental utilizado foi de blocos casualizados com 4 repetições em esquema fatorial $6 \mathrm{X} 4$, sendo 3 herbicidas com duas doses e 3 tratamentos com adjuvantes, mais 1 tratamento sem adjuvante. Os herbicidas utilizados foram o 2,4-D + picloram $\left(240\right.$ g.L $L^{-1}, 64$ g.L $\left.L^{-1}\right)$, o 2,4-D + picloram $\left(120\right.$ g. $\left.\mathrm{L}^{-1}, 40 \mathrm{~g} . \mathrm{L}^{-1}\right)$ e o fluroxipir + picloram, com dose comercial e meia dose e os adjuvantes Agral, Silwet L-77 e Joint, todos em concentração de $0,1 \% \mathrm{v} / \mathrm{v}$, totalizando 25 tratamentos, esquematizados na Tabela 2. 
Tabela 2. Tratamentos utilizados em casa-de-vegetação com respectivas doses. Piracicaba 1999.

\begin{tabular}{|c|c|c|c|}
\hline \multirow[b]{2}{*}{$\begin{array}{l}\text { Número do } \\
\text { tratamento }\end{array}$} & \multicolumn{3}{|c|}{ Tratamentos } \\
\hline & $\begin{array}{l}\text { Herbicidas } \\
{\text { (p. c. })^{1}}\end{array}$ & $\begin{array}{l}\text { Adjuvantes } \\
0,1 \%(v / v) \\
\end{array}$ & $\begin{array}{c}\text { Dose } \\
\left(\mathrm{L} \mathrm{ha}^{-1}\right)\end{array}$ \\
\hline 1 & Testemunha ( $\mathrm{T}$ ) & & \\
\hline 2 & \multirow{8}{*}{$\begin{array}{c}\text { 2,4-D + picloram } \\
\left(240 \text { g.L } \mathrm{L}^{-1}, 64 \mathrm{~g} . \mathrm{L}^{-1}\right)\end{array}$} & Sem Adjuvante & \multirow{4}{*}{1,5} \\
\hline 3 & & Agral & \\
\hline 4 & & Silwet & \\
\hline 5 & & Joint & \\
\hline 6 & & Sem Adjuvante & \multirow{4}{*}{0,75} \\
\hline 7 & & Agral & \\
\hline 8 & & Silwet & \\
\hline 9 & & Joint & \\
\hline 10 & \multirow{8}{*}{$\begin{array}{c}2,4-\mathrm{D}+\text { picloram } \\
\left(120 \mathrm{~g} \cdot \mathrm{L}^{-1}, 40 \mathrm{~g} \cdot \mathrm{L}^{-1}\right)\end{array}$} & Sem Adjuvante & \multirow{4}{*}{2,0} \\
\hline 11 & & Agral & \\
\hline 12 & & Silwet & \\
\hline 13 & & Joint & \\
\hline 14 & & Sem Adjuvante & \multirow{4}{*}{1,0} \\
\hline 15 & & Agral & \\
\hline 16 & & Silwet & \\
\hline 17 & & Joint & \\
\hline 18 & \multirow{8}{*}{$\begin{array}{l}\text { fluroxipir + } \\
\text { picloram }\end{array}$} & Sem Adjuvante & \multirow{4}{*}{1,5} \\
\hline 19 & & Agral & \\
\hline 20 & & Silwet & \\
\hline 21 & & Joint & \\
\hline 22 & & Sem Adjuvante & \multirow{4}{*}{0,75} \\
\hline 23 & & Agral & \\
\hline 24 & & Silwet & \\
\hline 25 & & Joint & \\
\hline
\end{tabular}

Troduto comercial 


\subsubsection{Herbicidas e adjuvantes utilizados:}

2,4-D + picloram (240 g.L $L^{-1}, 64$ g.L $\left.{ }^{-1}\right)$ : herbicida sistêmico de ação seletiva, sendo o picloram derivado do ácido picolínico e o 2,4-D do grupo dos fenoxiacéticos. Nomes químicos: a) sal trietanolamina do ácido 4-amino-3,5,6tricloropicolínico. b) sal trietanolamina do açido 2,4-D diclorofenoxiacético. Nomes comuns: a) Picloram, sal trietanolamina. b) 2,4-D sal trietanolamina. Nome comercial : Tordon. Composição química: 2,4-D amina, 240 g.L $\mathrm{L}^{-1}$ e. picloram, 64 g.L ${ }^{-1}$. Formulação: solução aquosa concentrada. Classe toxicológica I

2,4-D + picloram (120 g.L $L^{-1}, 40$ g. $\left.L^{-1}\right)$ : herbicida sistêmico de ação seletiva, sendo o picloram derivado do ácido picolínico e o 2,4-D do grupo dos fenoxiacéticos. Nomes químicos: a) sal trietanolamina do ácido 4-amino-3,5,6tricloropicolínico. b) sal trietanolamina do açido 2,4-D diclorofenoxiacético. Nomes comuns: a) Picloram, sal trietanolamina. b) 2,4-D sal trietanolamina. Nome comercial: Mannejo. Composição química: 2,4-D amina, 120 g. $L^{-1}$ e picloram, 40 g. $L^{-1}$. Formulação: concentrado solúvel. Classe toxicológica I.

Fluroxipir + picloram: herbicida sistêmico de ação seletiva, sendo o picloram derivado do ácido picolínico e o fluroxipir do grupo químico das piridinas. Nome comercial: Plenum. Composição química: 80 g. $\mathrm{L}^{-1}$ equivalente ácido de fluroxipir mhe e 80 g. $\mathrm{L}^{-1}$ equivalente ácido de picloram. Formulação: microemulsão. Classe toxicológica: II.

Silwet L-77 Ag : surfactante siliconado, espalhante adesivo composto à base de trisiloxanos ligados a uma cadeia de óxido de polialquileno. Dispersível em água. Joint oil: óleo mineral, mistura de hidrocarbonetos parafinicos, cicloparafínicos e aromáticos saturados e insaturados, provenientes da destilação do petróleo. 
Adjuvante do grupo dos hidrocarbonetos. Formulação do tipo concentrado emulsionável com classe toxicológica IV (Andrei, 1999).

Agral: surfactante não iônico, nonil fenoxi poli (etilenoxi) etanol. Espalhante adesivo não-iônico, que pode ser adicionado a qualquer herbicida. Melhora a distribuição de defensivos, propiciando a formação de uma película protetora uniforme. Especialmente necessário quando o defensivo agrícola for aplicado sobre superficies, como folhas lisas, cerosas ou pilosas. Formulação do tipo solução aquosa concentrada com classe toxicológica IV (Andrei, 1999).

\subsubsection{Aplicação dos tratamentos}

Os tratamentos foram aplicados em 08/01/99, 68 dias depois da semeadura, quando as plantas apresentavam em média $8 \mathrm{~cm}$ de altura e de 8 a 10 pares de folhas. A aplicação foi realizada na câmara de aplicação com barra móvel, e pressão constante de $4,00 \mathrm{~kg} \cdot \mathrm{cm}^{-2}$ e com bicos Teejet 110.02 em leque. O volume de calda aplicado foi equivalente a $300 \mathrm{~L} \cdot \mathrm{ha}^{-1}$.

\subsubsection{Avaliação do experimento}

O efeito dos tratamentos foi avaliado pela escala de avaliação visual de fitotoxicidade de herbicidas sobre plantas, proposta pela Europeam Weed Research Council (EWRC), com escala variando de 1 a 9, indicando ausência de sintomas e danos totais respectivamente. As avaliações foram feitas aos 7, 14, 28 e 56 dias após a aplicação. Após 56 dias da aplicação (56 DAA), foi determinada 
a biomassa recém colhida e após secagem em estufa por dois dias a biomassa seca foi também determinada em balança de precisão.

\subsubsection{Análise estatística}

Os resultados obtidos foram submetidos a análise de variância, aplicandose $\mathrm{o}$ teste $\mathrm{F}$ ao nível de $5 \%$ para testar os efeitos entre os herbicidas e adjuvantes. A comparação das médias foi realizada pelo teste de Tukey a $5 \%$. 


\section{RESULTADOS E DISCUSSÃO}

4.1 Características morfológicas da cutícula foliar de três espécies de guanxuma

\subsubsection{Determinação da espessura da cutícula}

Solereder (1908) cita que a familia Malvaceae apresenta uma variação muito grande em termos da espessura de cutícula sendo que a maioria das espécies apresentam cutícula delgada. As três espécies aqui analisadas apresentaram essa característica de cutícula delgada sem possibilidade de terem sido medidas em microscópio de luz com a ocular micrométrica na escala de $0,0033 \mathrm{~mm}$.

\subsubsection{Caracterização da superfície foliar com o uso da Microscopia Eletrônica de Varredura (MEV)}

Para cada superficie das três espécies estudadas são apresentadas fotografias através do uso da microscopia eletrônica de varredura (MEV), onde cada figura mostra uma característica particular da espécie como quantidade de tricomas e caracterização da cutícula. 
Segundo Mauseth (1988), as dicotiledôneas possuem tipicamente as paredes anticlinais das células epidérmicas com aspectos sinuosos e ondulados. As espécies Sida rhombifolia, Sida glaziovii e Sida cordifolia mostraram claramente essa característica (Figuras 2, 3 e 4).

A superficie adaxial de Sida rhombifolia apresentou tricomas estelares e simples em pouca quantidade, tanto curtos como longos e glandulares e apresentou também estômatos dispersos de forma aleatória na superficie foliar (Figura 2). Metcalfe \& Chalk (1979) deram nomes mais descritivos a diversos tipos de estômatos e na família Malvaceae o estômato que ocorre é do tipo anomocítico ou de células irregulares, onde as células circundantes são em número indefinido e não diferem das outras células epidérmicas (Figura 7).

A principal característica observada na superficie adaxial de Sida rhombifolia foi a presença abundante de ceras epicuticulares estriadas com orientação randômica (Figura 7 e 10). Essas ceras também estão presentes na superficie abaxial da espécie, que também apresentou grande número de tricomas glandulares e a presença de tricomas estelares (Figura 12).

A espécie Sida glaziovii apresentou grande ocorrência de tricomas estelares, que foi a característica mais marcante nessa espécie tanto na superfície adaxial como na abaxial, sendo que nessa a superficie ficou quase oclusa (Figuras 3 e 13). Segundo Cutter (1986) é comum nessa família a ocorrência de vários tipos de tricomas na mesma espécie e a Sida glaziovii mostrou grande número também de tricomas glandulares de variadas estruturas (Figuras 6 e 15). $O$ mesmo autor cita que esses tricomas possuem um pedúnculo e uma cabeça; o pedúnculo pode ser unicelular ou multicelular e, pode mesmo ter várias fileiras de células. A cabeça, que é a parte secretora, também pode ser unicelular ou multicelular. Uma estrutura semelhante à cutícula cobre a(s) célula(s) da cabeça e a secreção é acumulada na bolsa formada entre a(s) célula(s) e a cutícula. 


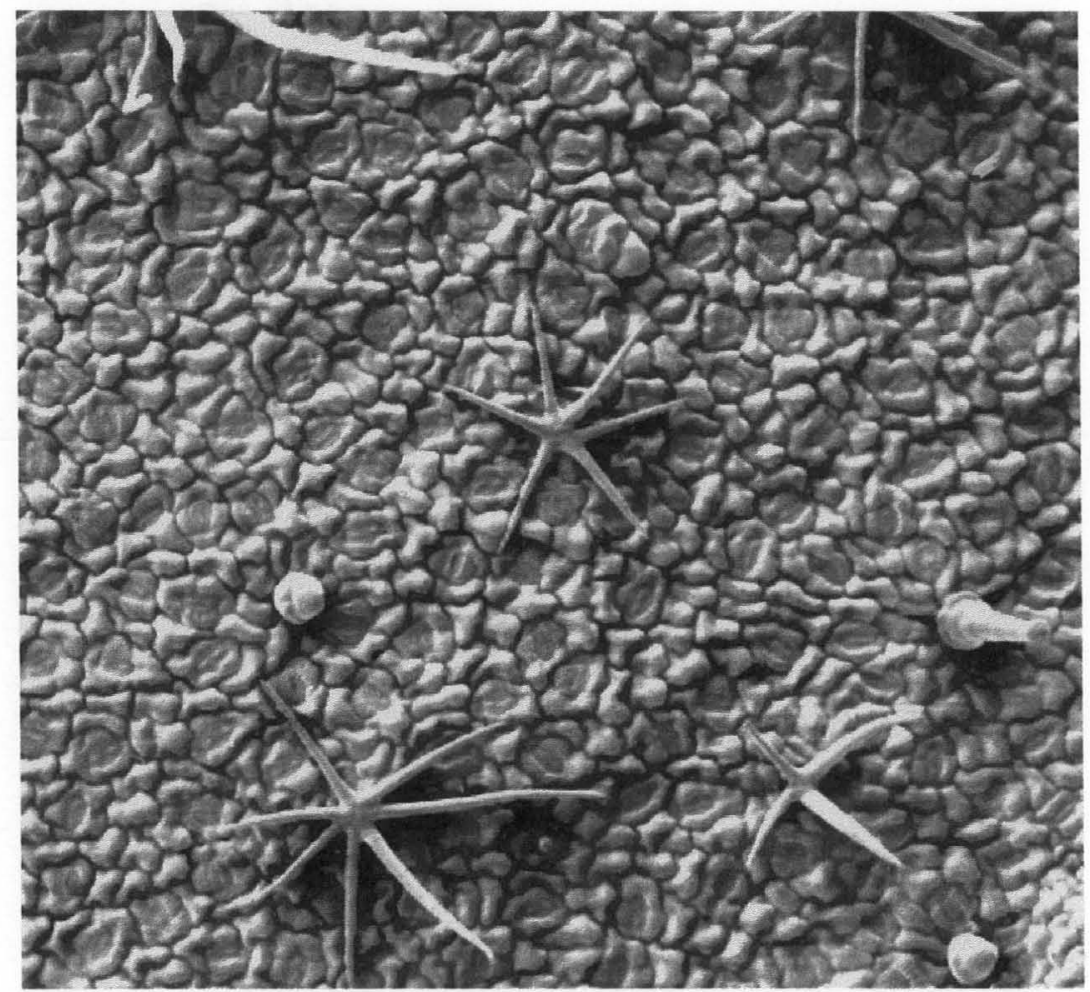

Figura 2 - Superfície adaxial da folha de Sida rhombifolia. Vista geral da epiderme. Escala: 200X/50um.

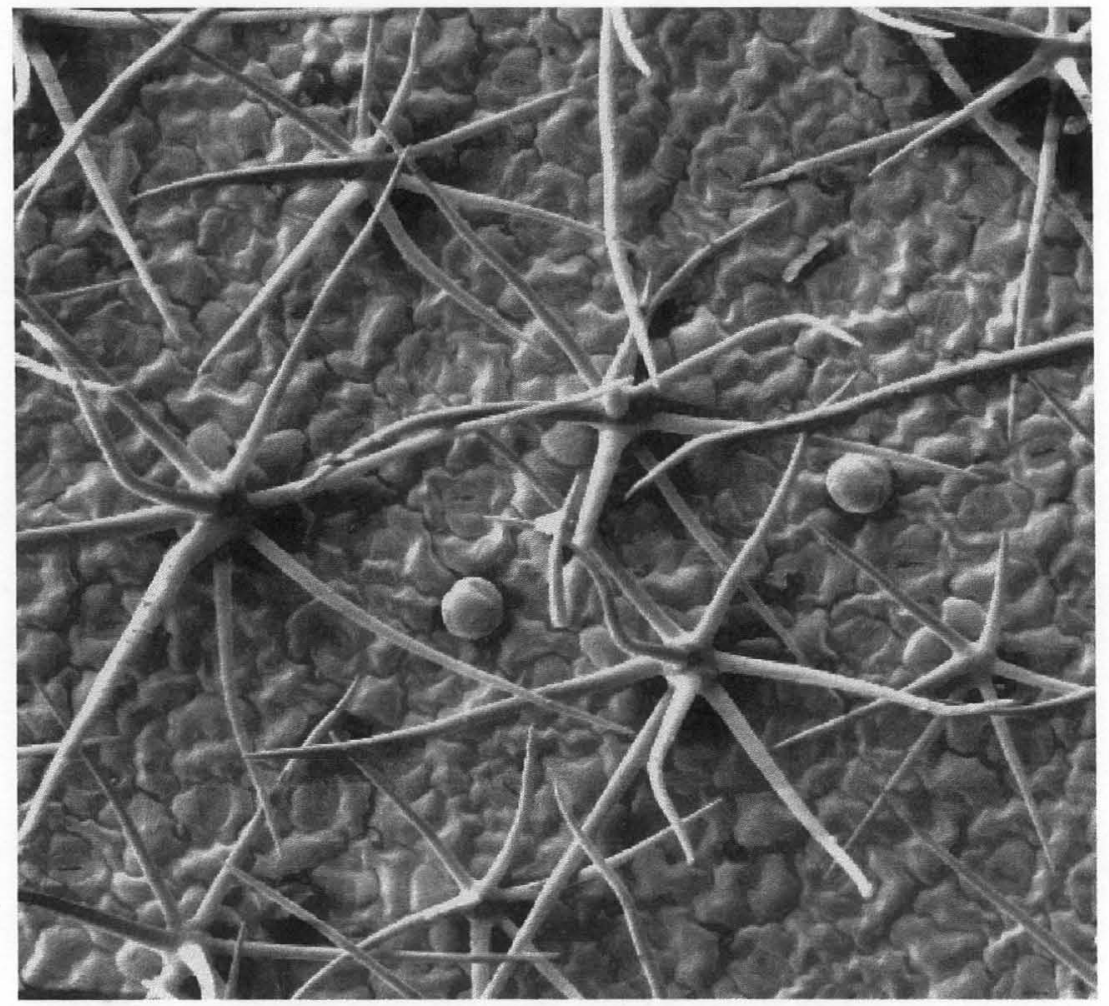

Figura 3 - Superfície adaxial da folha de Sida glaziovii. Vista geral da epiderme. Escala: 200X/50um. 


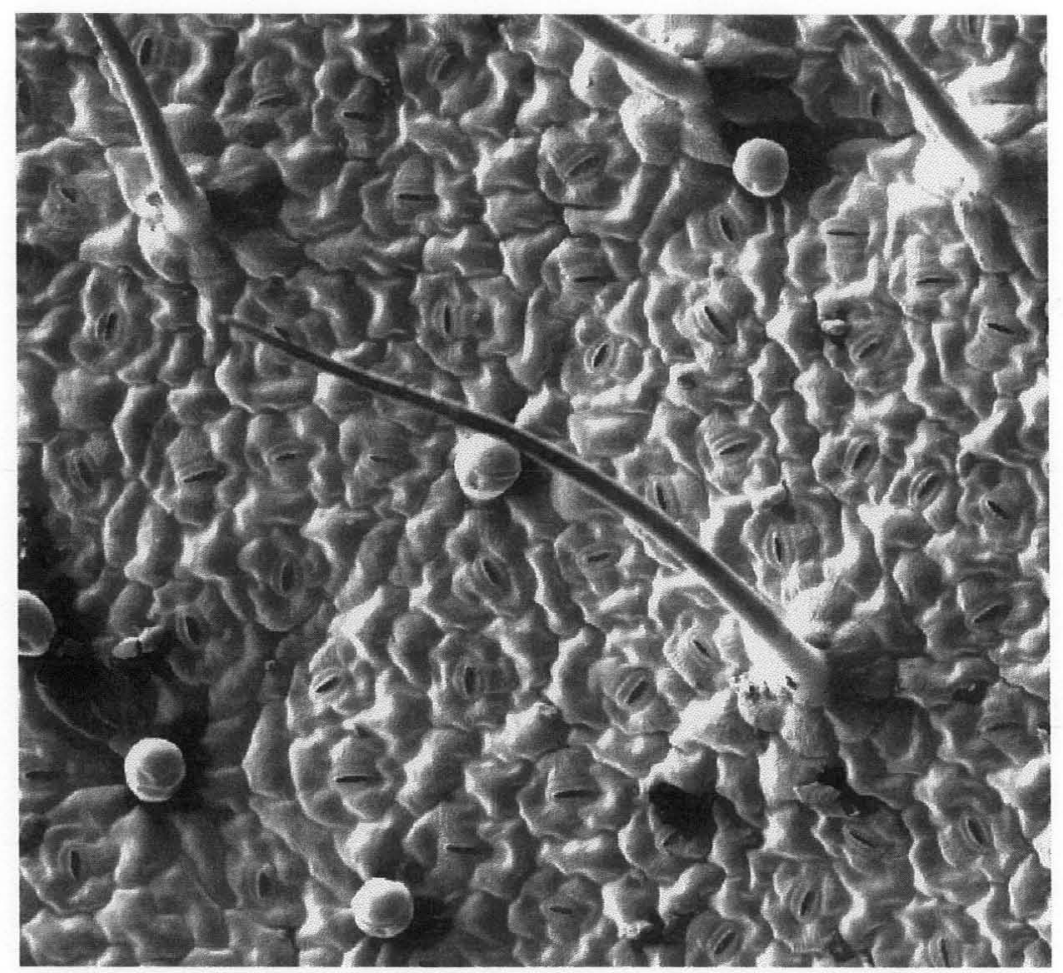

Figura 4 - Superfície adaxial da folha de Sida cordifolia. Vista geral da epiderme.

Escala: 200X/50um.

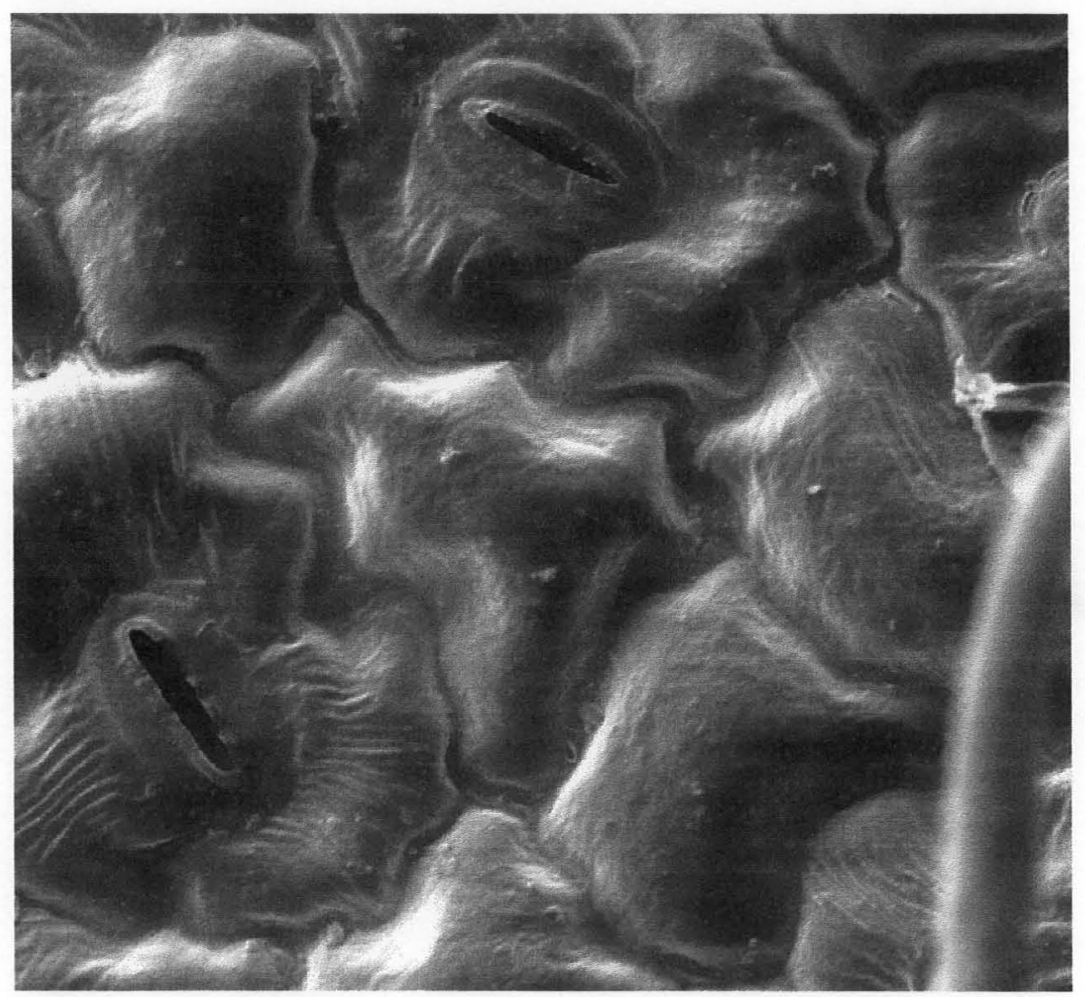

Figura 5 - Superfície adaxial da folha de Sida cordifolia. Cutícula plana.

Escala:1000X/10um. 


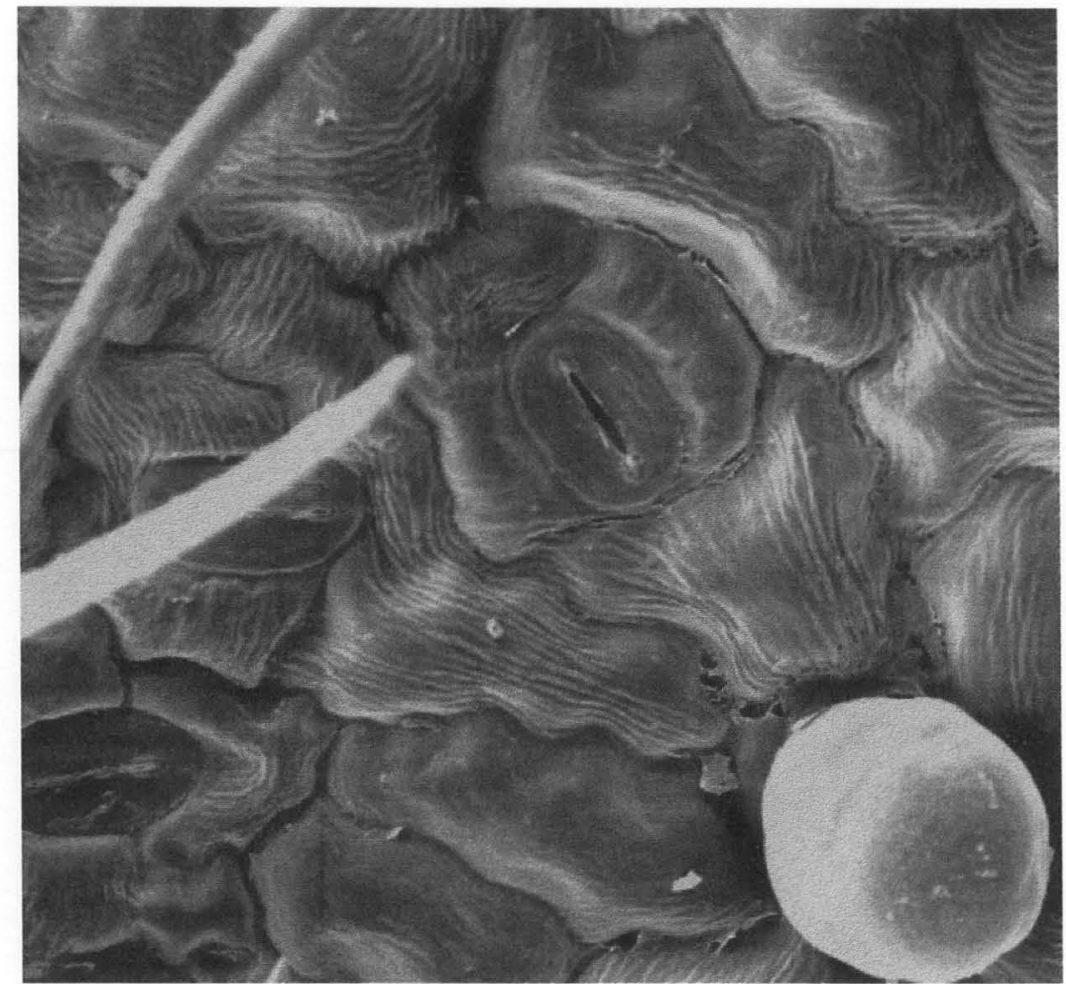

Figura 6 - Superfície adaxial da folha de Sida glaziovii. Paredes anticlinais sinuosas. Tricoma glandular e Estômato anomocítico. Escala: 1000X/10um.

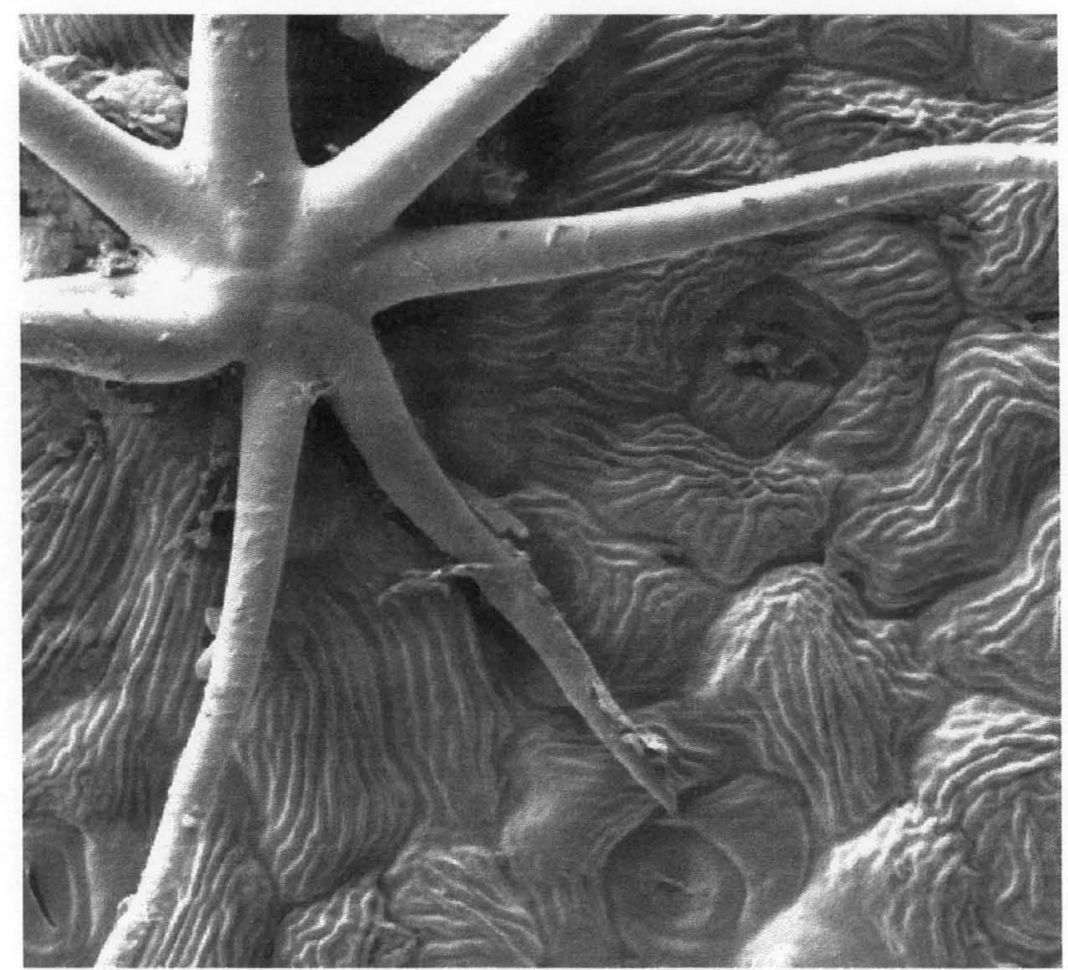

Figura 7 - Superfície adaxial da folha de Sida rhombifolia. Paredes anticlinais sinuosas. Tricoma estelar e Estômato anomocítico. Escala: 1000X/10um. 
Em relação à sua ornamentação cuticular, essa espécie apresentou ceras epicuticulares também estriadas mas não tão evidentes como na Sida rhombifolia. Os estômatos também são do tipo anomocíticos e se encontram um pouco abaixo da superficie (Figuras 6 e 11).

A espécie Sida cordifolia foi das três espécies a que mostrou menor quantidade de tricomas, possuindo na superficie adaxial predominantemente tricomas simples e/ou com duas ramificações e também tricomas glandulares simples e curtos (Figuras 8 e 16). A superfície abaxial apresentou abundância nos tricomas estelares, aparentando muita proximidade com a espécie Sida glaziovii (Figura 14).

A cutícula apresentou superficie plana e lisa sem o aspecto estriado das outras duas espécies analisadas (Figuras 5 e 9). Também apresenta estômatos anomocíticos, característico da família. Todas as espécies apresentaram estômatos em ambas a faces (superficie adaxial e abaxial).

Segundo Solereder (1908) a família Malvaceae é caracterizada por possuir tricomas estelares e organismos secretores com conteúdo mucilaginoso apesar de nem todos os membros da Família manifestarem essas características.

Foy \& Takeno (1992), estudando as superficies foliares de Sida spinosa,. comentam que as mesmas aparentam ser planas e lisas a olho nu. Porém, numerosos tricomas foram observados em ambos lados das folhas através do microscópio eletrônico de varredura. Harr et al. (1991) demonstram que diferentemente das três espécies aqui analisadas, a espécie Sida spinosa apresenta apenas tricomas simples e glandulares. 


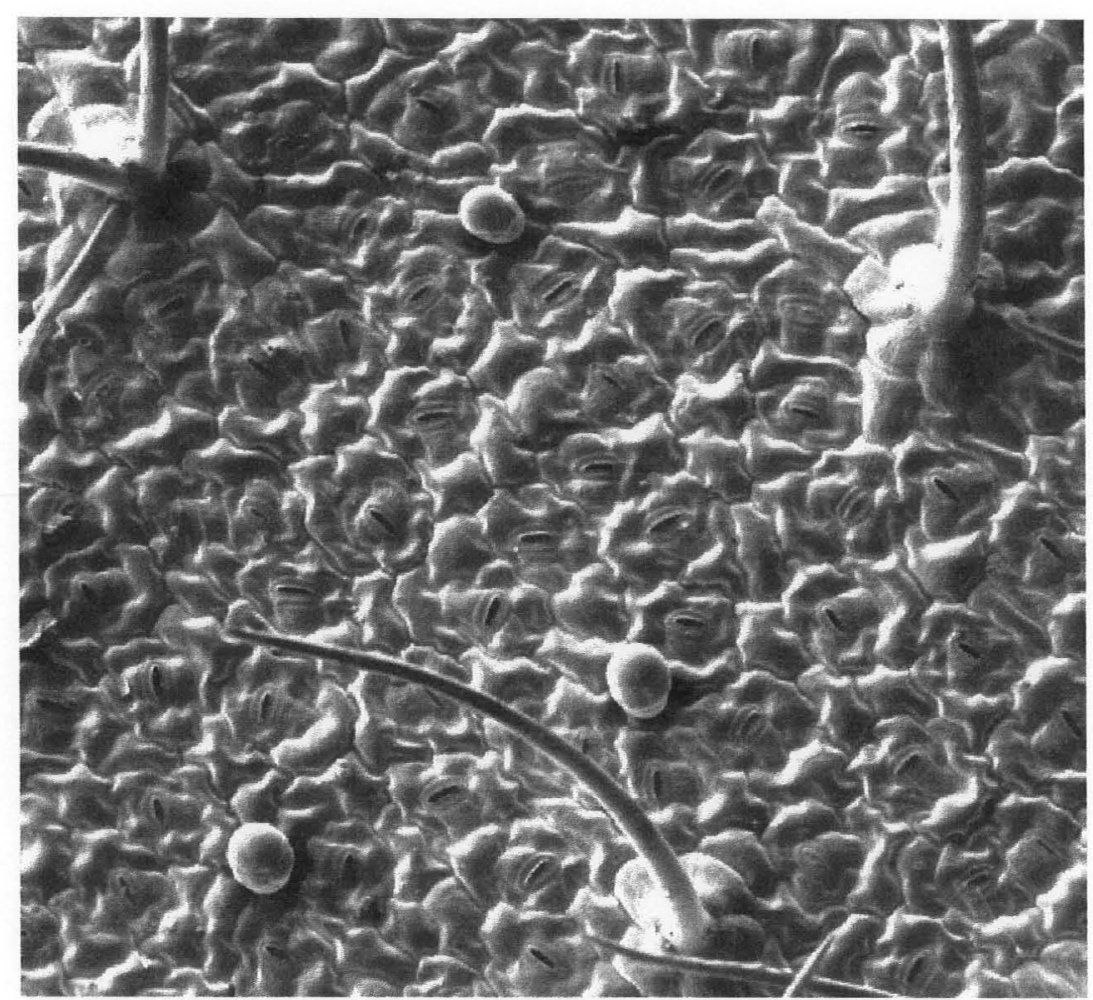

Figura 8 - Superfície adaxial da folha de Sida cordifolia. Vista geral da epiderme.

Escala: 200X/50um

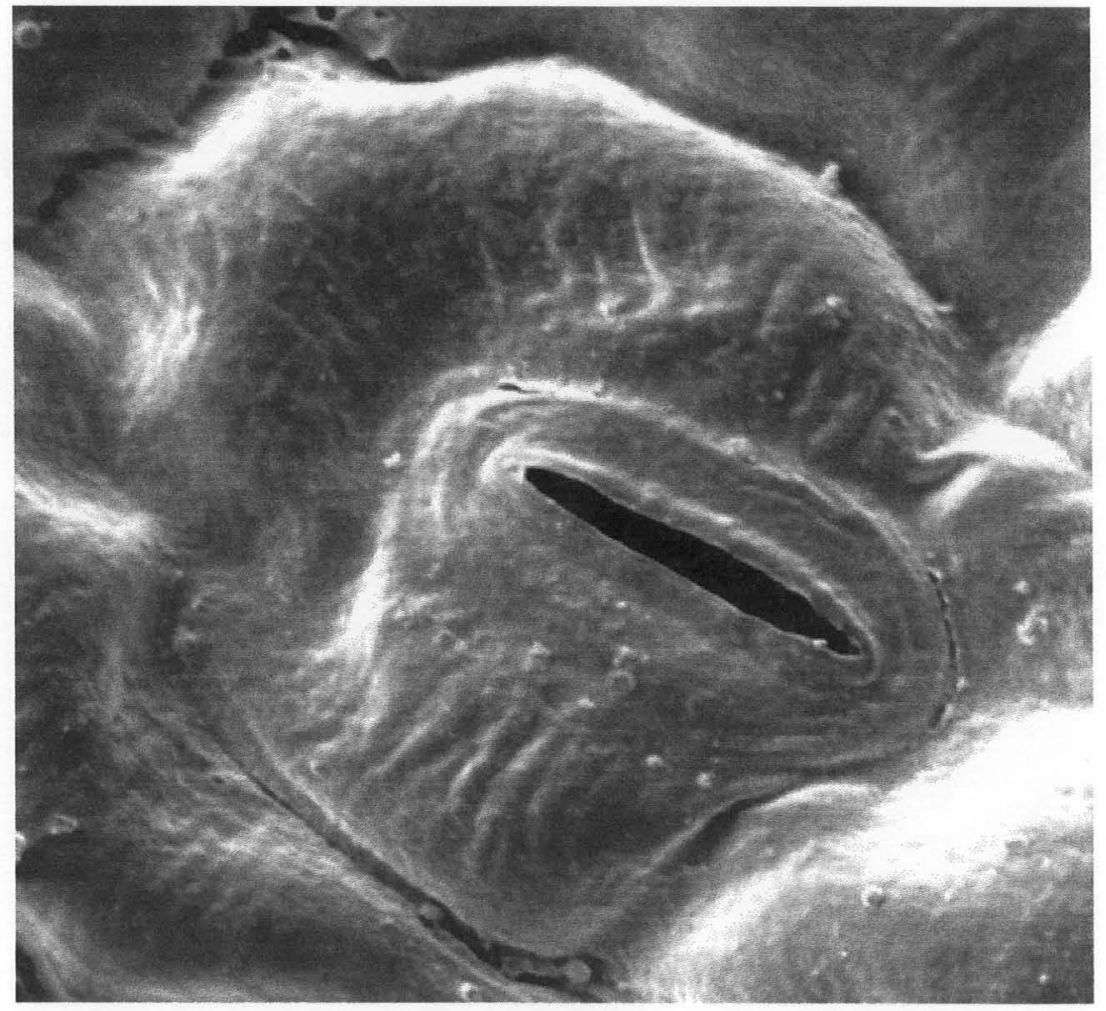

Figura 9 - Superfície adaxial da folha de Sida cordifolia. Detalhe do estômato e da superfície plana. Escala: $2000 \mathrm{X} / 5$ um. 


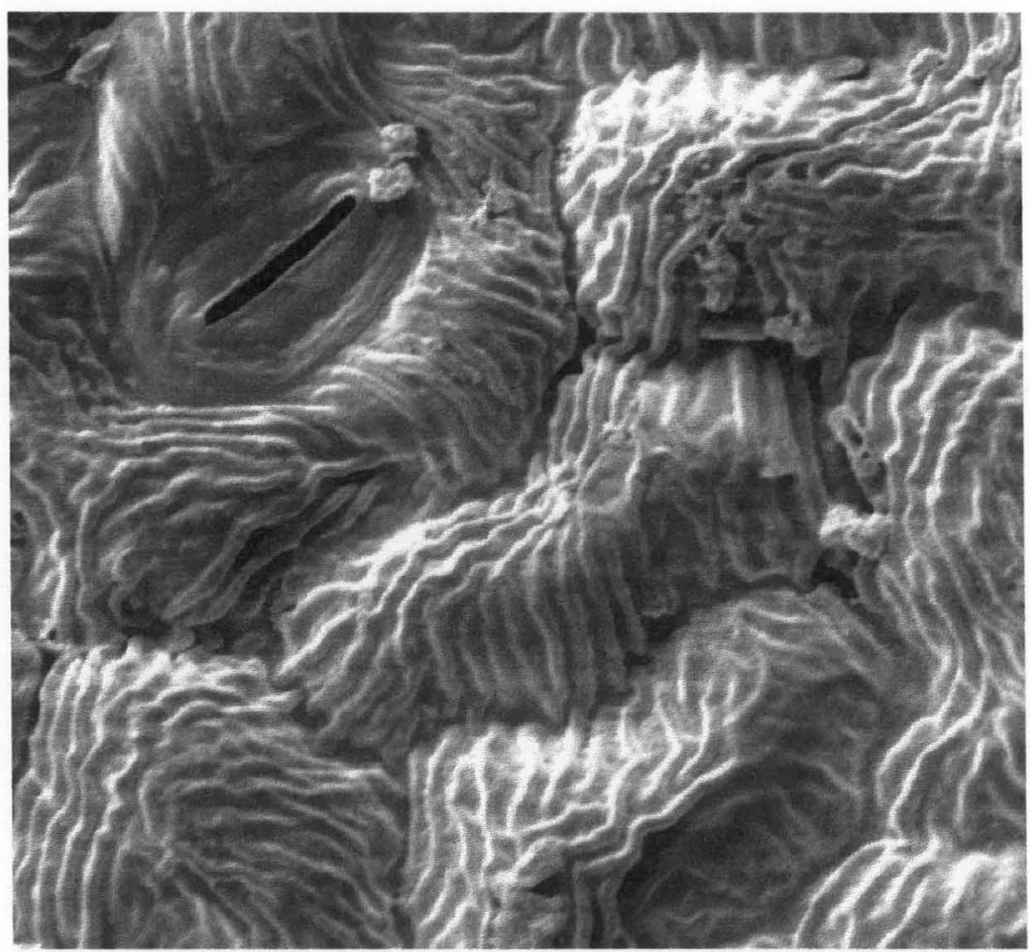

Figura 10 - Superfície adaxial da folha de Sida rhombifolia. Detalhe do estômato e da cutícula estriada. Escala: 2000X/5um.

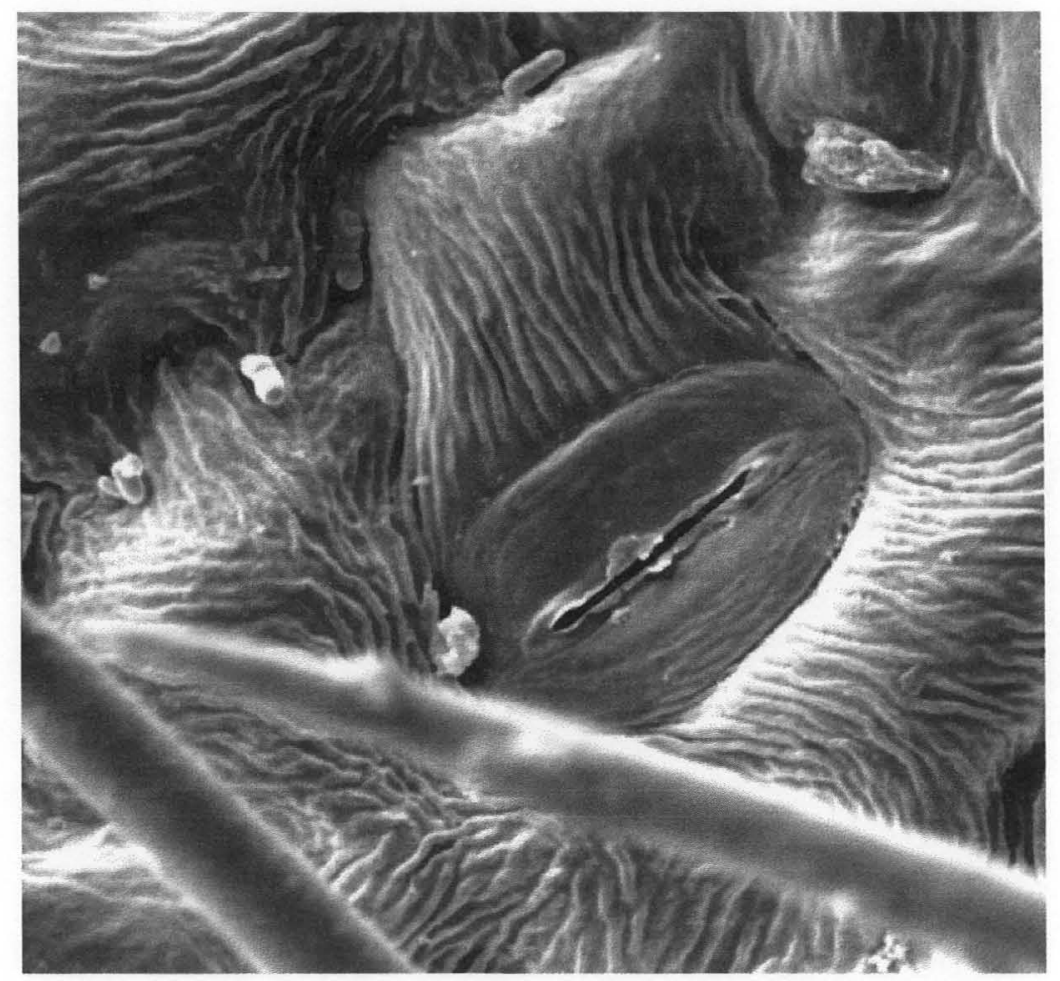

Figura 11 - Superfície adaxial da folha de Sida glaziovii. Detalhe do estômato e da cutícula estriada. Escala: 2000X/5um. 


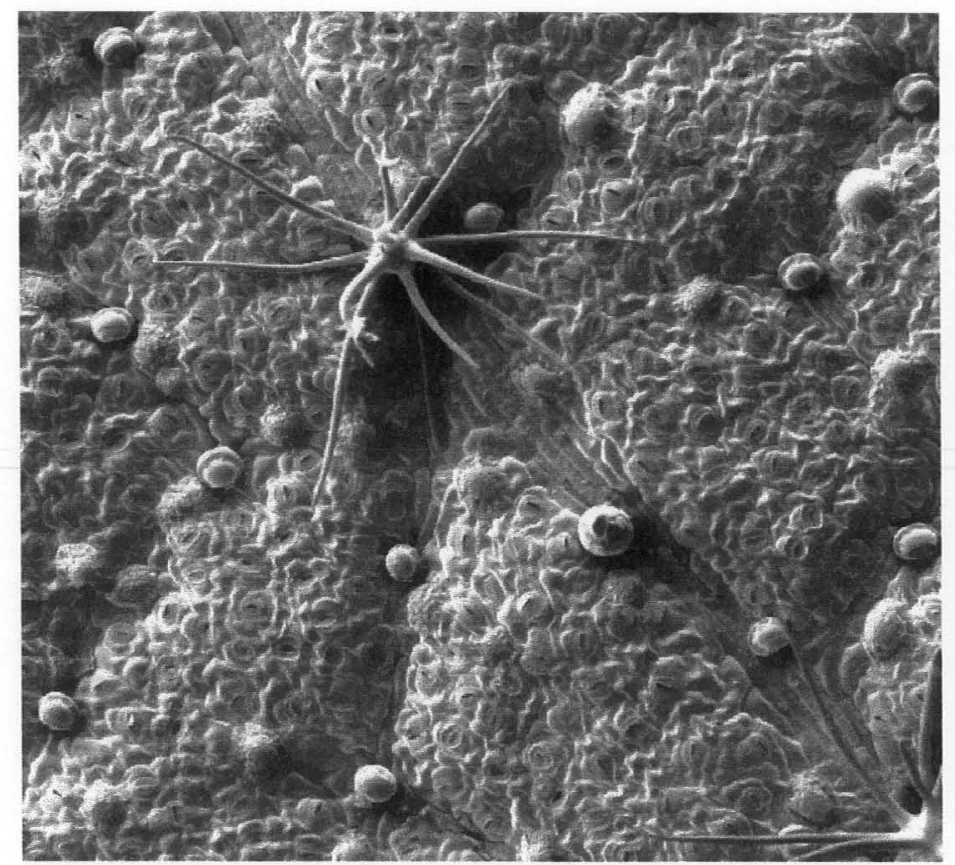

Figura 12 - Superfície abaxial da folha de Sida rhombifolia. Vista geral da epiderme. Detalhe dos tricomas. Escala: 200X/50 um.

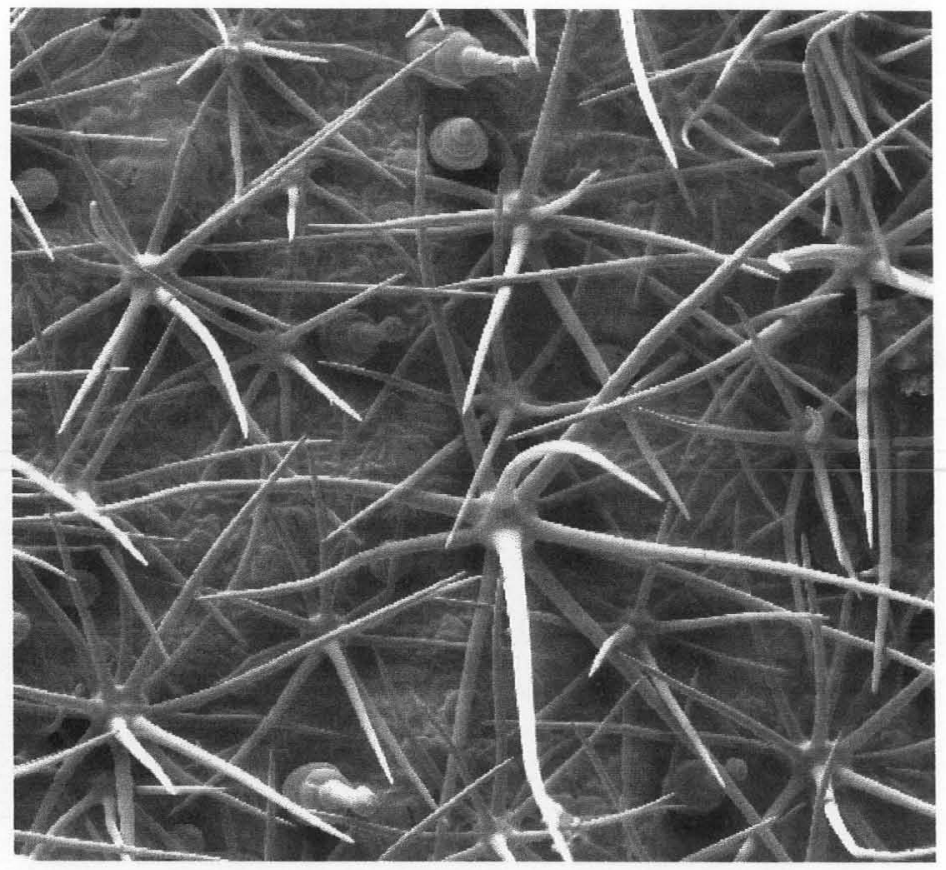

Figura 13 - Superfície abaxial da folha de Sida glaziovii. Vista geral da epiderme. Detalhe dos tricomas.

Escala: 200X/50 um.

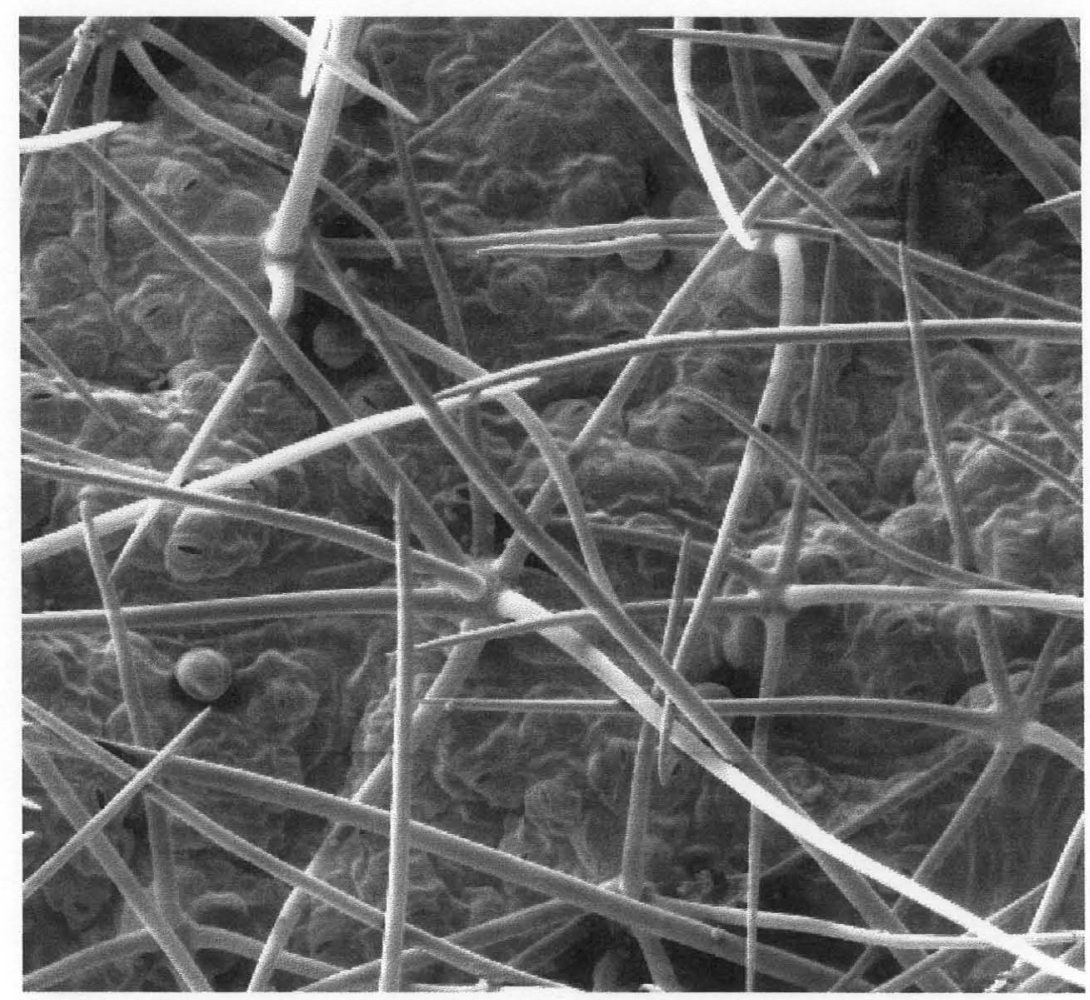

Figura 14 - Superfície abaxial da folha de Sida cordifolia. Vista geral da epiderme. Detalhe dos tricomas. Escala: 200X/50 um. 


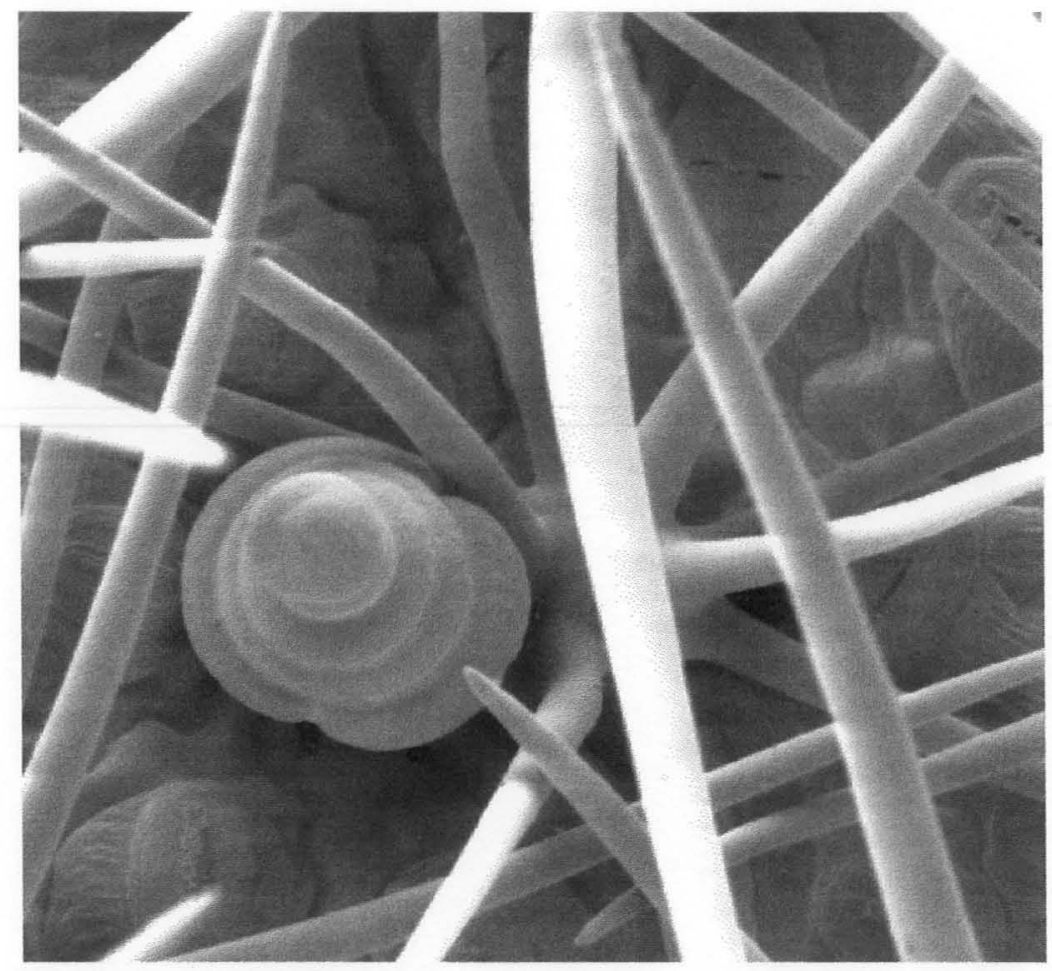

Figura 15 - Superfície abaxial da folha de Sida glaziovii. Detalhe de tricoma glandular e estelar. Escala: $1000 \mathrm{X} / 10 \mathrm{um}$.

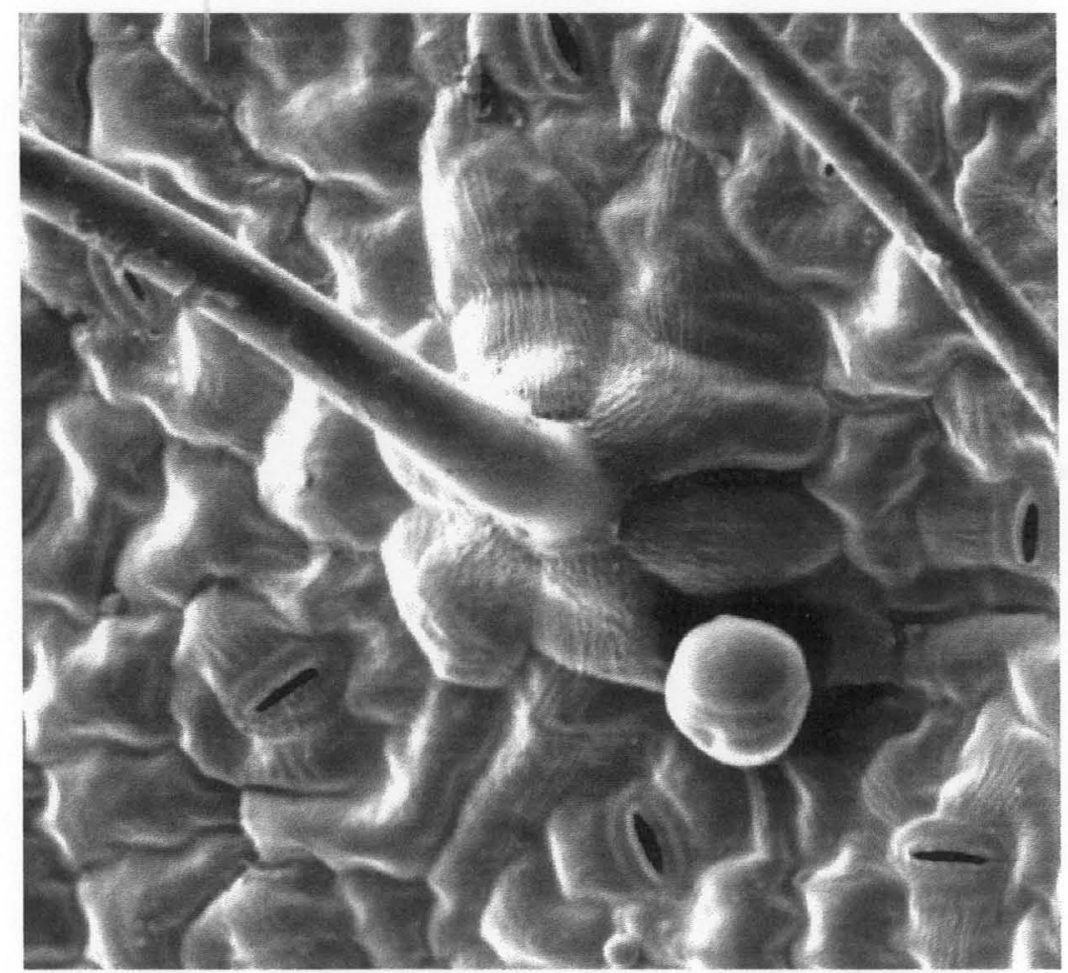

Figura 16 - Superficie adaxial da folha de Sida cordifolia. Detalhe de tricoma simples e glandular. Escala: 500X/20um. 


\subsection{Controle químico das espécies de guanxuma (Sida spp)}

\subsubsection{Efeito de adjuvantes no controle da espécie Sida rhombifolia}

Os resultados da primeira avaliação, sete dias após a aplicação (7 DAA) estão apresentados na Tabela 3, mostrando que os tratamentos aplicados causaram injúrias significativas em relação à testemunha na espécie Sida rhombifolia e cujos sintomas foram típicos dos herbicidas hormonais como epinastia, encurvamento do caule, ramos e pecíolos.

As maiores notas de fitotoxicidade foram obtidas com a aplicação da mistura dos herbicidas $2,4-\mathrm{D}+$ picloram $\left(120 \mathrm{~g} . \mathrm{L}^{-1}, 40 \mathrm{~g} . \mathrm{L}^{-1}\right)$ na dose de $2 \mathrm{~L}$ do produto comercial (p.c.).ha ${ }^{-1}$ em combinação com o adjuvante Silwet e o herbicida fluroxipir + picloram com o adjuvante Joint, sendo este o que apresentou a maior nota. Apesar disso, esses dois tratamentos só diferiram significativamente dos tratamentos com os herbicidas 2,4-D + picloram (240 g. $\mathrm{L}^{-1}, 64$ g. $\left.\mathrm{L}^{-1}\right)$ na dose de $0,75 \mathrm{~L}$ de p.c. ha ${ }^{-1}$ sem adjuvante e com o adjuvante Agral e do 2,4-D + picloram (120 g.L $\mathrm{L}^{-1}, 40$ g. $\left.\mathrm{L}^{-1}\right)$ na dose de $1,0 \mathrm{~L}$ p.c. ha ${ }^{-1} \mathrm{em}$ combinação com o adjuvante Joint.

A análise de variância, que comparou o efeito de herbicidas e adjuvantes mostrou não haver interação significativa entre esses dois fatores em nenhuma das quatro avaliações. Isto mostra que o efeito dos adjuvantes foi independente dos herbicidas e vice-versa, o que não significa que não houve efeito dos herbicidas ou mesmo dos adjuvantes (Tabela 4A). Na tabela 4, em média, os dados da primeira avaliação mostram maiores índices de controle, com a mistura dos herbicidas fluroxipir + picloram na doses de $1,5 \mathrm{~L}$ e $0,75 \mathrm{~L}$ de p.c. $\mathrm{ha}^{-1}$ diferindo significativamente da mistura $2,4-\mathrm{D}+$ picloram $\left(240\right.$ g.L $\mathrm{L}^{-1}, 64$ g.L $\left.\mathrm{L}^{-1}\right)$ a 
$0,75 \mathrm{~L}$ de p.c. $\mathrm{ha}^{-1}$. Essa mesma tabela demonstra que o adjuvante Silwet apresentou melhor eficácia diferindo significativamente do adjuvante Joint e do tratamento sem adjuvante.

Na segunda avaliação 14 DAA, como pode-se observar na Tabela 3 , a mistura dos herbicidas fluroxipir + picloram na dose de $1,5 \mathrm{~L}$ de p.c. $\mathrm{ha}^{-1}$ obteve maiores notas de fitotoxicidade quando combinado com os adjuvantes Silwet ou Joint e diferiram significativamente apenas dos tratamentos com os herbicidas 2,4-D + picloram (240 g.L $\mathrm{L}^{-1}, 64$ g.L $\left.\mathrm{L}^{-1}\right)$ na dose de $0,75 \mathrm{~L}$ de p.c. $\mathrm{ha}^{-1}$ sem adjuvante e com o adjuvante Agral e do 2,4-D + picloram (120 g.L $\mathrm{L}^{-1}, 40$ g.L $\left.\mathrm{L}^{-1}\right)$ na dose de 1,0 L de p.c. ha $^{-1}$ em combinação com o adjuvante Joint, além da testemunha. A Tabela 5 mostra que a mistura dos herbicidas fluroxipir + picloram foi superior aos demais herbicidas só não diferindo do mesmo na dose de $0,75 \mathrm{~L}$ de p.c. ha $^{-1}$. Também o adjuvante Silwet difere significativamente do óleo mineral Joint e do tratamento sem adjuvante. 


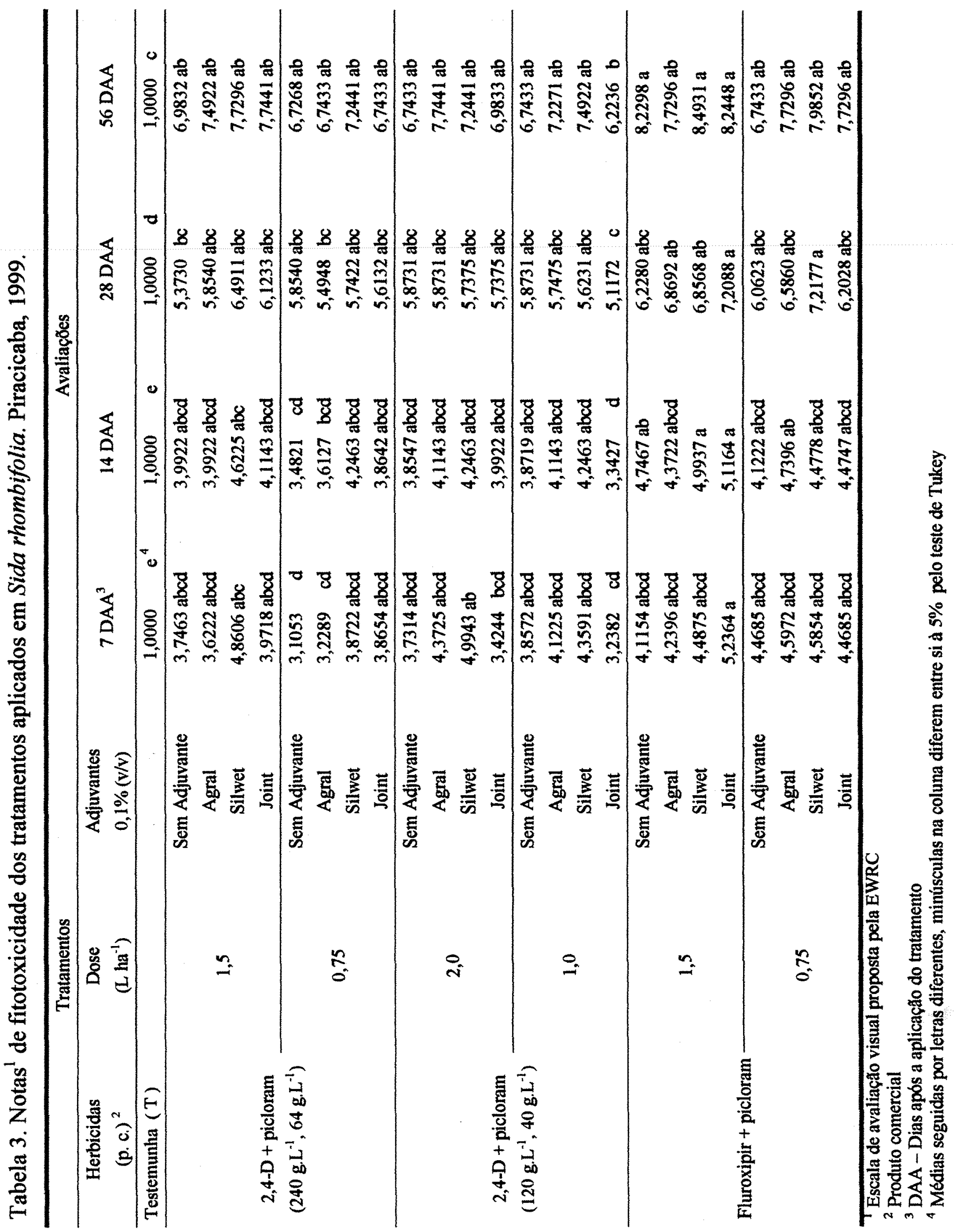


Tabela 4. Médias da primeira avaliação (7 DAA) da espécie Sida rhombifolia considerando o esquema fatorial. Piracicaba, 1999.

\begin{tabular}{|c|c|c|c|c|c|c|}
\hline \multirow{2}{*}{$\begin{array}{c}\text { Herbicida } \\
\text { (p.c.) }\end{array}$} & \multirow{2}{*}{$\begin{array}{l}\text { Dose } \\
\left(\mathrm{L} \mathrm{ha}^{-1}\right)\end{array}$} & \multirow{2}{*}{$\begin{array}{c}\text { Sem } \\
\text { Adjuvante }\end{array}$} & \multicolumn{3}{|c|}{ Adjuvante } & \multirow{2}{*}{ Média } \\
\hline & & & Agral & Silwet & Joint & \\
\hline 2,4-D + picloram & 1,5 & $3,75^{*}$ & 3,62 & 4,86 & 3,97 & $4,04 a b$ \\
\hline$\left(240\right.$ g.L. ${ }^{-1}, 64$ g. $\left.L^{-1}\right)$ & 0,75 & 3,11 & 3,23 & 3,57 & 3,87 & $3,51 \mathrm{~b}$ \\
\hline $2,4-D+$ picloram & 2,0 & 3,73 & 4,37 & 4,99 & 3,42 & $4,11 \mathrm{ab}$ \\
\hline$\left(120\right.$ g.L $\mathrm{L}^{-1}, 40$ g. $\left.\mathrm{L}^{-1}\right)$ & 1,0 & 3,86 & 4,12 & 4,36 & 3,24 & $3,88 \mathrm{ab}$ \\
\hline \multirow{2}{*}{ fluroxipir + picloram } & 1,5 & 4,12 & 4,24 & 4,49 & 5,24 & $4,51 \mathrm{a}$ \\
\hline & 0,75 & 4,46 & 4,60 & 4,59 & 4,47 & $4,53 \mathrm{a}$ \\
\hline Média & & $3,83 \mathrm{~B}$ & $4,02 \mathrm{AB}$ & $4,52 \mathrm{~A}$ & $4,01 \mathrm{~B}$ & \\
\hline
\end{tabular}

D.M.S. = Diferença mínima significativa para comparação de (1) herbicidas e (2) adjuvantes.

D.M.S.(1) $=0,16 ;$ D.M.S. $(2)=0,12$

C. $V .=7,07 \%$

*Dados transformados segundo $\sqrt{x+0,5}$

Médias seguidas por letras diferentes, maiúsculas na linha e minúsculas na coluna diferem entre si à $5 \%$ pelo teste de Tukey

Tabela 5. Médias da segunda avaliação (14 DAA) da espécie Sida rhombifolia considerando o esquema fatorial. Piracicaba, 1999.

\begin{tabular}{|c|c|c|c|c|c|c|}
\hline \multirow{2}{*}{$\begin{array}{c}\text { Herbicida } \\
\text { (p.c.) }\end{array}$} & \multirow{2}{*}{$\begin{array}{c}\text { Dose } \\
\left(\mathrm{L} \mathrm{ha}^{-1}\right)\end{array}$} & \multirow{2}{*}{$\begin{array}{c}\text { Sem } \\
\text { Adjuvante }\end{array}$} & \multicolumn{3}{|c|}{ Adjuvante } & \multirow{2}{*}{ Média } \\
\hline & & & Agral & Silwet & Joint & \\
\hline 2,4-D + picloram & 1,5 & $3,99^{*}$ & 3,99 & 4,62 & 4,12 & 4,18 bc \\
\hline$\left(240\right.$ g.L $L^{-1}, 64$ g.L $\left.L^{-1}\right)$ & 0,75 & 3,48 & 3,61 & 4,25 & 3,86 & 3,80 \\
\hline 2,4-D + picloram & 2,0 & 3,85 & 4,11 & 4,25 & 3,99 & 4,05 bc \\
\hline$\left(120\right.$ g.L $L^{-1}, 40$ g.L $\left.L^{-1}\right)$ & 1,0 & 3,87 & 4,11 & 4,25 & 3,25 & 3,89 bc \\
\hline \multirow{2}{*}{ fluroxipir + picloram } & 1,5 & 4,75 & 4,37 & 4,99 & 5,11 & $4,80 \mathrm{a}$ \\
\hline & 0,75 & 4,12 & 4,74 & 4,48 & 3,97 & $4,33 \mathrm{ab}$ \\
\hline Média & & $4,00 \mathrm{~B}$ & $4,15 \mathrm{AB}$ & $4,47 \mathrm{~A}$ & $4,05 \mathrm{~B}$ & \\
\hline
\end{tabular}

D.M.S. = Diferença mínima significativa para comparação de (1) herbicidas e (2) adjuvantes.

D.M.S. $(1)=0,12$; D.M.S. $(2)=0,09$

C.V. $=5,69 \%$

"Dados transformados segundo $\sqrt{x+0,5}$

Médias seguidas por letras diferentes, maiúsculas na linha e minúsculas na coluna diferem entre si à $5 \%$ pelo teste de Tukey 
Na terceira avaliação, 28 DAA a mistura dos herbicidas fluroxipir + picloram na dose de $1,5 \mathrm{~L}$ de p.c. ha $^{-1}$ com o adjuvante Joint e na dose de $0,75 \mathrm{~L}$ de p.c. ha $^{-1}$ com o adjuvante Silwet apresentam maiores notas e diferem significativamente dos tratamentos das misturas 2,4-D + picloram (240 g.L ${ }^{-1}, 64$ g. $\left.\mathrm{L}^{-1}\right)$ na dose de $1,5 \mathrm{~L}$ de p.c. ha $^{-1}$ sem adjuvante, $2,4-\mathrm{D}+$ picloram $\left(240\right.$ g. $\mathrm{L}^{-1}, 64$ g. $\left.\mathrm{L}^{-1}\right)$ na dose de 0,75 L de p.c. ha $^{-1}$ com Agral e da mistura 2,4-D + picloram (120 g. $\mathrm{L}^{-1}, 40$ g. $\mathrm{L}^{-1}$ ) na dose de $1,0 \mathrm{~L}$ de p.c. ha $^{-1}$ com o adjuvante Joint (Tabela 3). A Tabela 6 mostra que na média o herbicida fluroxipir + picloram nas duas doses apresentam maiores notas de fitotoxicidade em relação aos demais apesar desse herbicida na dose de $0,75 \mathrm{~L}$ de p.c. ha ${ }^{-1}$ não diferir significativamente da mistura 2,4-D + picloram $\left(240\right.$ g. $\mathrm{L}^{-1}, 64$ g. $\left.\mathrm{L}^{-1}\right)$ na dose de $1,5 \mathrm{~L}$ de p.c. $\mathrm{ha}^{-1}$. Entre os adjuvantes na média não houve diferença significativa entre os tratamentos.

Tabela 6. Médias da terceira avaliação (28 DAA) da espécie Sida rhombifolia considerando o esquema fatorial. Piracicaba, 1999.

\begin{tabular}{|c|c|c|c|c|c|c|}
\hline \multirow{2}{*}{$\begin{array}{c}\text { Herbicida } \\
\text { (p.c.) }\end{array}$} & \multirow{2}{*}{$\begin{array}{c}\text { Dose } \\
\left(\mathrm{L} \mathrm{ha}^{-1}\right)\end{array}$} & \multirow{2}{*}{$\begin{array}{c}\text { Sem } \\
\text { Adjuvante }\end{array}$} & \multicolumn{3}{|c|}{ Adjuvante } & \multirow{2}{*}{ Média } \\
\hline & & & Agral & Silwet & Joint & \\
\hline 2,4-D + picloram & 1,5 & $5,37^{*}$ & 5,85 & 6,49 & 6,12 & $5,95 \mathrm{bc}$ \\
\hline$\left(240\right.$ g.L $L^{-1}, 64$ g.L $\left.L^{-1}\right)$ & 0,75 & 5,85 & 5,49 & 5,74 & 5,61 & 5,68 \\
\hline 2,4-D + picloram & 2,0 & 5,87 & 5,87 & 5,74 & 5,74 & $5,81 \quad \mathrm{c}$ \\
\hline$\left(120 \mathrm{~g} \cdot \mathrm{L}^{-1}, 40 \mathrm{~g} \cdot \mathrm{L}^{-1}\right)$ & 1,0 & 5,87 & 5,75 & 5,62 & 5,12 & $5,59 \mathrm{c}$ \\
\hline \multirow{2}{*}{ fluroxipir + picloram } & 1,5 & 6,23 & 6,87 & 6,86 & 7,21 & $6,79 a$ \\
\hline & 0,75 & 6,06 & 6,59 & 7,22 & 6,20 & $6,51 \mathrm{ab}$ \\
\hline Média & & $5,87 \mathrm{~A}$ & $6,06 \mathrm{~A}$ & $6,26 \mathrm{~A}$ & $5,98 \mathrm{~A}$ & \\
\hline
\end{tabular}

D.M.S. = Diferença mínima significativa para comparação de (1) herbicidas e (2) adjuvantes.

D.M.S. $(1)=0,13 ;$ D.M.S. $(2)=0,09$

C. $\mathrm{V}=4,77 \%$

*Dados transformados segundo $\sqrt{x+0,5}$

Médias seguidas por letras diferentes, maiúsculas na linha e minúsculas na coluna diferem entre si à $5 \%$ pelo teste de Tukey 
Os resultados da Tabela 3 também mostram que aos 56 DAA, a mistura dos herbicidas fluroxipir + picloram na dose de $1,5 \mathrm{~L}$ de p.c. $\mathrm{ha}^{-1}$ sem adjuvante $\mathrm{e}$ com os adjuvantes Silwet ou Joint apresentaram as maiores notas de fitotoxicidade mas só diferiram significativamente do tratamento com a mistura 2,4-D + picloram (120 g. $\mathrm{L}^{-1}, 40$ g. $\left.\mathrm{L}^{-1}\right)$ na dose de $1,0 \mathrm{~L}$ de p.c. $\mathrm{ha}^{-1}$ com o adjuvante Joint. Na Tabela 7 observa-se que o melhor tratamento foi a mistura fluroxipir + picloram, na dose de $1,5 \mathrm{~L}$ de p.c. $\mathrm{ha}^{-1}$ não havendo diferença significativa entre este e a mistura $2,4-D+$ picloram $\left(240\right.$ g.L $L^{-1}, 64$ g.L $\left.L^{-1}\right)$ na dose de $1,5 \mathrm{~L}$ de p.c. ha ${ }^{-1}$ e entre fluroxipir + picloram na dose de $0,75 \mathrm{~L}$ de p.c. $\mathrm{ha}^{-1}$. O adjuvante Silwet apresenta maior nota e difere significativamente só do tratamento sem adjuvante.

Tabela 7. Médias da quarta avaliação (56 DAA) da espécie Sida rhombifolia considerando o esquema fatorial. Piracicaba, 1999.

\begin{tabular}{|c|c|c|c|c|c|c|}
\hline \multirow{2}{*}{$\begin{array}{l}\text { Herbicida } \\
\text { (p.c.) }\end{array}$} & \multirow{2}{*}{$\begin{array}{c}\text { Dose } \\
\left(\mathrm{L} \mathrm{ha}^{-1}\right)\end{array}$} & \multirow{2}{*}{$\begin{array}{c}\text { Sem } \\
\text { Adjuvante }\end{array}$} & \multicolumn{3}{|c|}{ Adjuvante } & \multirow{2}{*}{ Média } \\
\hline & & & Agral & Silwet & Joint & \\
\hline 2,4-D + picloram & 1,5 & $6,98^{*}$ & 7,49 & 7,73 & 7,74 & $7,48 \mathrm{ab}$ \\
\hline$\left(240\right.$ g.L $L^{-1}, 64$ g.L $\left.L^{-1}\right)$ & 0,75 & 6,73 & 6,74 & 7,24 & 6,74 & $6,86 \mathrm{~b}$ \\
\hline \multirow{2}{*}{$\begin{array}{c}2,4-\mathrm{D}+\text { picloram } \\
\left(120 \mathrm{~g} . \mathrm{L}^{-1}, 40 \mathrm{~g} \cdot \mathrm{L}^{-1}\right)\end{array}$} & 2,0 & 6,74 & 7,74 & 7,24 & 6,98 & $7,17 \quad b$ \\
\hline & 1,0 & 6,74 & 7,23 & 7,49 & 6,22 & $6,91 \mathrm{~b}$ \\
\hline \multirow{2}{*}{ fluroxipir + picloram } & 1,5 & 8,23 & 7,73 & 8,49 & 8,24 & \multirow{2}{*}{$\begin{array}{l}8,17 \mathrm{a} \\
7,54 \mathrm{ab}\end{array}$} \\
\hline & 0,75 & 6,74 & 7,73 & 7,99 & 7,73 & \\
\hline \multicolumn{2}{|l|}{ Média } & $7,02 \mathrm{~B}$ & $7,44 \mathrm{AB}$ & $7,69 \mathrm{~A}$ & $7,26 \mathrm{AB}$ & \\
\hline \multicolumn{7}{|c|}{ D.M.S.= Diferença mínima significativa para comparação de (1) herbicidas e (2) adjuvantes. } \\
\hline \multicolumn{7}{|c|}{ D.M.S. $(1)=0,13 ;$ D.M.S. $(2)=0,09$} \\
\hline \multicolumn{7}{|l|}{ C. $V .=4,36 \%$} \\
\hline
\end{tabular}


Após 56 dias da aplicação, foi determinada a biomassa recém colhida e a biomassa seca e verifica-se que o tratamento $2,4-\mathrm{D}+$ picloram $\left(120 \mathrm{~g} . \mathrm{L}^{-1}, 40 \mathrm{~g}\right.$. $\mathrm{L}^{-1}$ ) na dose de $2,0 \mathrm{~L}$ de p.c. $\mathrm{ha}^{-1}$ na biomassa recém colhida, não diferiu significativamente da testemunha enquanto que todos os outros diferiram da testemunha mas, não diferiram entre si. $\mathrm{Na}$ biomassa seca todos apresentaram diferença em relação à testemunha mas, não diferiram entre si (Tabela 8). $\mathrm{Na}$ Tabela 9 observa-se que a mistura fluroxipir + picloram na dose de $0,75 \mathrm{~L}$ de p.c. $\mathrm{ha}^{-1}$ apresentou menor peso não diferindo significativamente de fluroxipir + picloram na dose de $1,5 \mathrm{~L}$ de p.c. ha $^{-1}$ e de 2,4-D + picloram $\left(240\right.$ g.L $\mathrm{L}^{-1}, 64$ g.L $\left.\mathrm{L}^{-1}\right)$ na dose de $1,5 \mathrm{~L}$ de p.c. ha ${ }^{-1}$. Entre os adjuvantes Silwet apresentou o menor peso mas não mostra diferença significativa entre os tratamentos com adjuvantes e o tratamento sem adjuvante. 


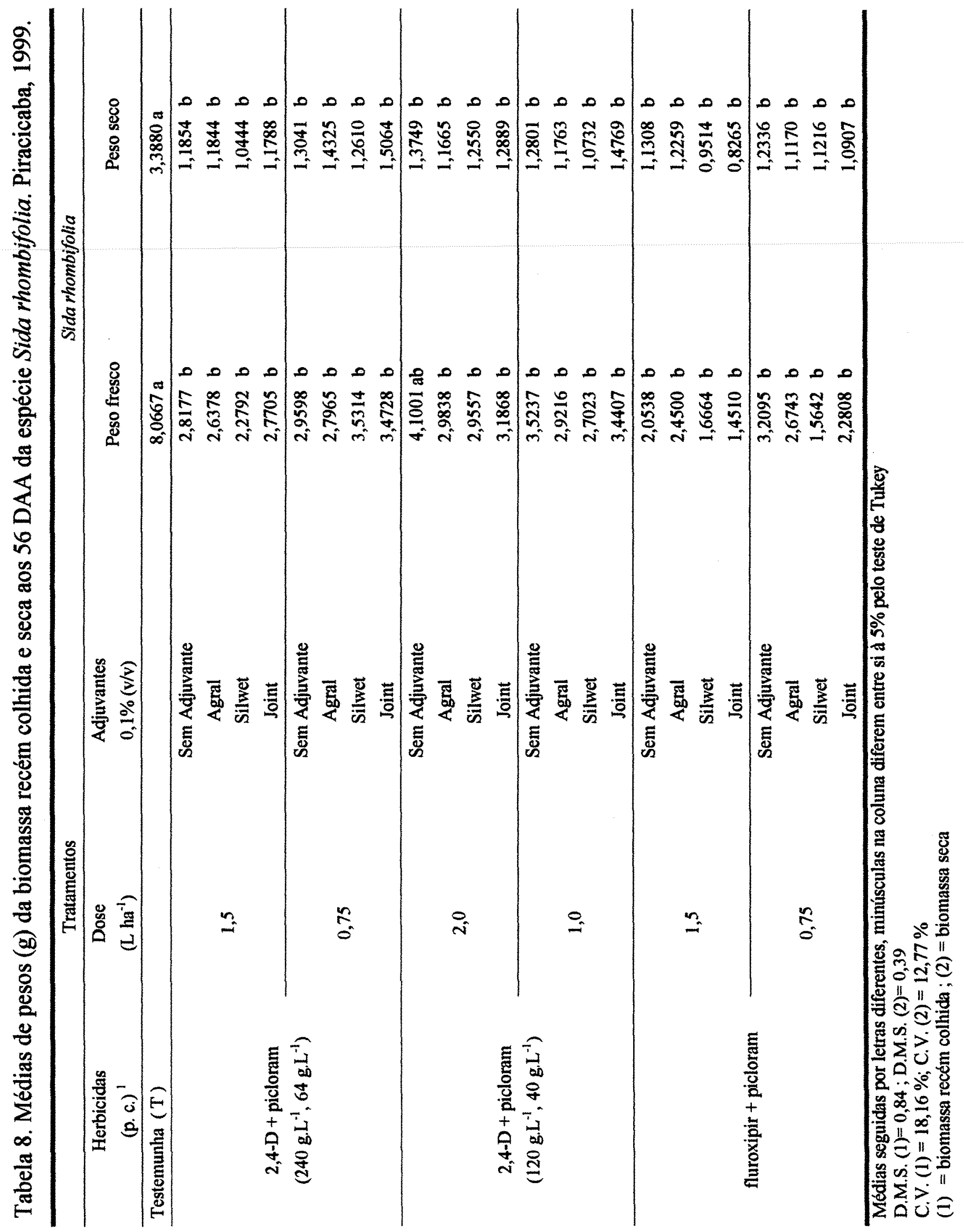


Tabela 9. Biomassa recém colhida (g) (56 DAA) da espécie Sida rhombifolia. Piracicaba, 1999.

\begin{tabular}{|c|c|c|c|c|c|c|}
\hline \multirow{2}{*}{$\begin{array}{c}\text { Herbicida } \\
\text { (p.c.) }\end{array}$} & \multirow{2}{*}{$\begin{array}{c}\text { Dose } \\
\left(\mathrm{L} \mathrm{ha}^{-1}\right)\end{array}$} & \multirow{2}{*}{$\begin{array}{c}\text { Sem } \\
\text { Adjuvante }\end{array}$} & \multicolumn{3}{|c|}{ Adjuvante } & \multirow{2}{*}{ Média } \\
\hline & & & Agral & Silwet & Joint & \\
\hline 2,4-D + picloram & 1,5 & $2,82^{*}$ & 2,64 & 2,28 & 2,77 & $2,62 a b$ \\
\hline$\left(240\right.$ g. $L^{-1}, 64$ g.L $\left.L^{-1}\right)$ & 0,75 & 2,96 & 3,80 & 3,53 & 3,47 & $3,43 \mathrm{a}$ \\
\hline 2,4-D + picloram & 2,0 & 4,10 & 2,98 & 2,96 & 3,19 & $3,29 a$ \\
\hline$\left(120 \mathrm{~g} \cdot \mathrm{L}^{-1}, 40 \mathrm{~g} \cdot \mathrm{L}^{-1}\right)$ & 1,0 & 3,52 & 2,92 & 2,70 & 3,44 & $3,14 \mathrm{a}$ \\
\hline \multirow{2}{*}{ fluroxipir + picloram } & 1,5 & 2,05 & 2,45 & 1,67 & 1,45 & $2,39 \mathrm{ab}$ \\
\hline & 0,75 & 3,21 & 2,67 & 1,56 & 2,28 & $1,89 \mathrm{~b}$ \\
\hline Média & & $3,08 \mathrm{~A}$ & $2,90 \mathrm{~A}$ & $2,40 \mathrm{~A}$ & $2,71 \mathrm{~A}$ & \\
\hline
\end{tabular}

D.M.S. = Diferença mínima significativa para comparação de (1) herbicidas e (2) adjuvantes.

D.M.S. $(1)=0,32$; D.M.S. $(2)=0,24$

C.V. $=18,83 \%$

" Dados transformados segundo $\sqrt{x+0,5}$

Médias seguidas por letras diferentes, maiúsculas na linha e minúsculas na coluna diferem entre si à $5 \%$ pelo teste de Tukey

A Tabela 10 mostra que na biomassa seca só houve diferença significativa entre fluroxipir + picloram na dose de $1,5 \mathrm{~L}$ de p.c. $\mathrm{ha}^{-1}$ e 2,4-D + picloram $\left(240\right.$ g.L $L^{-1}, 64$ g.L $\left.L^{-1}\right)$ na dose de $0,75 \mathrm{~L}$ de p.c. ha ${ }^{-1}$. Entre os adjuvantes não houve diferença significativa. 
Tabela 10. Biomassa seca (g) (56 DAA) da espécie Sida rhombifolia. Piracicaba, 1999.

\begin{tabular}{|c|c|c|c|c|c|c|}
\hline \multirow{2}{*}{$\begin{array}{c}\text { Herbicida } \\
\text { (p.c.) }\end{array}$} & \multirow{2}{*}{$\begin{array}{l}\text { Dose } \\
\left(\mathrm{L} \mathrm{ha}^{-1}\right)\end{array}$} & \multirow{2}{*}{$\begin{array}{c}\text { Sem } \\
\text { Adjuvante }\end{array}$} & \multicolumn{3}{|c|}{ Adjuvante } & \multirow{2}{*}{ Média } \\
\hline & & & Agral & Silwet & Joint & \\
\hline 2,4-D + picloram & 1,5 & $1,19^{*}$ & 1,19 & 1,04 & 1,18 & $1,15 \mathrm{ab}$ \\
\hline$\left(240\right.$ g.L $L^{-1}, 64$ g.L $\left.L^{-1}\right)$ & 0,75 & 1,30 & 1,43 & 1,26 & 1,51 & $1,37 \mathrm{a}$ \\
\hline 2,4-D + picloram & 2,0 & 1,37 & 1,17 & 1,26 & 1,29 & $1,27 \mathrm{ab}$ \\
\hline$\left(120\right.$ g.L $L^{-1}, 40$ g.L $\left.L^{-1}\right)$ & 1,0 & 1,28 & 1,18 & 1,07 & 1,48 & $1,25 \mathrm{ab}$ \\
\hline \multirow{2}{*}{ fluroxipir + picloram } & 1,5 & 1,13 & 1,23 & 0,95 & 0,83 & $1,03 \mathrm{~b}$ \\
\hline & 0,75 & 1,23 & 1,12 & 1,12 & 1,09 & $1,14 \mathrm{ab}$ \\
\hline Média & & $1,25 \mathrm{~A}$ & $1,22 \mathrm{~A}$ & $1,11 \mathrm{~A}$ & $1,22 \mathrm{~A}$ & \\
\hline
\end{tabular}

D.M.S. = Diferença mínima significativa para comparação de (1) herbicidas e (2) adjuvantes.

D.M.S.(1) $=0,15$; D.M.S. $(2)=0,11$

C.V. $=13,24 \%$

"Dados transformados segundo $\sqrt{x+0,5}$

Médias seguidas por letras diferentes, maiúsculas na linha e minúsculas na coluna diferem entre si à $5 \%$ pelo teste de Tukey

\subsubsection{Efeito de adjuvantes no controle da espécie Sida glaziovii}

Os resultados com a espécie Sida glaziovii podem ser observados na Tabela 11 onde observa-se que aos sete dias após aplicação ( 7 DAA), o tratamento que apresentou maior índice de fitotoxicidade foi com a mistura dos herbicidas fluroxipir + picloram na dose de $1,5 \mathrm{~L}$ de p.c. ha $^{-1}$ sem adjuvante, sendo que este tratamento não diferiu de todos os outros que também continham fluroxipir + picloram. Em relação aos outros tratamentos, o fluroxipir + picloram na dose de 1,5 L de p.c. ha ${ }^{-1}$ sem adjuvante só não diferiu de 2,4-D + picloram (240 g.L $\mathrm{L}^{-1}, 64$ g.. $\left.\mathrm{L}^{-1}\right)$ na dose de $1,5 \mathrm{~L}$ de p.c. ha ${ }^{-1}$ com o adjuvante Silwet e de 2,4-D + picloram (120 g. $\mathrm{L}^{-1}, 40$ g. $\left.\mathrm{L}^{-1}\right)$ na dose de 2,0 L de p.c. ha ${ }^{-1}$ também com Silwet. 
Na Tabela 5A, observa-se que a análise de variância que comparou o efeito de herbicidas e adjuvantes, mostrou não haver interação significativa entre esses dois fatores nas quatro avaliações mas, mostra que houve efeito de herbicidas e também de adjuvantes apesar de também aqui serem independentes um do outro.

Na primeira avaliação (Tabela 12), $7 \mathrm{DAA}$, na média de todos os herbicidas, a mistura fluroxipir + picloram na dose de $1,5 \mathrm{~L}$ de p.c. $\mathrm{ha}^{-1}$ diferiu de todos os outros tratamentos. Nos adjuvantes, o Silwet apresentou a melhor nota, diferindo estatisticamente do adjuvante Joint 


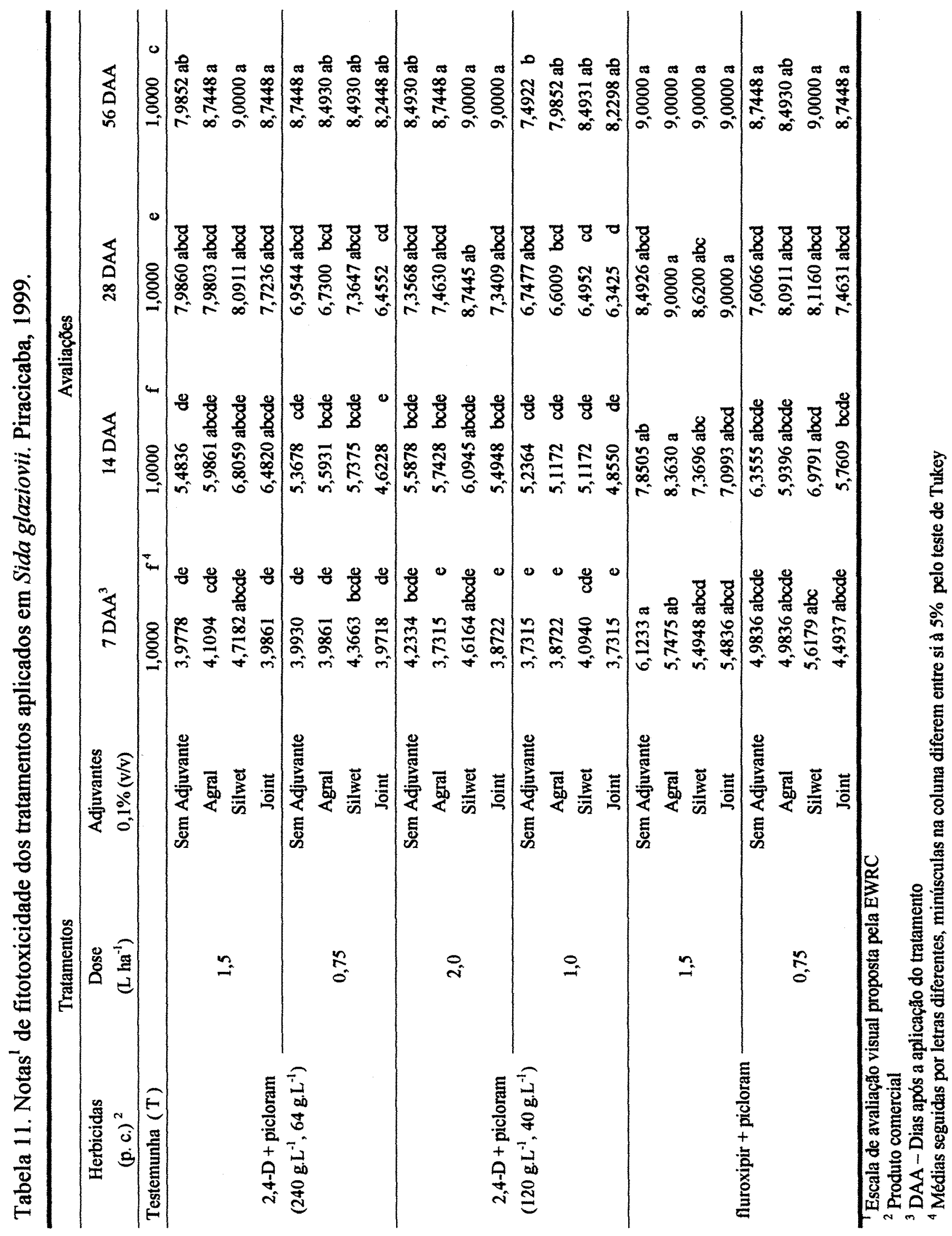


Tabela 12. Médias da primeira avaliação (7 DAA) da espécie Sida glaziovii considerando o esquema fatorial. Piracicaba, 1999.

\begin{tabular}{|c|c|c|c|c|c|c|}
\hline \multirow{2}{*}{$\begin{array}{c}\text { Herbicida } \\
\text { (p.c.) }\end{array}$} & \multirow{2}{*}{$\begin{array}{c}\text { Dose } \\
\left(\mathrm{L} \mathrm{ha}^{-1}\right)\end{array}$} & \multirow{2}{*}{$\begin{array}{c}\text { Sem } \\
\text { Adjuvante }\end{array}$} & \multicolumn{3}{|c|}{ Adjuvante } & \multirow{2}{*}{ Média } \\
\hline & & & Agral & Silwet & Joint & \\
\hline 2,4-D + picloram & 1,5 & $3,98^{*}$ & 4,11 & 4,72 & 3,99 & 4,19 c \\
\hline$\left(240\right.$ g. $.^{-1}, 64$ g.L. $\left.L^{-1}\right)$ & 0,75 & 3,99 & 3,99 & 4,37 & 3,97 & $4,08 \quad c$ \\
\hline 2,4-D + picloram & 2,0 & 4,23 & 3,73 & 4,62 & 3,87 & $4,11 \quad c$ \\
\hline$\left(120\right.$ g.L $L^{-1}, 40$ g. $\left.L^{-1}\right)$ & 1,0 & 3,37 & 3,87 & 4,09 & 3,73 & 3,86 c \\
\hline \multirow{2}{*}{ fluroxipir + picloram } & 1,5 & 6,12 & 5,75 & 5,49 & 5,48 & $5,71 \mathrm{a}$ \\
\hline & 0,75 & 4,98 & 4,98 & 5,62 & 4,49 & $5,01 \mathrm{~b}$ \\
\hline Média & & $4,48 \mathrm{AB}$ & $4,38 \mathrm{AB}$ & $4,80 \mathrm{~A}$ & $4,24 \mathrm{~B}$ & \\
\hline
\end{tabular}

D.M.S. = Diferença mínima significativa para comparação de (1) herbicidas e (2) adjuvantes.

D.M.S. $(1)=0,13 ;$ D.M.S. $(2)=0,10$

C.V. $=5,78 \%$

"Dados transformados segundo $\sqrt{x+0,5}$

Médias seguidas por letras diferentes, maiúsculas na linha e minúsculas na coluna diferem entre si à $5 \%$ pelo teste de Tukey

Na Tabela 11, 14 DAA a mistura fluroxipir + picloram na dose de $1.5 \mathrm{~L}$ de p.c. ha $^{-1}$ com o surfactante Agral apresentou maior nota de fitotoxicidade diferindo dentro dos tratamentos com fluroxipir + picloram apenas do tratamento na dose de $0,75 \mathrm{~L}$ de p.c. $\mathrm{ha}^{-1}$ com Joint. Observa-se que este tratamento não diferiu significativamente do tratamento de 2,4-D + picloram $\left(240\right.$ g.L $\mathrm{L}^{-1}, 64$ g.L $\left.\mathrm{L}^{-1}\right)$ na dose de 1,5 L de p.c. ha $^{-1}$ com os adjuvante Agral, Silwet e Joint. e do 2,4-D + picloram $\left(120 \mathrm{~g} . \mathrm{L}^{-1}, 40 \mathrm{~g} \cdot \mathrm{L}^{-1}\right)$, não diferiu apenas do tratamento em dose de $2,0 \mathrm{~L}$ de p.c. $\mathrm{ha}^{-1}$ com Silwet. Na Tabela 13 observa-se que a mistura fluroxipir + picloram na dose de $1,5 \mathrm{~L}$ de p.c. $\mathrm{ha}^{-1}$, diferiu significativamente de todos os outros. Nessa avaliação não houve diferença entre os adjuvantes, apesar do Silwet, na média, apresentar maior nota. 
Tabela 13. Médias da segunda avaliação (14 DAA) da espécie Sida glaziovii considerando o esquema fatorial. Piracicaba, 1999.

\begin{tabular}{|c|c|c|c|c|c|c|}
\hline \multirow{2}{*}{$\begin{array}{c}\text { Herbicida } \\
\text { (p.c.) }\end{array}$} & \multirow{2}{*}{$\begin{array}{c}\text { Dose } \\
\left(\mathrm{L} \mathrm{ha}^{-1}\right)\end{array}$} & \multirow{2}{*}{$\begin{array}{c}\text { Sem } \\
\text { Adjuvante }\end{array}$} & \multicolumn{3}{|c|}{ Adjuvante } & \multirow{2}{*}{ Média } \\
\hline & & & Agral & Silwet & Joint & \\
\hline 2,4-D + picloram & 1,5 & $5,48^{*}$ & 5,99 & 6,81 & 6,48 & $6,18 b c$ \\
\hline$\left(240\right.$ g.L $L^{-1}, 64$ g.L $\left.{ }^{-1}\right)$ & 0,75 & 5,37 & 5,59 & 5,74 & 4,62 & $5,32 \mathrm{~cd}$ \\
\hline 2,4-D + picloram & 2,0 & 5,59 & 5,74 & 6,09 & 5,49 & 5,73 bcd \\
\hline$\left(120\right.$ g.L $L^{-1}, 40$ g.. $\left.{ }^{-1}\right)$ & 1,0 & 5,24 & 5,12 & 5,12 & 4,86 & 5,08 \\
\hline \multirow{2}{*}{ fluroxipir + picloram } & 1,5 & 7,85 & 8,36 & 7,37 & 7,10 & $7,66 \mathrm{a}$ \\
\hline & 0,75 & 6,36 & 5,94 & 6,98 & 5,76 & $6,25 \mathrm{~b}$ \\
\hline Média & & $5,95 \mathrm{~A}$ & $6,09 \mathrm{~A}$ & $6,33 \mathrm{~A}$ & $5,69 \mathrm{~A}$ & \\
\hline
\end{tabular}

D.M.S.= Diferença mínima significativa para comparação de (1) herbicidas e (2) adjuvantes.

D.M.S. $(1)=0,18 ;$ D.M.S. $(2)=0,13$

C. V. $=6,64 \%$

Dados transformados segundo $\sqrt{x+0,5}$

Médias seguidas por letras diferentes, maúsculas na linha e minúsculas na coluna diferem entre si à $5 \%$ pelo teste de Tukey

$\mathrm{Na}$ terceira avaliação, 28 DAA os tratamentos com fluroxipir + picloram na dose de 1,5 L de p.c. ha $^{-1}$ em combinação com Agral ou com Joint apresentaram o maior índice de fitotoxicidade diferindo significativamente dos tratamentos com 2,4-D + picloram $\left(240\right.$ g.L $\mathrm{L}^{-1}, 64$ g.L $\left.\mathrm{L}^{-1}\right)$ na dose $0,75 \mathrm{~L}$ de p.c. ha ${ }^{-1}$ com Agral ou Joint e do 2,4-D + picloram (120 g. $\mathrm{L}^{-1}, 40$ g. $\left.\mathrm{L}^{-1}\right)$ na dose de 1,0 L de p.c. ha $^{-1}$ com Agral, Silwet ou Joint (Tabela 11). Na Tabela 14 observa-se que fluroxipir + picloram na dose de $1,5 \mathrm{~L}$ de p.c. $\mathrm{ha}^{-1}$ obteve melhor nota de fitotoxicidade e só não diferiu de 2,4-D + picloram (240 g.L $\mathrm{L}^{-1}, 64$ g.L $\left.\mathrm{L}^{-1}\right)$ também na dose de $1,5 \mathrm{~L}$ de p.c. $\mathrm{ha}^{-1}$. Em relação aos adjuvantes não ocorreu diferença entre os tratamentos. 
Tabela 14. Médias da terceira avaliação (28 DAA) da espécie Sida glaziovii considerando o esquema fatorial. Piracicaba, 1999.

\begin{tabular}{|c|c|c|c|c|c|c|}
\hline \multirow{2}{*}{$\begin{array}{c}\text { Herbicida } \\
\text { (p.c.) }\end{array}$} & \multirow{2}{*}{$\begin{array}{c}\text { Dose } \\
\left(\mathrm{L} \mathrm{ha}^{-1}\right)\end{array}$} & \multirow{2}{*}{$\begin{array}{c}\text { Sem } \\
\text { Adjuvante }\end{array}$} & \multicolumn{3}{|c|}{ Adjuvante } & \multirow{2}{*}{ Média } \\
\hline & & & Agral & Silwet & Joint & \\
\hline 2,4-D + picloram & 1,5 & 7,99* & 7,98 & 8,09 & 7,72 & $7,95 \mathrm{ab}$ \\
\hline$\left(240\right.$ g.L $L^{-1}, 64$ g.L $\left.L^{-1}\right)$ & 0,75 & 6,95 & 6,73 & 7,36 & 6,50 & $6,88 \mathrm{cc}$ \\
\hline 2,4-D + picloram & 2,0 & 7,36 & 7,46 & 8,74 & 7,34 & 7,72 bc \\
\hline$\left(120\right.$ g. $L^{-1}, 40$ g.L $\left.L^{-1}\right)$ & 1,0 & 6,75 & 6,60 & 6,50 & 6,34 & 6,55 \\
\hline \multirow{2}{*}{ fluroxipir + picloram } & 1,5 & 8,49 & 9,00 & 8,62 & 9,00 & $8,78 \mathrm{a}$ \\
\hline & 0,75 & 7,61 & 8,09 & 8,12 & 7,46 & $7,82 \mathrm{~b}$ \\
\hline Média & & $7,51 \mathrm{~A}$ & $7,62 \mathrm{~A}$ & $7,89 \mathrm{~A}$ & 7,37 A & \\
\hline \multicolumn{7}{|c|}{ D.M.S.= Diferença mínima significativa para comparação de (1) herbicidas e (2) adjuvantes. } \\
\hline \multicolumn{7}{|c|}{ D.M.S. $(1)=0,16 ;$ D.M.S. $(2)=0,12$} \\
\hline C.V. $=5,57 \%$ & & & & & & \\
\hline
\end{tabular}

*Dados transformados segundo $\sqrt{x+0,5}$

Médias seguidas por letras diferentes, maiúsculas na linha e minúsculas na coluna diferem entre si à $5 \%$ pelo teste de Tukey

Na última avaliação da espécie Sida glaziovii (56 DAA) observa-se na Tabela 11 que todos os tratamentos com fluroxipir + picloram na dose de 1,5 L de p.c. $\mathrm{ha}^{-1}$ receberam a maior nota de fitotoxicidade provocando a morte da parte aérea da planta daninha. Com a dose de $0,75 \mathrm{~L}$ de p.c. ha $^{-1}$, o fluroxipir + picloram com Silwet causou o mesmo efeito. Também receberam esta nota, os tratamentos com 2,4-D + picloram (240 g. $\mathrm{L}^{-1}, 64$ g. $\left.\mathrm{L}^{-1}\right)$ na dose de $1,5 \mathrm{~L}$ de p.c. $\mathrm{ha}^{-1}$ em combinação com Silwet e 2,4-D + picloram (120 g.L $\left.\mathrm{L}^{-1}, 40 \mathrm{~g} \cdot \mathrm{L}^{-1}\right)$ na dose de $2,0 \mathrm{~L}$ de p.c. ha $^{-1}$ em combinação com Silwet e Joint.

Na Tabela 15 pode-se observar que $56 \mathrm{DAA}$, fluroxipir + picloram na dose de $1,5 \mathrm{~L}$ de p.c. ha $^{-1}$ ainda apresentou a maior nota, assim como na avaliação de 28 DAA mas, não diferiu em termos estatísticos de 2,4-D + picloram ( $240 \mathrm{~g}$. $\mathrm{L}^{-1}, 64$ g. $\left.\mathrm{L}^{-1}\right)$ e 2,4-D + picloram $\left(120\right.$ g. $\mathrm{L}^{-1}, 40$ g. $\left.\mathrm{L}^{-1}\right)$ nas doses de $1,5 \mathrm{~L}$ de p.c. $\mathrm{ha}^{-1}$ e $2,0 \mathrm{~L}$ de p.c. $\mathrm{ha}^{-1}$ respectivamente, e de fluroxipir + picloram na dose de 
$0,75 \mathrm{~L}$ de p.c. $\mathrm{ha}^{-1}$. O adjuvante Silwet apresentou melhor resultado e difere do tratamento que não apresentou adjuvante.

Tabela 15. Médias da quarta avaliação (56 DAA) da espécie Sida glaziovii considerando o esquema fatorial. Piracicaba, 1999.

\begin{tabular}{|c|c|c|c|c|c|c|}
\hline \multirow{2}{*}{$\begin{array}{c}\text { Herbicida } \\
\text { (p.c.) }\end{array}$} & \multirow{2}{*}{$\begin{array}{c}\text { Dose } \\
\left(\mathrm{L} \mathrm{ha}^{-1}\right)\end{array}$} & \multirow{2}{*}{$\begin{array}{c}\text { Sem } \\
\text { Adjuvante }\end{array}$} & \multicolumn{3}{|c|}{ Adjuvante } & \multirow{2}{*}{ Média } \\
\hline & & & Agral & Silwet & Joint & \\
\hline 2,4-D + picloram & 1,5 & $7,99 *$ & 8,74 & 9,00 & 8,74 & $8,61 a b$ \\
\hline$\left(240\right.$ g.L $L^{-1}, 64$ g.L $\left.L^{-1}\right)$ & 0,75 & 8,74 & 8,49 & 8,49 & 8,24 & 8,49 bc \\
\hline 2,4-D + picloram & 2,0 & 8,49 & 8,74 & 9,00 & 9,00 & $8,81 \mathrm{ab}$ \\
\hline$\left(120\right.$ g. $L^{-1}, 40$ g. $\left.L^{-1}\right)$ & 1,0 & 7,49 & 8,74 & 8,49 & 8,23 & $8,05 \mathrm{c}$ \\
\hline \multirow{2}{*}{ fluroxipir + picloram } & 1,5 & 9,00 & 9,00 & 9,00 & 9,00 & $9,00 \mathrm{a}$ \\
\hline & 0,75 & 8,74 & 8,49 & 9,00 & 8,74 & $8,74 \mathrm{ab}$ \\
\hline Média & & $8,40 \mathrm{~B}$ & $8,57 \mathrm{AB}$ & $8,83 \mathrm{~A}$ & $8,66 \mathrm{AB}$ & \\
\hline
\end{tabular}

D.M.S. = Diferença minima significativa para comparação de (1) herbicidas e (2) adjuvantes.

D.M.S.(1) $=0,08$; D.M.S. $(2)=0,06$

C. V. $=2,63 \%$

Dados transformados segundo $\sqrt{x+0,5}$

Médias seguidas por letras diferentes, maiúsculas na linha e minúsculas na coluna diferem entre si à $5 \%$ pelo teste de Tukey

Nos resultados de biomassa na Tabela 16 pode-se observar que 0 tratamento com 2,4-D + picloram $\left(120\right.$ g.L $\left.\mathrm{L}^{-1}, 40 \mathrm{~g} . \mathrm{L}^{-1}\right)$ na dose de $2,0 \mathrm{~L}$ de p.c. $\mathrm{ha}^{-1}$ com adjuvante Silwet apresentou menor peso da biomassa recém colhida, seguida pelo tratamento de fluroxipir + picloram na dose de $1,5 \mathrm{~L}$ de p.c. $\mathrm{ha}^{-1} \mathrm{com}$ o adjuvante Joint. Nos resultados de biomassa seca observou-se os menores pesos nos mesmos tratamentos. Nas Tabelas 17 e 18 verificou-se que fluroxipir + picloram na dose de $1,5 \mathrm{~L}$ de p.c. ha $^{-1}$ diferiu estatisticamente dos herbicidas 2,4-D + picloram (240 g. $\mathrm{L}^{-1}, 64$ g. $\left.\mathrm{L}^{-1}\right)$ na dose de $0,75 \mathrm{~L}$ de p.c. $\mathrm{ha}^{-1}$ e 2,4-D + picloram $\left(120\right.$ g.L $\mathrm{L}^{-1}, 40$ g. $\left.\mathrm{L}^{-1}\right)$ na dose de $1,0 \mathrm{~L}$ de p.c. ha ${ }^{-1}$ apresentando menor 
peso tanto na biomassa recém colhida como na biomassa seca. Entre os adjuvantes não houve diferença alguma apesar dos pesos dos tratamentos com Silwet apresentarem sempre menores valores. 


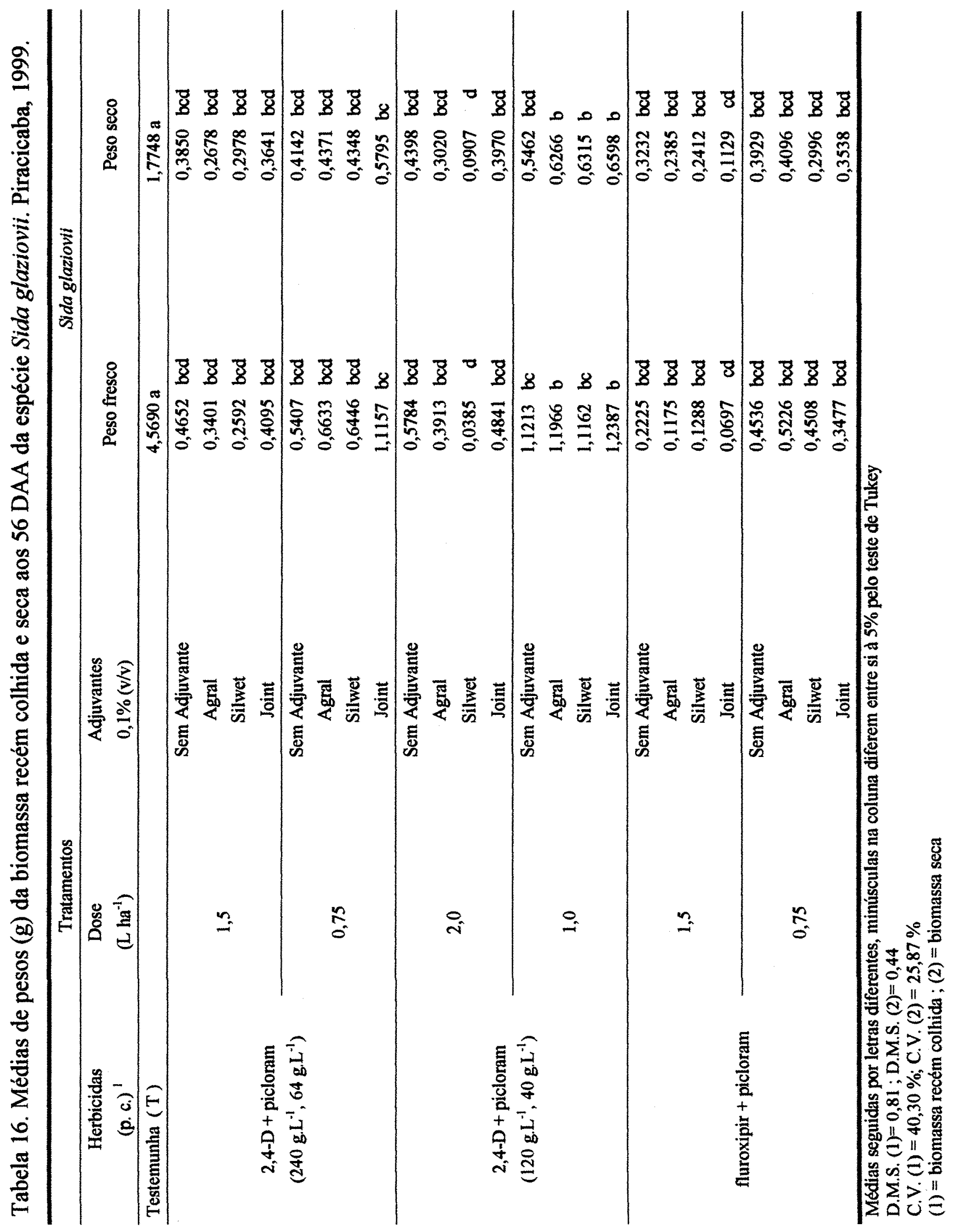


Tabela 17. Avaliação da biomassa recém colhida (g) (56 DAA) da espécie Sida glaziovii. Piracicaba, 1999.

\begin{tabular}{|c|c|c|c|c|c|c|}
\hline \multirow{2}{*}{$\begin{array}{l}\text { Herbicida } \\
\text { (p.c.) }\end{array}$} & \multirow{2}{*}{$\begin{array}{l}\text { Dose } \\
\left(\mathrm{L} \mathrm{ha}^{-1}\right)\end{array}$} & \multirow{2}{*}{$\begin{array}{c}\text { Sem } \\
\text { Adjuvante }\end{array}$} & \multicolumn{3}{|c|}{ Adjuvante } & \multirow{2}{*}{ Média } \\
\hline & & & Agral & Silwet & Joint & \\
\hline 2,4-D + picloram & 1,5 & $0,47^{*}$ & 0,34 & 0,26 & 0,41 & $0,36 b c$ \\
\hline$\left(240\right.$ g.L $L^{-1}, 64$ g.L $\left.L^{-1}\right)$ & 0,75 & 0,54 & 0,66 & 0,63 & 1,12 & $0,72 \mathrm{ab}$ \\
\hline \multirow{2}{*}{$\begin{array}{c}\text { 2,4-D + picloram } \\
\left(120 \text { g.L } L^{-1}, 40 \text { g.L } L^{-1}\right)\end{array}$} & 2,0 & 0,58 & 0,39 & 0,04 & 0,48 & 0,32 bc \\
\hline & 1,0 & 1,12 & 1,20 & 1,12 & 1,24 & $1,17 \mathrm{a}$ \\
\hline \multirow{2}{*}{ fluroxipir + picloram } & 1,5 & 0,22 & 0,18 & 0,13 & 0,07 & $0,13 \quad c$ \\
\hline & 0,75 & 0,45 & 0,52 & 0,45 & 0,35 & 0,44 bc \\
\hline Média & & $0,53 \mathrm{~A}$ & $0,49 \mathrm{~A}$ & $0,36 \mathrm{~A}$ & $0,53 \mathrm{~A}$ & \\
\hline
\end{tabular}

D.M.S.= Diferença mínima significativa para comparação de (1) herbicidas e (2) adjuvantes.

D.M.S. $(1)=0,31$; D.M.S. $(2)=0,23$

C.V. $=43,71 \%$

"Dados transformados segundo $\sqrt{x+0,5}$

Médias seguidas por letras diferentes, maiúsculas na linha e minúsculas na coluna diferem entre si à $5 \%$ pelo teste de Tukey

Tabela 18. Avaliação da biomassa seca (g) (56 DAA) da espécie Sida glaziovii. Piracicaba, 1999.

\begin{tabular}{|c|c|c|c|c|c|c|}
\hline \multirow{2}{*}{$\begin{array}{l}\text { Herbicida } \\
\text { (p.c.) }\end{array}$} & \multirow{2}{*}{$\begin{array}{l}\text { Dose } \\
\left(\mathrm{L} \mathrm{ha}{ }^{-1}\right)\end{array}$} & \multirow{2}{*}{$\begin{array}{c}\text { Sem } \\
\text { Adjuvante }\end{array}$} & \multicolumn{3}{|c|}{ Adjuvante } & \multirow{2}{*}{ Média } \\
\hline & & & Agral & Silwet & Joint & \\
\hline 2,4-D + picloram & 1,5 & $0,39 *$ & 0,27 & 0,30 & 0,36 & 0,33 bc \\
\hline$\left(240\right.$ g.L $L^{-1}, 64$ g.L $\left.L^{-1}\right)$ & 0,75 & 0,41 & 0,44 & 0,43 & 0,60 & $0,46 \mathrm{ab}$ \\
\hline \multirow{2}{*}{$\begin{array}{c}\text { 2,4-D + picloram } \\
\left(120 \text { g. } \mathrm{L}^{-1}, 40 \mathrm{~g} \cdot \mathrm{L}^{-1}\right)\end{array}$} & 2,0 & 0,44 & 0,30 & 0,09 & 0,40 & $0,29 \mathrm{bc}$ \\
\hline & 1,0 & 0,55 & 0,63 & 0,63 & 0,70 & $0,62 \mathrm{a}$ \\
\hline \multirow{2}{*}{ fluroxipir + picloram } & 1,5 & 0,32 & 0,24 & 0,24 & 0,11 & 0,22 \\
\hline & 0,75 & 0,39 & 0,41 & 0,30 & 0,35 & $0,36 \mathrm{bc}$ \\
\hline Média & & $0,41 \mathrm{~A}$ & $0,37 \mathrm{~A}$ & $0,31 \mathrm{~A}$ & $0,39 \mathrm{~A}$ & \\
\hline
\end{tabular}

D.M.S. = Diferença mínima significativa para comparação de (1) herbicidas e (2) adjuvantes.

D.M.S. $(1)=0,17$; D.M.S. $(2)=0,13$

C.V. $=27,53 \%$

Dados transformados segundo $\sqrt{x+0,5}$

Médias seguidas por letras diferentes, maiúsculas na linha e minúsculas na coluna diferem entre si à $5 \%$ pelo teste de Tukey 


\subsubsection{Efeito de adjuvantes no controle da espécie Sida cordifolia}

A planta daninha da espécie Sida cordifolia foi a que apresentou maior sensibilidade aos tratamentos utilizados. Nas avaliações dessa espécie não observou-se tantas diferenças entre os herbicidas aplicados. Os resultados da Tabela 19, mostram que desde os sete dias após a aplicação (7 DAA) a espécie Sida cordifolia apresentou notas de fitotoxicidade mais altas do que as outras duas espécies analisadas. Os tratamentos que causaram maiores notas de fitotoxicidade foram os que continham fluroxipir + picloram na dose de $1,5 \mathrm{~L}$ de p.c. ha $^{-1}$ sem adjuvante ou com Silwet e estes só diferiram significativamente do tratamento com 2,4-D + picloram $\left(120\right.$ g. $\mathrm{L}^{-1}, 40$ g. $\left.\mathrm{L}^{-1}\right)$ a $1,0 \mathrm{~L}$ de p.c. $\mathrm{ha}^{-1}$ com o adjuvante Joint. Aos 14 DAA, o tratamento 2,4-D + picloram (120 g.L $\mathrm{L}^{-1}, 40$ g. $\left.\mathrm{L}^{-1}\right)$ a $1,0 \mathrm{~L}$ de p.c. $\mathrm{ha}^{-1}$ continuou sendo o pior tratamento diferindo estatisticamente agora do tratamento com fluroxipir + picloram na dose de $1,5 \mathrm{~L}$ de p.c. $\mathrm{ha}^{-1} \mathrm{com} \mathrm{o}$ adjuvante Joint que apresentou a maior nota de fitotoxicidade. Aos $28 \mathrm{DAA}$, não houve diferença estatística entre os tratamentos, todavia com 2,4-D + picloram $\left(120\right.$ g. $\mathrm{L}^{-1}, 40$ g.L $\left.\mathrm{L}^{-1}\right)$ a 2,0 L de p.c. $\mathrm{ha}^{-1}$ sem adjuvante ou com Joint e fluroxipir + picloram na dose de $1,5 \mathrm{~L}$ de p.c. $\mathrm{ha}^{-1}$ sem adjuvante ou com Joint, apresentam as notas máximas de fitotoxicidade que está relacionada com a morte da parte aérea da planta.

Os resultados aos 56 DAA mostram que apenas os tratamentos com 2,4-D + picloram (120 g. $\mathrm{L}^{-1}, 40$ g. $\left.\mathrm{L}^{-1}\right)$ a $1,0 \mathrm{~L}$ de p.c. ha $^{-1}$ sem adjuvante ou com Joint não receberam a nota máxima de fitotoxicidade sendo que apenas este último diferiu dos demais (Tabela 19). 


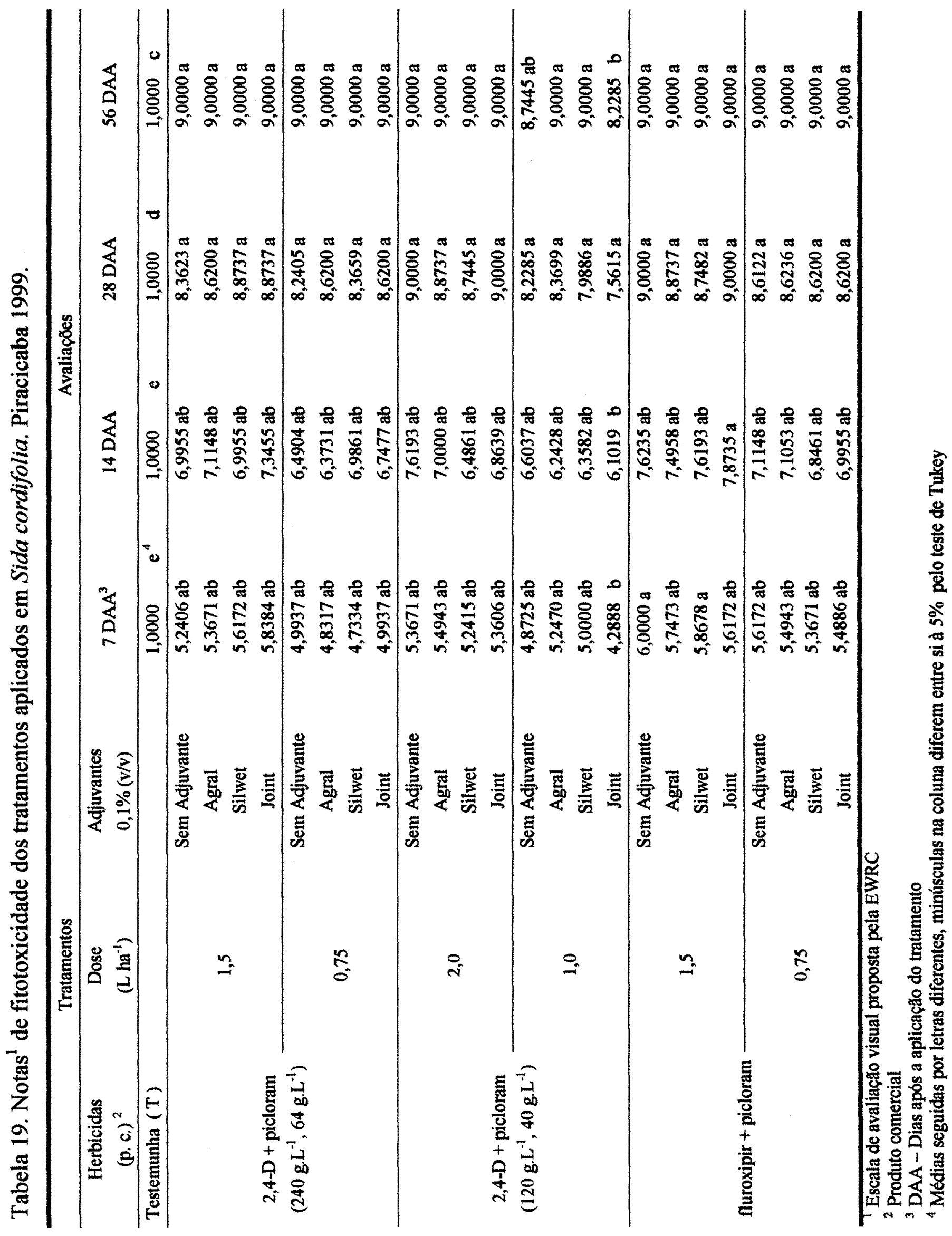


Na tabela $6 \mathrm{~A}$, observou-se que a análise de variância que comparou 0 efeito de herbicidas e adjuvantes, mostrou não haver interação significativa entre esses dois fatores nas quatro avaliações mas, mostra que houve efeito de herbicidas e também de adjuvantes.

Nos dados das Tabelas 20 e 21 , pode-se observar que, em média fluroxipir + picloram na dose de $1,5 \mathrm{~L}$ de p.c. ha $^{-1}$ só diferiu significativamente de 2,4-D + picloram (240 g.L $\mathrm{L}^{-1}, 64$ g.L $\left.\mathrm{L}^{-1}\right)$ a $0,75 \mathrm{~L}$ de p.c. $\mathrm{ha}^{-1}$ e 2,4-D + picloram $\left(120\right.$ g. $\left.\mathrm{L}^{-1}, 40 \mathrm{~g} . \mathrm{L}^{-1}\right)$ a $1,0 \mathrm{~L}$ de p.c. ha ${ }^{-1}$, enquanto que entre os adjuvantes não houve diferença.

Tabela 20. Médias da primeira avaliação (7 DAA) da espécie Sida cordifolia considerando o esquema fatorial. Piracicaba, 1999.

\begin{tabular}{cccccccc}
\hline Herbicida & Dose & Sem & \multicolumn{4}{c}{ Adjuvante } & \multirow{2}{*}{ (p.c. $)$} \\
\cline { 4 - 6 }$\left(\mathrm{L} \mathrm{ha}^{-1}\right)$ & Adjuvante & Agral & Silwet & Joint & \\
\hline 2,4-D + picloram & 1,5 & $5,24^{*}$ & 5,37 & 5,62 & 5,84 & $5,51 \mathrm{a}$ \\
$\left(240 \mathrm{~g}^{-1} \mathrm{~L}^{-1}, 64 \mathrm{~g} \cdot \mathrm{L}^{-1}\right)$ & 0,75 & 4,99 & 4,83 & 4,73 & 4,99 & $4,89 \mathrm{bc}$ \\
\hline $2,4-\mathrm{D}+$ picloram & 2,0 & 5,37 & 5,49 & 5,24 & 5,36 & $5,37 \mathrm{abc}$ \\
$\left(120 \mathrm{~g} \cdot \mathrm{L}^{-1}, 40 \mathrm{~g} \cdot \mathrm{L}^{-1}\right)$ & 1,0 & 4,87 & 5,25 & 5,00 & 4,29 & $4,85 \quad \mathrm{c}$ \\
\hline \multirow{2}{*}{ fluroxipir + picloram } & 1,5 & 6,00 & 5,75 & 5,87 & 5,62 & $5,81 \mathrm{a}$ \\
& 0,75 & 5,62 & 5,49 & 5,37 & 5,49 & $5,49 \mathrm{ab}$ \\
\hline Média & & $5,34 \mathrm{~A}$ & $5,36 \mathrm{~A}$ & $5,30 \mathrm{~A}$ & $5,25 \mathrm{~A}$ & \\
\hline
\end{tabular}

D.M.S. = Diferença mínima significativa para comparação de (1) herbicidas e (2) adjuvantes.

D.M.S.(1) $=0,14$; D.M.S. $(2)=0,10$

C.V. $=5,70 \%$

Dados transformados segundo $\sqrt{x+0,5}$

Médias seguidas por letras diferentes, maiúsculas na linha e minúsculas na coluna diferem entre si à 5\% pelo teste de Tukey 
Tabela 21. Médias da segunda avaliação (14 DAA) da espécie Sida cordifolia considerando o esquema fatorial. Piracicaba, 1999.

\begin{tabular}{cccccccc}
\hline Herbicida & Dose & Sem & \multicolumn{4}{c}{ Adjuvante } & \multirow{2}{*}{ (p.c. $)$} \\
\cline { 4 - 6 } & $\left(\mathrm{L} \mathrm{ha}^{-1}\right)$ & Adjuvante & Agral & Silwet & Joint & \\
\hline 2,4-D + picloram & 1,5 & $6,99 *$ & 7,11 & 6,99 & 7,35 & $7,11 \mathrm{ab}$ \\
$\left(240 \mathrm{~g} \cdot \mathrm{L}^{-1}, 64 \mathrm{~g} . \mathrm{L}^{-1}\right)$ & 0,75 & 6,49 & 6,37 & 6,99 & 6,75 & $6,65 \mathrm{bc}$ \\
\hline $2,4-\mathrm{D}+$ picloram & 2,0 & 7,62 & 7,00 & 6,49 & 6,86 & $6,99 \mathrm{ab}$ \\
$\left(120 \mathrm{~g} . \mathrm{L}^{-1}, 40 \mathrm{~g} . \mathrm{L}^{-1}\right)$ & 1,0 & 6,60 & 6,24 & 6,36 & 6,10 & $6,33 \quad \mathrm{c}$ \\
\hline \multirow{2}{*}{ fluroxipir + picloram } & 1,5 & 7,62 & 7,50 & 7,62 & 7,87 & $7,65 \mathrm{a}$ \\
& 0,75 & 7,11 & 7,11 & 6,85 & 6,99 & $7,02 \mathrm{ab}$ \\
\hline Média & & $7,07 \mathrm{~A}$ & $6,88 \mathrm{~A}$ & $6,88 \mathrm{~A}$ & $6,98 \mathrm{~A}$ & \\
\hline
\end{tabular}

D.M.S.= Diferença mínima significativa para comparação de (1) herbicidas e (2) adjuvantes.

D.M.S. $(1)=0,12$; D.M.S. $(2)=0,09$

C.V. $=4,55 \%$

Dados transformados segundo $\sqrt{x+0,5}$

Médias seguidas por letras diferentes, maińsculas na linha e minúsculas na coluna diferem entre si à $5 \%$ pelo teste de Tukey

Os resultados da Tabela 22 mostram que apenas 2,4-D + picloram (120 g. $\mathrm{L}^{-1}, 40$ g. $\left.\mathrm{L}^{-1}\right)$ a $1,0 \mathrm{~L}$ de p.c. $\mathrm{ha}^{-1}$, diferiu da maior nota dada ao fluroxipir + picloram na dose de $1,5 \mathrm{~L}$ de p.c. ha $^{-1}$ sendo que na Tabela 23 aos $56 \mathrm{DAA}$, todos os resultados se igualaram estatisticamente. No que diz respeito aos tratamentos com adjuvantes, a avaliação com Sida cordifolia não apresentou nenhuma diferença significativa entre os tratamentos em nenhum momento das avaliações.

Da mesma forma os tratamentos com biomassa recém colhida e biomassa seca diferiram da testemunha e apresentaram diferença entre o tratamento com 2,4-D + picloram $\left(120\right.$ g. $\mathrm{L}^{-1}, 40$ g. $\left.\mathrm{L}^{-1}\right)$ na dose de $1,0 \mathrm{~L}$ de p.c. ha ${ }^{-1}$ que apresentou o maior peso e 2,4-D + picloram $\left(240\right.$ g.L $\mathrm{L}^{-1}, 64$ g.L $\left.\mathrm{L}^{-1}\right)$ na dose de $1,5 \mathrm{~L}$ de p.c. $\mathrm{ha}^{-1}$ com Joint e 2,4-D + picloram (120 g.L $\mathrm{L}^{-1}, 40$ g.L $\left.\mathrm{L}^{-1}\right)$ na dose de $2,0 \mathrm{~L}$ de p.c. ha ${ }^{-1}$ sem adjuvante ou com Silwet que apresentaram os menores pesos na biomassa 
recém colhida (Tabela 24) mas na média não mostram diferença significativa entre os tratamentos (Tabela 25 e 26).

Tabela 22. Médias da terceira avaliação (28 DAA) da espécie Sida cordifolia considerando o esquema fatorial. Piracicaba, 1999.

\begin{tabular}{|c|c|c|c|c|c|c|}
\hline \multirow{2}{*}{$\begin{array}{c}\text { Herbicida } \\
\text { (p.c.) }\end{array}$} & \multirow{2}{*}{$\begin{array}{l}\text { Dose } \\
\left(\mathrm{L} \mathrm{ha}^{-1}\right)\end{array}$} & \multirow{2}{*}{$\begin{array}{c}\text { Sem } \\
\text { Adjuvante }\end{array}$} & \multicolumn{3}{|c|}{ Adjuvante } & \multirow{2}{*}{ Média } \\
\hline & & & Agral & Silwet & Joint & \\
\hline 2,4-D + picloram & 1,5 & $8,36^{*}$ & 8,62 & 8,87 & 8,87 & $8,68 \mathrm{a}$ \\
\hline$\left(240\right.$ g.L $L^{-1}, 64$ g.L $\left.L^{-1}\right)$ & 0,75 & 8,24 & 8,62 & 8,37 & 8,62 & $8,46 \mathrm{ab}$ \\
\hline 2,4-D + picloram & 2,0 & 9,00 & 8,87 & 8,74 & 9,00 & $8,90 \mathrm{a}$ \\
\hline$\left(120\right.$ g.L $\left.\mathrm{L}^{-1}, 40 \mathrm{~g} . \mathrm{L}^{-1}\right)$ & 1,0 & 8,23 & 8,37 & 7,99 & 7,56 & $8,03 \mathrm{~b}$ \\
\hline \multirow{2}{*}{ fluroxipir + picloram } & 1,5 & 9,00 & 8,87 & 8,75 & 9,00 & $8,91 \mathrm{a}$ \\
\hline & 0,75 & 8,61 & 8,62 & 8,62 & 8,62 & $8,62 \mathrm{ab}$ \\
\hline Média & & $8,57 \mathrm{~A}$ & $8,66 \mathrm{~A}$ & $8,55 \mathrm{~A}$ & $8,61 \mathrm{~A}$ & \\
\hline
\end{tabular}

D.M.S. = Diferença mínima significativa para comparação de (1) herbicidas e (2) adjuvantes.

D.M.S.(1) $=0,10$; D.M.S. $(2)=0,08$

C.V. $=3,37 \%$

Dados transformados segundo $\sqrt{x+0,5}$

Médias seguidas por letras diferentes, maińsculas na linha e minúsculas na coluna diferem entre si à $5 \%$ pelo teste de Tukey 
Tabela 23. Médias da quarta avaliação (56 DAA) da espécie Sida cordifolia considerando o esquema fatorial. Piracicaba, 1999.

\begin{tabular}{|c|c|c|c|c|c|c|}
\hline \multirow{2}{*}{$\begin{array}{l}\text { Herbicida } \\
\text { (p.c.) }\end{array}$} & \multirow{2}{*}{$\begin{array}{c}\text { Dose } \\
\left(\mathrm{L} \mathrm{ha}^{-1}\right)\end{array}$} & \multirow{2}{*}{$\begin{array}{c}\text { Sem } \\
\text { Adjuvante }\end{array}$} & \multicolumn{3}{|c|}{ Adjuvante } & \multirow{2}{*}{ Média } \\
\hline & & & Agral & Silwet & Joint & \\
\hline 2,4-D + picloram & 1,5 & $9,00^{*}$ & 9,00 & 9,00 & 9,00 & $9,00 \mathrm{a}$ \\
\hline$\left(240\right.$ g.L $L^{-1}, 64$ g.L $\left.L^{-1}\right)$ & 0,75 & 9,00 & 9,00 & 9,00 & 9,00 & $9,00 \mathrm{a}$ \\
\hline \multirow{2}{*}{$\begin{array}{c}2,4-\mathrm{D}+\text { picloram } \\
\left(120 \mathrm{~g} . \mathrm{L}^{-1}, 40 \mathrm{~g} . \mathrm{L}^{-1}\right)\end{array}$} & 2,0 & 9,00 & 9,00 & 9,00 & 9,00 & $9,00 \mathrm{a}$ \\
\hline & 1,0 & 9,00 & 8,74 & 9,00 & 9,00 & $8,94 \mathrm{a}$ \\
\hline \multirow{2}{*}{ fluroxipir + picloram } & 1,5 & 8,74 & 9,00 & 9,00 & 9,00 & $8,94 \mathrm{a}$ \\
\hline & 0,75 & 9,00 & 9,00 & 9,00 & 9,00 & $9,00 \mathrm{a}$ \\
\hline Média & & $8,96 \mathrm{~A}$ & $8,96 \mathrm{~A}$ & $9,00 \mathrm{~A}$ & $9,00 \mathrm{~A}$ & \\
\hline
\end{tabular}

D.M.S. = Diferença mínima significativa para comparação de (1) herbicidas e (2) adjuvantes.

D.M.S. $(1)=0,03$; D.MS. $(2)=0,02$

C.V. $=0,79 \%$

Dados transformados segundo $\sqrt{x+0,5}$

Médias seguidas por letras diferentes, maiúsculas na linha e minúsculas na coluna diferem entre si à $5 \%$ pelo teste de Tukey 


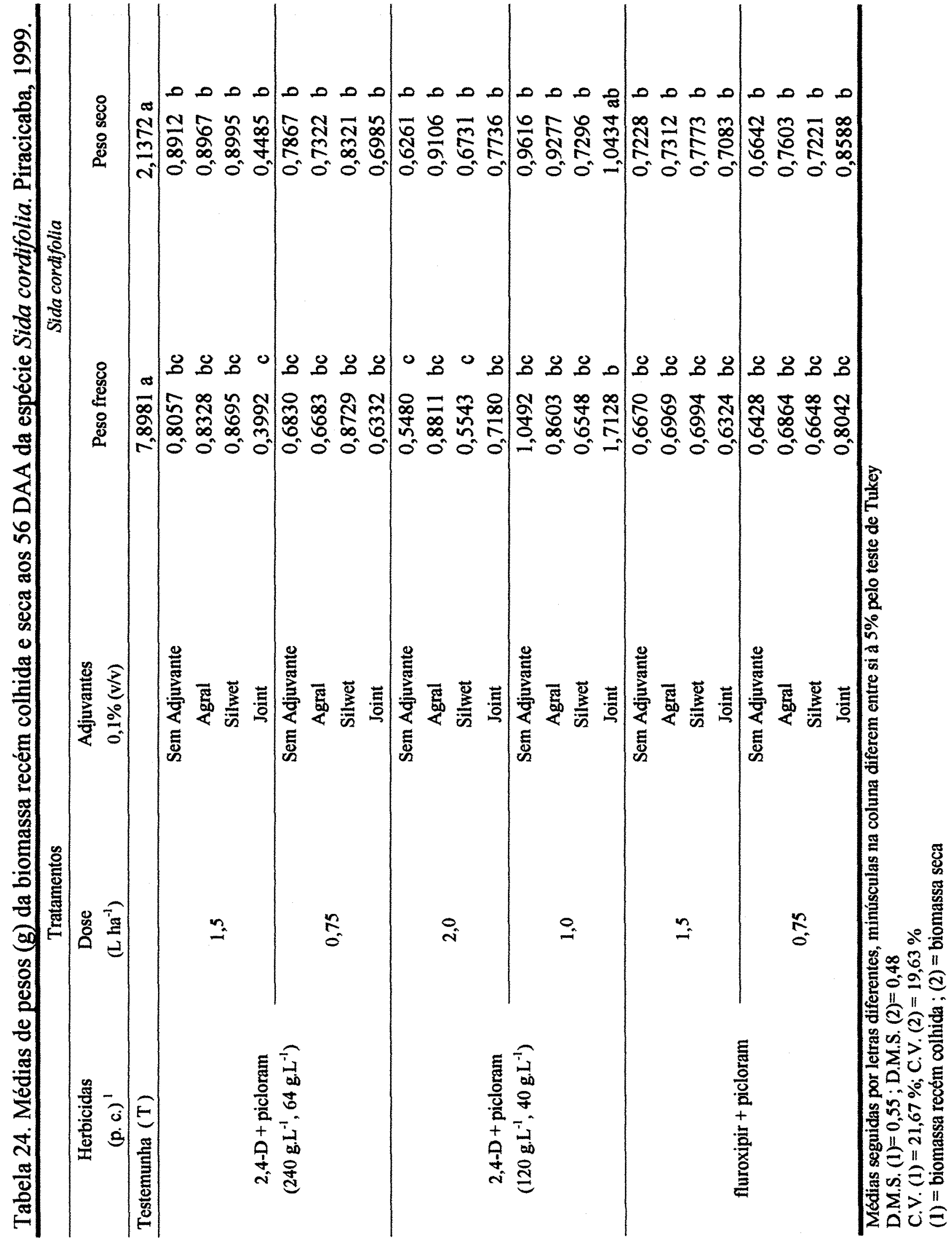


Tabela 25. Avaliação biomassa recém colhida (g) (56 DAA) da espécie Sida cordifolia. Piracicaba, 1999.

\begin{tabular}{|c|c|c|c|c|c|c|}
\hline \multirow{2}{*}{$\begin{array}{c}\text { Herbicida } \\
\text { (p.c.) }\end{array}$} & \multirow{2}{*}{$\begin{array}{c}\text { Dose } \\
\left(\mathrm{L} \mathrm{ha}^{-1}\right)\end{array}$} & \multirow{2}{*}{$\begin{array}{c}\text { Sem } \\
\text { Adjuvante }\end{array}$} & \multicolumn{3}{|c|}{ Adjuvante } & \multirow{2}{*}{ Média } \\
\hline & & & Agral & Silwet & Joint & \\
\hline 2,4-D + picloram & 1,5 & $0,81^{*}$ & 0,83 & 0,87 & 0,40 & $0,71 \mathrm{a}$ \\
\hline$\left(240\right.$ g. $L^{-1}, 64$ g. $\left.L^{-1}\right)$ & 0,75 & 0,68 & 0,67 & 0,87 & 0,63 & $0,71 \mathrm{a}$ \\
\hline $2,4-\mathrm{D}+$ picloram & 2,0 & 0,55 & 0,88 & 0,55 & 0,72 & $0,69 \mathrm{a}$ \\
\hline$\left(120\right.$ g. $\left.\mathrm{L}^{-1}, 40 \mathrm{~g} . \mathrm{L}^{-1}\right)$ & 1,0 & 1,05 & 0,86 & 0,65 & 1,71 & $1,04 \mathrm{a}$ \\
\hline \multirow{2}{*}{ fluroxipir + picloram } & 1,5 & 0,67 & 0,70 & 0,70 & 0,63 & $0,67 a$ \\
\hline & 0,75 & 0,64 & 0,69 & 0,67 & 0,80 & $0,70 \mathrm{a}$ \\
\hline Média & & $0,72 \mathrm{~A}$ & $0,77 \mathrm{~A}$ & $0,71 \mathrm{~A}$ & $0,77 \mathrm{~A}$ & \\
\hline
\end{tabular}

D.M.S. = Diferença mínima significativa para comparação de (1) herbicidas e (2) adjuvantes.

D.M.S.(1) $=0,20$; D.M.S. $(2)=0,15$

C.V. $=22,53 \%$

- Dados transformados segundo $\sqrt{x+0,5}$

Médias seguidas por letras diferentes, maiúsculas na linha e minúsculas na coluna diferem entre si à $5 \%$ pelo teste de Tukey

Tabela 26. Avaliação biomassa seca (g) (56 DAA) da espécie Sida cordifolia. Piracicaba, 1999.

\begin{tabular}{|c|c|c|c|c|c|c|}
\hline \multirow{2}{*}{$\begin{array}{c}\text { Herbicida } \\
\text { (p.c.) }\end{array}$} & \multirow{2}{*}{$\begin{array}{c}\text { Dose } \\
\left(\mathrm{L} \mathrm{ha}^{-1}\right)\end{array}$} & \multirow{2}{*}{$\begin{array}{c}\text { Sem } \\
\text { Adjuvante }\end{array}$} & \multicolumn{3}{|c|}{ Adjuvante } & \multirow{2}{*}{ Média } \\
\hline & & & Agral & Silwet & Joint & \\
\hline 2,4-D + picloram & 1,5 & $0,89 *$ & 0,90 & 0,90 & 0,45 & $0,77 \mathrm{a}$ \\
\hline$\left(240\right.$ g.L ${ }^{-1}, 64$ g.L $\left.L^{-1}\right)$ & 0,75 & 0,79 & 0,73 & 0,83 & 0,70 & $0,76 \mathrm{a}$ \\
\hline 2,4-D + picloram & 2,0 & 0,63 & 0,91 & 0,67 & 0,77 & $0,74 \mathrm{a}$ \\
\hline$\left(120\right.$ g.L $L^{-1}, 40$ g. $\left.L^{-1}\right)$ & 1,0 & 0,96 & 0,93 & 0,73 & 1,04 & $0,91 \mathrm{a}$ \\
\hline \multirow{2}{*}{ fluroxipir + picloram } & 1,5 & 0,72 & 0,73 & 0,78 & 0,71 & $0,73 \mathrm{a}$ \\
\hline & 0,75 & 0,64 & 0,76 & 0,72 & 0,86 & $0,75 \mathrm{a}$ \\
\hline Média & & $0,77 \mathrm{~A}$ & $0,82 \mathrm{~A}$ & $0,77 \mathrm{~A}$ & $0,74 \mathrm{~A}$ & \\
\hline
\end{tabular}

D.M.S. = Diferença mínima significativa para comparação de (1) herbicidas e (2) adjuvantes.

D.M.S.(1) $=0,15$; D.M.S. $(2)=0,11$

C.V. $=16,46 \%$

Dados transformados segundo $\sqrt{x+0,5}$

Médias seguidas por letras diferentes, maiúsculas na linha e minúsculas na coluna diferem entre si à $5 \%$ pelo teste de Tukey 
Ao final dos experimentos, aos $56 \mathrm{DAA}$, observou-se que entre as três espécies de guanxuma a que se mostrou mais sensível aos tratamentos foi a espécie Sida cordifolia apresentando morte total da parte aérea em praticamente $100 \%$ das plantas tratadas. Entre as espécies Sida rhombifolia e Sida glaziovii os dados dos experimentos sugerem que na aplicação dos herbicidas para controle dessas espécies, em diversos momentos das avaliações, obteve-se uma melhor nota de fitotoxicidade com fluroxipir + picloram, que na dose de $1,5 \mathrm{~L}$ de p.c. $\mathrm{ha}^{-1}$, causou morte total da parte aérea da planta de Sida glaziovii e causou as maiores fitotoxicidades na espécie Sida rhombifolia.

Dutra \& Melhorança (1997) apresentaram resultado de controle da espécie Sida rhombifolia de 100\%, aos 90 dias com a aplicação de 2,4-D + picloram (240 g.L $\mathrm{L}^{-1}, 64$ g. $\left.\mathrm{L}^{-1}\right)$ a 4,0 L de p.c. ha $^{-1}$ e também com o 2,4-D + picloram (120 g.L $\mathrm{L}^{-1}, 40$ g.L $\left.\mathrm{L}^{-1}\right)$ a $2,0 \mathrm{~L}$ de p.c. $\mathrm{ha}^{-1}$ em combinação com o surfactante Agral 0,3\% v/v.

Em trabalho com o herbicida fluroxipir + picloram, Constantin \& Contiero (1997) obtiveram um controle mínimo de $85 \%$ na dose de $1,5 \mathrm{~L}$ de p.c. $\mathrm{ha}^{-1}$, da espécie Eupatorium squalidum, igualando-se ao 2,4-D + picloram (240 g. $L^{-1}, 64$ g. $\left.L^{-1}\right)$ a $5,0 \mathrm{~L}$ de p.c. $\mathrm{ha}^{-1}$ em combinação com o surfactante Agral a $0,1 \%$ v/v. Com essa mesma espécie de planta daninha, Dutra \& Marchi (1997) obtiveram um ótimo controle (91\%) com fluroxipir + picloram na dose de $3,0 \mathrm{~L}$ de p.c. ha ${ }^{-1}$, sendo estatisticamente superior ao 2,4-D + picloram (240 g.L $\mathrm{L}^{-1}, 64$ g. $\left.\mathrm{L}^{-1}\right)$ a $4,0 \mathrm{~L}$ de p.c. $\mathrm{ha}^{-1}$ com apenas $55 \%$ de controle aos $97 \mathrm{DAA}$.

Victória Filho (1997a e 1997b) também obteve controle satisfatório da planta daninha Vernonia polyanthes com fluroxipir + picloram na dose de $3,0 \mathrm{~L}$ de p.c. ha ${ }^{-1}$ em comparação com 2,4-D + picloram $\left(240\right.$ g. $\mathrm{L}^{-1}, 64$ g. $\left.\mathrm{L}^{-1}\right)$ a $6,0 \mathrm{~L}$ de p.c. ha $^{-1}$ e com a planta daninha Sida cordifolia obteve controle com 2,4-D + 
picloram $\left(120\right.$ g.L $\mathrm{L}^{-1}, 40$ g.L $\left.\mathrm{L}^{-1}\right)$ com doses a partir de $2,0 \mathrm{~L}$ de p.c. ha ${ }^{-1}$, e de 2,4-D + picloram $\left(240\right.$ g.L $\mathrm{L}^{-1}, 64$ g. $\left.\mathrm{L}^{-1}\right) \mathrm{com}$ dose de $2,0 \mathrm{~L}$ de p.c. ha ${ }^{-1}$ em combinação com o surfactante Agral a $0,3 \%$ v/v.

Em relação aos adjuvantes no atual trabalho, obteve-se melhores eficácias nos tratamentos com o adjuvante Silwet. Inúmeros trabalhos demonstram os importantes diferenciais desse surfactante organosiliconado aumentando e melhorando a eficácia de diversos herbicidas, inclusive o herbicida fluroxipir, em relação à surfactantes convencionais (Knoche, 1994). Características como diminuição da tensão superficial da solução, uniformidade de espalhamento da calda e habilidade de penetração estomatal são amplamente relatadas.

Em relação a influência dos óleos sobre a retenção da calda pulverizada em comparação com os surfactantes, em trabalho de Nalewaja (1995) cita-se que os herbicidas cyanazine, glyfosate e diclofop obtiveram melhor espalhamento na pulverização e retenção da solução da calda quando aplicados com óleos minerais ou vegetais do que com vários outros surfactantes.

Em trabalho que analisou o efeito de superficies foliares e efeito de surfactantes na atividade do herbicida sulfentrazone em diversas plantas, Dayan et al. (1996) obtiveram que todos os surfactantes utilizados no experimento aumentaram a absorção do sulfentrazone apesar de alguns aumentarem mais do que outros. Em relação a influência da superficie foliar, uma relação inversa entre absorção e quantidade de ceras cuticular foi detectada. Plantas com maior quantidade de ceras absorveram menor quantidade de sulfentrazone do que as espécies com menor quantidade de ceras em sua superficie foliar.

Além da presença ou não de tricomas, os padrões de ceras na superficie são extremamente importantes pois afetam o grau de umidade da superficie. A 
cera da superfície resiste ao umedecimento por pulverização, muito mais do que uma cutícula lisa. Deste modo, o grau de suscetibilidade da planta aos herbicidas pode depender da extensão do desenvolvimento dessa cera superficial e a ação seletiva dos herbicidas pode ser devido, em parte, à quantidade de cera superficial nas diferentes espécies (Cutter, 1986). Essa afirmação vem de encontro aos resultados demonstrados no experimento em relação ao grau de controle entre as três espécies, que demonstrou a maior suscetibilidade da espécie Sida cordifolia que apresentou cutícula mais plana e lisa, com ceras do tipo amorfa e do dificil controle das outras espécies com maiores quantidades de ceras superficiais e maior quantidade de tricomas como foi o caso da espécie Sida glaziovii.

Hess \& Falk (1990) observam que os tricomas podem interceptar as gotas da calda pulverizada antes que elas possam alcançar a superficie epidérmica, mesmo quando os tricomas são simples e a densidade de tricomas é baixa.

Em alguns experimentos o aumento da concentração dos adjuvantes faz com que essas limitações impostas pela superficie foliar sejam superadas. No entanto é necessário que se façam testes em cada situação para que se conheçam respostas especificas para cada espécie a ser controlada. 


\section{CONCLUSÕES}

Nas condições experimentais as quais foram conduzidas as avaliações, pode-se concluir que:

a) A Sida rhombifolia foi a espécie que apresentou maior quantidade de ceras epicuticulares do tipo estriada randômica, seguida pela Sida glaziovii e a espécie Sida cordifolia não apresentou ornamentação de cutícula mostrando uma superficie plana e lisa.

b) A espécie que apresentou maior quantidade de tricomas foi a Sida glaziovii, principalmente na superficie adaxial.

c) As três espécies apresentaram diversos tricomas do tipo estelar com até seis ramificações, tricomas simples sem ramificações e glandulares simples, curtos e longos. Também apresentaram estômatos do tipo anomocítico, distribuidos aleatoriamente na face superior (adaxial) e inferior (abaxial).

d) Não foi obtida interação significativa entre os fatores estudados, adjuvantes e herbicidas mas, obteve-se na média maiores notas de fitotoxicidade com fluroxipir + picloram na dose de $1,5 \mathrm{~L}$ p.c. ha $^{-1}$ nas três espécies analisadas.

e) $\mathrm{O}$ adjuvante que apresentou melhores notas de fitotoxicidade foi o surfactante organosiliconado Silwet nas espécies Sida rhombifolia e Sida glaziovii. 
f) Das três espécies presentes no experimento, a espécie que demonstrou maior sensibilidade aos tratamentos foi a espécie Sida cordifolia. 


\section{REFERÊNCIAS BIBLIOGRÁFICAS}

ANDERSON, P.W. Weed science: principles. New York: West Publ., 1977. cap. 7, p.303-321: Surfactants.

ANDREI, E. Compêndio de defensivos agrícolas: guia prático de produtos fitossanitários para uso agrícola. 6.ed. São Paulo: Organização Andrei, 1999. 672p.

BAKER, E.A. Chemistry and morphology of plant epicuticular waxes. In: CUTLER, D.F.; ALVIN, K.L.; PRICE, C.E. (Ed.) The plant cuticle. London: Academic Press, 1982. p.139-165.

BUKOVAC, M.J.; PETRACEK, P.D.; FADER, R.G.; MORSE, R.D. Sorption of organic compounds by plant cuticle. Weed Science, v.38, p.289-298, May 1990.

CAMARGO, P.N.; SILVA, O. Manual de adubação foliar. São Paulo: Editora Herba, 1975. 258p.

CONSTANTIN, J.; CONTIERO, R.L. Eficiência e fitotoxicidade do herbicida picloram, sal Tipa + fluroxipir mhe no controle de Eupatorium squalidum em pastagem. In: CONGRESSO BRASILEIRO DA CIÊNCIA DAS PLANTAS DANINHAS, 21., Caxambú, 1997. Resumos. Viçosa : SBCPD, 1997. p.297. 
CUTTER, E.G. Anatomia vegetal. São Paulo: Editora Roca, 1986. pt.1, 304p.

DAYAN, F.E,; GREEN, H.M.; WEETE, J.D.; HANCOK, H.G. Postemergence activity of Sulfentrazone: Effects of surfactants and leaf surfaces. Weed Science, v.44, p.797-803, 1996.

DEUBER, R Ciência das plantas daninhas: fundamentos. Jaboticabal: FUNEP, 1992. v.1, 431p.

DEVINE, M.D. Mechanisms of herbicide absorption and translocation in plants. Weed Science, v.38, p.279, 1990.

DEVINE, M.D.; BORN, W.H.V. Absortion and transport in plants. In: GROVER, R; CESSNA, A. J. Environmental chemistry of herbicides. Boca Raton: CRC Press, 1991. v.2, cap. 3, p.119-139.

DEVINE, M.D.; DUKE, S.O.; FEDTKE, C. Physiology of herbicide action. London: Prentice Hall, 1993. 441p.

DURIGAN, J. C. Efeitos de adjuvantes na aplicação e eficácia dos herbicidas. 2.ed. Jaboticabal: FUNEP, 1993. v.1, 42p.

DUTRA, I.S.; MARCHI, S.R. Efeito do herbicida Plenum no controle de Eupatorium squalidum em pastagem. In: CONGRESSO BRASILEIRO DA CIÊNCIA DAS PLANTAS DANINHAS, 21., Caxambú, 1997. Resumos. Viçosa: SBCPD, 1997. p.301. 
DUTRA, I.S.; MELHORANÇA, A.L. Avaliação da eficiência do herbicida Mannejo no controle de Senna obtusifolia e Sida rhombifolia em pastagem de Brachiaria brizanta. In: CONGRESSO BRASILEIRO DA CIÊNCIA DAS PLANTAS DANINHAS, 21., Caxambú, 1997. Resumos. Viçosa: SBCPD, 1997. p.302.

FEDKE, C. Biochemistry and physiology of herbicide action. Berlin: Springer Verlag, 1982. 202p.

FOY, C.L.; TAKENO, T. Effect of polisorbate surfactants with various hydrophilic- lipophilic balance ( HLB ) values on leaf surface ultrastructure and mobility of methazone in plants and soil. In: FOY, C.L. (Ed.) Adjuvants for agrichemicals. Boca Raton: CRC Press, $1992 . \quad$ cap. 14, p.169-185.

GASKIN, R.E. Effect of organosilicone surfactants on the foliar uptake of herbicides: stomatal infiltration versus cuticular penetration. In: INTERNATIONAL SYMPOSIUM ON ADJUVANTS FOR AGROCHEMICALS, 4., Melbourne, 1995. Proceedings. New Zealand: New Zealand Forest Research Institute, 1995. p.243-248.

GODDARD, E.D.; PADMANABHAN, K.P.A. A mechanistic study of the wetting, spreading, and solution properties of organosilicone surfactants. In: FOY, C.L. (Ed.) Adjuvants for agrichemicals. Boca Raton: CRC Press, 1992. cap.35, p.373-383.

GREEN, J.M. Specifying adjuvants for pesticides. In: INTERNATIONAL SYMPOSIUM ON ADJUVANTS FOR AGROCHEMICALS, 4., Melbourne, 1995. Proceedings. New Zealand: New Zealand Forest Research Institute, 1995. p.320-327. 
HARKER, K.N. Effects of various adjuvants on sethoxydim activity. Weed Technology, v.6, p.865-870, 1992.

HARR, J.; GUGGENHEIM, R; SCHULKE, G.; FALK, R. H. The leaf surface of major weeds. Witterswil: Sandoz Agro, 1991. 133p.

HESS, F.D. Herbicide absortion and translocation and their relantionship to plant tolerances and suscebility. In: DUKE, S.O. Weed physiology. 2.ed. Boca Raton: CRC Press, 1985. v.2, p.192-214.

HESS, F.D. Herbicide action: an intensive course on activity, selectivity, behavior, fate herbicides in plants and the environment. Indiana: Purdue University, 1996a. p. 56-74: Absortion.

HESS, F.D. Herbicide action: an intensive course on activity, selectivity, behavior, fate herbicides in plants and the environment. Indiana: Purdue University, 1996b. p.75-96: Adjuvants.

HESS, F.D.; FALK K.H. Herbicide deposition on leaf surfaces. Weed Science, v.38, p.280-288, May 1990.

HOLLOWAY, P.J. Structure and histochemistry of plant cuticular membranes: an overview. In: CUTLER, D.F.; ALVIN, K.L.; PRICE, C.E. (Ed.) The plant cuticle. London: Academic Press, 1982. p.1-32.

HOLLOWAY, P.J. Structure and chemistry of plant cuticles. Pesticide Science, v.37, p.203-206, 1993.

HULL, H.M.; DAVIS, D.G.; STOLZENBERG, G.E. Action of adjuvants on plant surfaces. In: WEED SCIENCE SOCIETY OF AMERICA. Adjuvants for herbicides. Champaign, 1982. cap.3, p.26-67. 
KIRKWOOD, R.C. Target sites for herbicide action. New York: Plenum Press, 1991. 339p. (Topics in Applied Chemistry).

KIRKWOOD, R. C. Use and mode of action of adjuvants for herbicides: A review of some current work. Pesticide Science, v.38, p.93-102, 1993.

KIRKWOOD, R. C.; KNIGHT, H.; McKAY, I.; CHANDRASENA, J.P.N.R. The effect of a range of nonyphenol surfactants on cuticle penetration, absortion and translocation of water-soluble and non-water-soluble. . In: FOY, C.L. (Ed.). Adjuvants for agrichemicals. Boca Raton: CRC Press, 1992. p.117-126.

KISSMANN, K. Adjuvantes para caldas de produtos fitossanitários. São Paulo: BASF, 1999. 29p.

KISSMANN, K. G.; GROTH, D. Plantas infestantes e nocivas. São Paulo: BASF, 1995. t.3, 683p.

KNOCHE, M. Organosilicone surfactant performance in agricultural spray application: a review. Weed Research, v.34, p.221-239, 1994.

KNOCHE, M.; BUCOVAC, M.J. Interaction of surfactant and leaf surface in glyphosate absortion. Weed Science, v.41, p.87-93, 1993.

MARTINS, C.C.; MENDONÇA, C.G.; MARTINS, D.; VELINI, V. Superação da dormência de sementes de carrapicho-beiço-de-boi. Planta Daninha, v.15, n.2, p.104-113, 1997.

MATUO, T.; NAKAMURA, S.H.; ALMEIDA, A. Efeitos de alguns adjuvantes da pulverização nas propriedades físicas do líquido. Summa Phytopathologica, v.15, p.163-173, 1989. 
MAUSETH, J.D. Plant anatomy. Menlo Park: Benjamin/Cummings Publ., 1988. 560p.

METCALFE, C. R.; CHALK, L. Anatomy of the dicotyledons. 2.ed. Oxford: Claredon Press, 1979. v.1, 276p.

NALEWAJA, J.D. Behavior, applicability and efficacy of non-surfactant adjuvants. In: INTERNATIONAL SYMPOSIUM ON ADJUVANTS FOR AGROCHEMICALS, 4., Melbourne, 1995. Proceedings. New Zealand: New Zealand Forest Research Institute, 1995. p.186-192.

NALEWAJA, J. D.; MATYSIAK, R.; FREEMAN, T. Spray droplet residual of glyphosate in various carriers. Weed Science, v.40, p.576-589, 1992.

PRICE, C.E. A review of the factors influencing the penetration of pesticides through plant leaves. In: CUTLER, D.F. ; ALVIN, K.L. ; PRICE, C.E. (Ed.) The plant cuticle. London: Academic Press, 1982. p.237-252.

PRICE, C.E.; ANDERSON, N.H. Uptake of chemicals from foliar deposits: effects of plant species and molecular structure. Pesticide Science, v.16, p.369-377, 1985.

RICOTTA, J.A.; MASIUNAS, J.B. Relantionship of leaf surface characteristics to acifluorfen tolerance in tomato (Lycopersicon esculentum) and related species. Weed Science, v.40, p.402-407, 1992.

RODRIGUES, B.N.; ALMEIDA, F.S. Guia de herbicidas. 4.ed. Londrina: B.N. Rodrigues, 1998. 648p. 
RUTTER, H.D.; UFFING, A.J.M.; MEINEN, E.; PRINS, A. Influence of surfactants and plant species on leaf retention of spray solutions. Weed Science, v.38, p.567-572, 1990.

SALAS PINO, P.A.G. Efeito de adjuvantes, volume de calda e qualidade da água na eficácia do herbicida glyfosate. Piracicaba, 1996. 79p. Dissertação (Mestrado) - Escola Superior de Agricultura "Luiz de Queiroz", Universidade de São Paulo.

SOLEREDER, H. Systematic anatomy of the dicotyledon. Oxford: Claredon Press, 1908. v.1, 644p.

STEVENS, P.J.G. Organosilicone surfactants as adjuvants for agrochemicals. Pesticide Science, v.38, p.103-122, 1993.

STEVENS, P.J.G.; BAKER, E.A. Factors affecting the foliar absortion and redistribuition of pesticides. 1. Properties of leaf surfaces and their interactions with spray droplets. Pesticide Science, v.19, p.265-281, 1987.

STEVENS, P.J.G. ; BUCOVAC, M.J. Studies on octylphenoxy surfactants.

Part 2: Effects on foliar uptake and translocation. Pesticide Science, v.20, p.37-52, 1987.

SUN, J.; FOY, C.L. Structurally related organosilicone surfactants, their physical-chemical properties and effects on uptake and efficacy of primisulfuron in velvetleaf (Abutilon theophrasti medicus). In: INTERNATIONAL SYMPOSIUM ON ADJUVANTS FOR AGROCHEMICALS, 4., Melbourne, 1995. Proceedings New Zealand: New Zealand Forest Research Institute, 1995. p.225-230. 
VAN VALKENBURG, J.W. Terminology, classification and chemistry. In: WEED SCIENCE SOCIETY OF AMERICA. Adjuvants for herbicides. Champaign, 1982. cap.1, p.1-9.

VELINI, E. D.; TRINDADE, M.L.B. Comportamento de herbicidas na planta. Época de aplicação de herbicidas In: SIMPÓSIO NACIONAL SOBRE MANEJO INTEGRADO DE PLANTAS DANINHAS EM HORTALIÇAS, Botucatu, 1992. Anais. Botucatu: s.ed., 1992. p.65-85.

VICTORIA FLLHO, R.; LADEIRA NETO, A. Efeito de misturas de fluroxipir + picloram no controle de Vernonia polyanthes em pastagens com aplicação costal. In: CONGRESSO BRASILEIRO DA CIÊNCIA DAS PLANTAS DANINHAS. 21., Caxambú, 1997. Resumos. Viçosa: SBCPD, 1997a. p.322.

VICTORIA FILHO, R; LADEIRA NETO, A. Efeito de misturas de 2,4-D no controle de plantas daninhas em pastagens com aplicação em área total. In: CONGRESSO BRASILEIRO DA CIÊNCIA DAS PLANTAS DANINHAS, 21., Caxambú, 1997. Resumos. Viçosa : SBCPD, 1997b. p.323.

VIDAL, R.A. Herbicidas: mecanismos de ação e resistência de plantas. Porto Alegre: Pallotti, 1997. 165p. 


\section{APÊNDICE}


Tabela 1A - Resumo da análise de variância para as quatro avaliações (notas) espécie Sida rhombifolia

\begin{tabular}{cccccc}
\hline & & \multicolumn{4}{c}{ Quadrados médios } \\
\cline { 3 - 6 } CV & GL & $1^{\text {a }}$ avaliação & $2^{\text {a }}$ avaliação & $3^{\mathbf{a}}$ avaliação & $4^{a}$ avaliação \\
\hline Tratamentos & 24 & 0,2018 & 0,2177 & 0,3288 & 0,4406 \\
& & $(0,00001)$ & $(0,00001)$ & $(0,00001)$ & $(0,00001)$ \\
Blocos & 3 & 0,0423 & 0,0189 & 0,1721 & 0,0643 \\
& & $(0,1332)$ & $(0,2321)$ & $(0,00002)$ & $(0,0064)$ \\
Resíduo & 72 & 0,0220 & 0,0130 & 0,0145 & 0,0144 \\
\hline
\end{tabular}

Tabela 2A - Resumo da análise de variância para as quatro avaliações (notas) espécie Sida glaziovii

\begin{tabular}{lccccc}
\hline & & \multicolumn{4}{c}{ Quadrados médios } \\
\cline { 3 - 6 } CV & GL & $1^{\mathrm{a}}$ avaliação & $2^{\mathrm{a}}$ avaliação & $3^{\mathrm{a}}$ avaliação & $4^{\mathrm{a}}$ avaliação \\
\hline Tratamentos & 24 & 0,2588 & 0,4088 & 0,5770 & 0,5325 \\
& & $(0,00001)$ & $(0,00001)$ & $(0,00001)$ & $(0,00001)$ \\
Blocos & 3 & 0,0569 & 0,1128 & 0,0346 & 0,0254 \\
& & $(0,01815)$ & $(0.01003)$ & $(0,21396)$ & $(0,00902)$ \\
Resíduo & 72 & 0,0160 & 0,0277 & 0,0226 & 0,0061 \\
\hline
\end{tabular}

Tabela 3A - Resumo da análise de variância para as quatro avaliações (notas) espécie Sida cordifolia

\begin{tabular}{lccccc}
\hline & & \multicolumn{4}{c}{ Quadrados médios } \\
\cline { 3 - 6 } CV & GL & $1^{\mathrm{a}}$ avaliação & $2^{\mathrm{a}}$ avaliação & $3^{\mathrm{a}}$ avaliação & $4^{\mathrm{a}}$ avaliação \\
\hline Tratamentos & 24 & 0,3026 & 0,4599 & 0,6116 & 0,6383 \\
& & $(0,00001)$ & $(0,00001)$ & $(0,00001)$ & $(0,00001)$ \\
Blocos & 3 & 0,0190 & 0,0042 & 0,0066 & 0,0025 \\
& & $(0,33667)$ & $(0,82259)$ & $(0,58249)$ & $(0,16142)$ \\
Resíduo & 72 & 0,0166 & 0,0138 & 0,0099 & 0,0014 \\
\hline
\end{tabular}


Tabela 4A - Resumo da análise de variância para as quatro avaliações (notas) da espécie Sida rhombifolia

\begin{tabular}{lccccc}
\hline CV & GL & \multicolumn{4}{c}{ Quadrados médios } \\
\cline { 3 - 6 } & & $1^{\mathrm{a}}$ avaliação & $2^{\mathrm{a}}$ avaliação & $3^{\mathrm{a}}$ avaliação & $4^{\mathrm{a}}$ avaliação \\
\hline Herbicidas & 5 & 0,1324 & 0,1229 & 0,1412 & 0,1190 \\
& & $(0,00032)$ & $(0,00002)$ & $(0,00001)$ & $(0,00004)$ \\
Adjuvantes & 3 & 0,1130 & 0,0619 & 0,0247 & 0,0617 \\
& & $(0,00405)$ & $(0,00577)$ & $(0,18272)$ & $(0,00940)$ \\
H x A & 15 & 0,0406 & 0,0176 & 0,0188 & 0,0160 \\
& & $(0,05735)$ & $(0,22541)$ & $(0,24885)$ & $(0,39831)$ \\
Blocos & 3 & 0,0440 & 0,0197 & 0,1792 & 0,0670 \\
& & $(0,13323)$ & $(0,23228)$ & $(0,00002)$ & $(0,00637)$ \\
Resíduo & 69 & 0,0230 & 0,0135 & 0,0149 & 0,0149 \\
\hline Total & 95 & \multicolumn{5}{c}{} \\
\hline
\end{tabular}

Tabela 5A - Resumo da análise de variância para as quatro avaliações (notas) da espécie Sida glaziovii

\begin{tabular}{lccccc}
\hline CV & GL & \multicolumn{5}{c}{ Quadrados médios } \\
\cline { 3 - 6 } & & $1^{\text {a }}$ avaliação & $2^{\text {a }}$ avaliação & $3^{\text {a }}$ avaliação & $4^{a}$ avaliação \\
\hline Herbicidas & 5 & 0,3908 & 0,4955 & 0,3369 & 0,0481 \\
& & $(0,00001)$ & $(0,00001)$ & $(0,00001)$ & $(0,00005)$ \\
Adjuvantes & 3 & 0,0686 & 0,0656 & 0,0374 & 0,0208 \\
& & $(0,00947)$ & $(0,08502)$ & $(0,19892)$ & $(0,02516)$ \\
H x A & 15 & 0,0115 & 0,0249 & 0,0139 & 0,0076 \\
& & $(0,78116)$ & $(0,60213)$ & $(0,87235)$ & $(0,29420)$ \\
Blocos & 3 & 0,0592 & 0,1174 & 0,0360 & 0,0264 \\
& & $(0,01804)$ & $(0,00994)$ & $(0,21401)$ & $(0,00895)$ \\
Residuo & 69 & 0,0166 & 0,0287 & 0,0236 & 0,0063 \\
\hline Total & 95 & \multicolumn{5}{c}{} \\
\hline
\end{tabular}


Tabela 6A - Resumo da análise de variância para as quatro avaliações (notas) da espécie Sida cordifolia

\begin{tabular}{lccccc}
\hline CV & GL & \multicolumn{4}{c}{ Quadrados médios } \\
\cline { 3 - 5 } & & $1^{\text {a }}$ avaliação & $2^{a}$ avaliação & $3^{a}$ avaliação & $4^{\text {a }}$ avaliação* \\
\hline Herbicidas & 5 & 0,1091 & 0,1156 & 0,0503 & - \\
& & $(0,00017)$ & $(0,00003)$ & $(0,00069)$ & \\
Adjuvantes & 3 & 0,0026 & 0,0071 & 0,0016 & - \\
& & $(0,92669)$ & $(0,69198)$ & $(0,92099)$ & - \\
Hx A & 15 & 0,0114 & 0,0104 & 0,0057 & - \\
Blocos & & $(0,81389)$ & $(0,75601)$ & $(0,87812)$ & - \\
Resíduo & 3 & 0,0198 & 0,0044 & 0,0111 & \\
\hline Total & & $(0,33693)$ & $(0,82275)$ & $(0,34090)$ & \\
\hline
\end{tabular}

* Notas todas iguais $(9,0)$ não apresentaram variância.

Tabela 7A - Resumo da análise de variância do peso fresco e seco das três espécies de Sida spp. utilizadas

\begin{tabular}{lccccccc}
\hline & \multicolumn{6}{c}{ Quadrados médios } \\
\cline { 3 - 8 } & GL & \multicolumn{5}{c}{ Matéria fresca } & Matéria seca \\
\cline { 3 - 8 } Herbicidas & 5 & 0,5436 & 0,9931 & 0,0934 & 0,0492 & 0,1977 & 0,0215 \\
& & $(0,00042)$ & $(0,00001)$ & $(0,04011)$ & $(0,04967)$ & $(0,00008)$ & $(0,41245)$ \\
Adjuvantes & 3 & 0,1847 & 0,0914 & 0,0072 & 0,0174 & 0,0331 & 0,0087 \\
& & $(0,13895)$ & $(0,39438)$ & $(0,90238)$ & $(0,51503)$ & $(0,32266)$ & $(0,74884)$ \\
Hx A & 15 & 0,0637 & 0,0630 & 0,0630 & 0,0121 & 0,0297 & 0,0247 \\
& & $(0,82266)$ & $(0,77942)$ & $(0,07906)$ & $(0,88454)$ & $(0,44033)$ & $(0,31231)$ \\
Blocos & 3 & 0,9918 & 1,0575 & 0,2940 & 0,2324 & 0,3453 & 0,2174 \\
& & $(0,00006)$ & $(0,00003)$ & $(0,00031)$ & $(0,00004)$ & $(0,00002)$ & $(0,00006)$ \\
Resíduo & 69 & 0,0980 & 0,0905 & 0,0378 & 0,0210 & 0,0280 & 0,0211 \\
\hline \multirow{2}{*}{ Total } & 95 & \multicolumn{7}{c}{ S.glaziovii } & S.cordifolia & S.rhombifolia & S.glaziovii & S.cordifolia \\
\hline
\end{tabular}


Tabela 8A - Resumo da análise de variância do peso fresco e seco das três espécies de Sida spp. utilizadas

\begin{tabular}{|c|c|c|c|c|c|c|c|}
\hline & \multirow[b]{3}{*}{ GL } & \multicolumn{6}{|c|}{ Quadrados médios } \\
\hline & & \multicolumn{3}{|c|}{ Matéria fresca } & \multicolumn{3}{|c|}{ Matéria seca } \\
\hline & & S.rhombifolia & S.glaziovii & S.cordifolia & S.rhombifolia & S.glaziovii & S.cordifolia \\
\hline \multirow[t]{2}{*}{ Tratamentos } & 24 & 0,3979 & 0,5939 & 0,6664 & 0,1090 & 0,1473 & 0,0749 \\
\hline & & $(0,00002)$ & $(0,00001)$ & $(0,00001)$ & $(0,00001)$ & $(0,00001)$ & $(0,00284)$ \\
\hline \multirow[t]{2}{*}{ Blocos } & 3 & 0,9620 & 1,0410 & 0,3681 & 0,2398 & 0,3687 & 0,2517 \\
\hline & & $(0,00007)$ & $(0,00003)$ & $(0,00014)$ & $(0,00003)$ & $(0,0001)$ & $(0,00026)$ \\
\hline Resíduo & 72 & 0,0965 & 0,0903 & 0,0416 & 0,0206 & 0,0271 & \\
\hline
\end{tabular}

